\title{
Critérios utilizados por trabalhadores para a inclusão de adolescentes em serviços públicos de saúde mental
}

\author{
Natália Areias Gomes
}

Dissertação apresentada ao Programa de PósGraduação em Saúde Pública para a obtenção do título de Mestre em Saúde Pública.

Área de concentração: Saúde materno-infantil

Orientador: Prof ${ }^{a}$. Titular Néia Schor

São Paulo 2009 
É expressamente proibida a comercialização deste documento, tanto na sua forma impressa como eletrônica. Sua reprodução total ou parcial é permitida exclusivamente para fins acadêmicos e científicos, desde que na reprodução figure a identificação do autor, título, instituição e ano da tese/dissertação. 
Aos meus queridos pais. Através de suas histórias de vida e do dispêndio incansável de afeto me ensinaram a acreditar no sentido do que se faz e no fazer para dar sentido. 


\section{AGRADECIMENTOS}

Agradeço aos trabalhadores de saúde mental que de forma generosa compartilharam suas histórias e suas idéias. Sem eles este trabalho não seria possível e tampouco teria sentido realizá-lo.

À CAPES pela bolsa de estudos disponibilizada, que me permitiu custear e realizar este estudo

À minha orientadora Profa. Dra. Néia Schor, que me guiou pela difícil tarefa de organizar os pensamentos e as palavras, entendendo que fazer pesquisa, além de nos fazer crescer, também é compartilhar e destinar conhecimento ao outro.

Ao Prof. Dr. Alberto Olavo Advincula Reis, que com seu olhar apurado e sensível pôde ler aquilo que eu ainda não sabia escrever. Com ele pude entender que não existe obra, nem autor, sem público.

À Profa. Dra. Maria Cristina Gonçalves Vicentin, por suas contribuições igualmente pertinentes e cuidadosas que trouxeram novos rumos a este trabalho.

Aos colegas e amigos do Laboratório de Saúde Mental Coletiva, pela possibilidade de troca e de discussão de temas tão nodosos.

Às queridas amigas e companheiras de mestrado Alina Zoqui, Caroline Dombi, Caroline Geocze, Grace Peixoto e Patrícia Delfini. Não fosse os papos no jardim, o desespero dos prazos compartilhado, as comemorações às conquistas e tantas outras trocas, não teria sido nada divertido.

Ao meu amigo siamês André Farias. É por segui-lo e por me seguir que chegamos quase sempre ao mesmo lugar. Que sigamos sempre juntos por muitas aventuras. 
Às preciosas amigas Ana Claudia D’Angioli, Ivana Bilange e Sharon Dayan (eu ainda não sei escrever seu novo nome), pelo apoio acolhedor e compreensivo, mesmo nos meus maiores momentos de ausência.

À minha grande família mineira. Para mim o termo "acolhimento" nasceu na casa da vó Maria, pois ainda que distantes, ainda que muitos, ainda que diferentes... não há laço mais forte e mais intenso do que ser um punhado de Areias.

Aos meus irmãos Nádia, Carlinhos e Alê. Pela companhia de toda vida, pelo apoio infindável, pelo afeto que transborda sem nunca caber... Que possamos sempre dividir conquistas pela vida afora.

Mais uma vez aos meus pais. Por lerem o que eu escrevo mesmo sem entender do que se trata, pela rotina de pesquisa que inundou a casa, pelo carinho nos momentos de angústia, enfim, por manterem o mundo preso aos meus pés para que eu pudesse me lançar ao universo. 


\section{RESUMO}

GOMES NA. Critérios utilizados por trabalhadores para a inclusão de adolescentes em serviços públicos de saúde mental. São Paulo; 2009. [Dissertação de mestrado Faculdade de Saúde Pública da USP]

O objetivo do presente trabalho foi o de compreender a natureza dos critérios que norteiam a inclusão de adolescentes em serviços de atenção à saúde mental do sistema público de saúde. Para tanto o conceito de saúde mental foi contextualizado assim como suas perspectivas no campo da saúde pública enquanto modelo de atenção disponível à população e as principais mudanças em processo a partir da década de 70 com a reforma psiquiátrica. Em seguida foi apresentado um exame das particularidades da saúde mental do adolescente e as características das políticas e dos modelos de atenção previstos para atender a suas necessidades. A idéia que orientou a investigação quanto ao acesso de adolescentes aos serviços de saúde mental se pauta principalmente no papel do trabalhador incumbido de decidir sobre seu destino na instituição e na prática do acolhimento enquanto forma singular de receber, compreender e relacionar-se com a clientela. Foram realizadas entrevistas semi-dirigidas com 28 trabalhadores que atuam na inclusão de novos usuários nos serviços de atenção à saúde mental para adolescentes no município de São Paulo (especificamente na região oeste, que compreende os distritos de saúde Butantã, Lapa e Pinheiros), sendo posteriormente submetidas à análise de discurso. Percebe-se pelo discurso dos trabalhadores que os critérios de inclusão no serviço são complexos e na maior parte das vezes causam dúvida quanto a sua indicação precisa. Em meio ao processo de decisão destacam-se os meios técnicos que o trabalhador possui para a eficácia de sua prática e para a estruturação subjetiva frente ao seu trabalho, tendo em vista que tais aspectos permitem maior ou menor abertura às inúmeras possibilidades de queixas que possam surgir como demanda ao serviço em que trabalha. Também se observam dificuldades no emprego da estratégia do acolhimento como prática de recepção por sua característica de imprevisibilidade que propõe atender à demanda no momento em que ela é sentida como urgente pelo usuário, fugindo à lógica da triagem agendada e das filas de espera. Quanto às questões referidas como principais critérios de inclusão destacam-se as urgências (e seus maiores representantes são os casos de tentativa de suicídio), a relação com as instituições que fazem o encaminhamento, as características e condições do serviço, a gravidade do caso e a organização da rede de atenção. Uma vez evidenciados os principais aspectos envolvidos na decisão do trabalhador sobre a inclusão do adolescente no serviço, discutiu-se, finalmente, um possível desencontro entre a lógica do adolescente e a lógica de funcionamento das instituições de saúde, o que muitas vezes impossibilita o reconhecimento dos serviços de saúde mental por parte dos adolescentes como recursos possíveis aos quais possam recorrer em caso de necessidade, gerando inclusive a escassez da procura.

PALAVRAS-CHAVES: acolhimento, adolescência, inclusão, saúde mental, saúde pública. 


\section{SUMMARY}

GOMES NA. Criterions used by workers for the inclusion of adolescents in public mental health. São Paulo; 2009. [Essay of Master's Degree - University of Public Health of USP]

The aim of this involved study was to understand the nature of the criterions governing the inclusion of adolescents in care services to mental health of the public health system. Thus the concept of mental health was contextualized and its prospects in the field of public health as a model of available care to the population and the main changes in process from the 70's with the psychiatric reform. Afterwards was reported a special screening of mental health of adolescents and the characteristics of politics and models of predict care to attend their needs. The idea that guided the research on the access of adolescents to mental health services is based mainly on the role of the worker responsible for deciding on their fate in the institution and practice of the reception as a singular way to receive, understand and relate to the costumer. It was performed semi-directed interviews with 28 employees that work in the inclusion of the new service users in mental health care for adolescents in São Paulo municipality (specifically in the western region, which comprises the districts of health Butantã, Lapa and Pinheiros), and then subsequently subjected to analysis of speech. It is perceived by the speech of employees that the criterions for inclusion in service are complex and most often cause doubt as to its precise indication. Amid the process of decision there are technical means that the employee has to the effectiveness of their practice and the subjective structuring front of your work, in order to allow bigger or smaller opening to endless possibilities of complaints that may appear as demand to the service that they work. Also observed difficulties in the employment strategy of the reception as a practice for approval by its characteristic unpredictability which proposes to attend the demand at the moment it is perceived as urgent by the user, running the logic of the scheduled screening and the waiting lines. The questions referred to as main criterions for inclusion in the emergency stand out (and their representatives are more cases of suicide attempt), the relationship with institutions that do the routing, the characteristics, and conditions of service, the severity of the case and organization of the network of care. Once highlighted the main aspects of the worker involved in the decision of the inclusion of the adolescents in the service, is discussed, finally, a possible mismatch between the logic of the adolescents and the logic of the functioning of health institutions which often impossibilities the recognition of mental health service by the adolescents as possible resources to which to use in case of need, including creating a shortage of demand.

KEY WORDS: Reception, Adolescence, Inclusion, Mental health, Public health. 


\section{ÍNDICE}

\section{INTRODUÇÃO}

O CAMINHO AO TEMA DA PESQUISA …............................................... 11

SAÚDE MENTAL NO CAMPO DA SAÚDE PÚBLICA BRASILEIRA ........... 15

ADOLESCÊNCIA E SAÚDE MENTAL

Percorrendo o(s) Conceito(s) de Adolescência..............................................22

O Discurso das Políticas de Atenção à Saúde do Adolescente........................298

OS DESAFIOS NA CONSTRUÇÃO DE UM NOVO MODO DE RECEBER OS QUE CHEGAM

Modalidades de Atenção e suas Perspectivas .................................................... 34

O Trabalhador de Saúde Mental e a Tarefa de Discernir ................................. 40

Necessidade e Demanda às Portas dos Serviços ............................................ 42

A Prática do Acolhimento e a Questão do Acesso............................................47

\section{CONSIDERAÇÕES METODOLÓGICAS}

OBJETIVO E OBSERVAÇÕES SOBRE O MÉTODO …..................................53

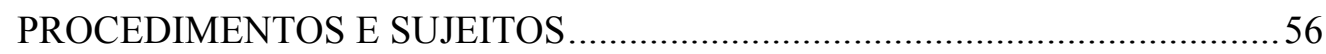

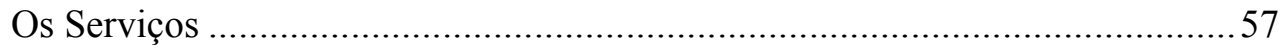

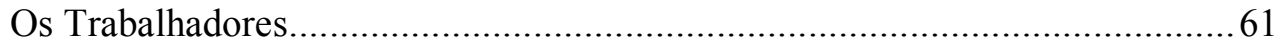

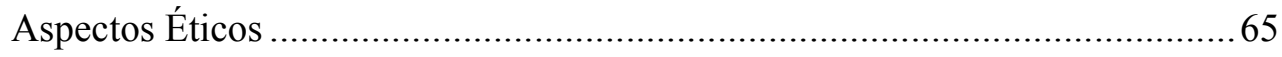

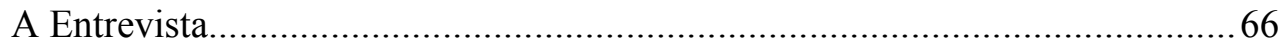

\section{PROCESSO DE ANÁLISE}

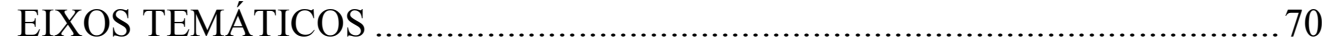

História Profissional e Trajetória na Saúde Mental........................................ 71

O Processo de Entrada de Adolescentes na Unidade ......................................82 82

Os Critérios Utilizados para a Inclusão de Adolescentes no Serviço............... 104

Caracterização do Trabalho em Equipe na Unidade e o Papel Atribuído a ela na

Decisão sobre a Seleção da Clientela ......................................................... 114

Função das Políticas que Caracterizam o Serviço na Decisão sobre a Inclusão118

Caracterização do Acolhimento .............................................................. 124

Reflexões sobre a Ausência de Adolescentes nos Serviços de Saúde.............. 130

\section{DISCUSSÃO}

FORMAÇÃO E TRABALHO “EM REFORMA”.......................................... 138

REFLEXÕES SOBRE A PRÁTICA DO ACOLHIMENTO............................ 145

CONSIDERAÇÕES FINAIS ......................................................................150

REFERÊNCIAS BIBLIOGRÁFICAS.......................................................157 


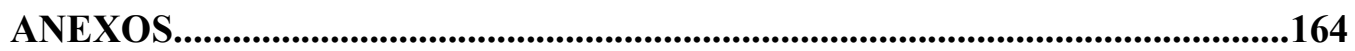

ANEXO 1 - TERMO DE CONSENTIMENTO LIVRE E ESCLARECIDO

ANEXO 2 - PARECER DO COMITÊ DE ÉTICA EM PESQUISA DA SERCRETARIA MUNICIPAL DE SAÚDE DE SÃO PAULO

ANEXO 3 - PARECER DO COMITÊ DE ÉTICA EM PESQUISA DA FACULDADE DE SAÚDE PÚBLICA DA USP 
INTRODUÇÃO 


\section{O CAMINHO AO TEMA DA PESQUISA}

A proposta inicial deste trabalho de pesquisa surgiu como produto da experiência vivida em serviços de saúde mental da rede pública de São Paulo desde a graduação no curso de psicologia.

Ainda no último ano de graduação, através de um programa de estágio oferecido pela prefeitura de São Paulo em parceria com o CIEE (Centro de Integração Empresa-Escola), pude conhecer o funcionamento do então recém nomeado CAPS (Centro de Atenção Psicossocial), estágio que durou o ano inteiro de 2003.

$\mathrm{Na}$ ocasião do meu ingresso, a unidade ainda se chamava Hospital-Dia (HD) em Saúde Mental para adultos e contava com cerca de 30 pacientes que freqüentavam o serviço, em sua maioria, diariamente. Poucos meses depois pude acompanhar a mudança de denominação, funcionamento e estrutura daquela unidade, que passou a se chamar Centro de Atenção Psicossocial (CAPS).

Naquela época eu pouco sabia sobre as "reformas" que estavam acontecendo no campo da saúde e em especial no campo da saúde mental, pois muitas universidades ainda não haviam incluído em seus currículos as mudanças que estavam acontecendo ao nosso redor.

O começo foi difícil e assustador, ainda mais se considerarmos que a única aproximação que tínhamos de instituições de saúde mental durante a graduação era a visita a hospitais psiquiátricos fechados, que freqüentávamos em determinado estágio do curso, com o objetivo de estudar psicopatologia "in loco" (ou em loucos) através de conversas entre 30 alunos e um paciente. 
Posso dizer que a experiência de trabalho no recém inaugurado CAPS influenciou fortemente minha formação e minhas escolhas posteriores pelo campo da saúde pública, o que me levou, depois de formada, a ingressar em um programa de aprimoramento profissional (PAP) financiado e gerido pela Fundação do Desenvolvimento Administrativo (FUNDAP) com duração de dois anos na área de "psicologia em Unidade Básica de Saúde". Com isso passei dois anos trabalhando como psicóloga em aprimoramento dentro de um Centro de Saúde ligado à Faculdade de Saúde Pública da Universidade de São Paulo e ao governo do Estado.

Nesses dois anos de aprimoramento pude resgatar algumas questões que se colocavam para mim quanto à prática de um trabalhador de saúde mental desde a graduação e a experiência no CAPS, dúvidas que partiam da construção do diagnóstico ao manejo e condução dos casos para que algo fosse de fato produzido enquanto assistência àqueles que buscavam tal serviço.

Como parte do programa de aprimoramento, participávamos da recepção aos novos usuários, seja através de grupos de triagem (realizados uma vez ao mês com o intuito de receber aqueles que se inscreviam para atendimento em saúde mental), seja por atendimentos de plantão, caracterizados pela disponibilização de um período por semana para acolher aqueles que chegavam ao serviço sem um agendamento prévio, por procura espontânea ou encaminhamento de outros profissionais.

Destaco algumas palavras neste texto inicial, pois foi justamente com base nas dúvidas e angústias frente a elas, enquanto aspectos do trabalho que desejava apreender, que decidi me debruçar, curiosa sobre o entendimento das primeiras queixas que traziam as pessoas ao serviço de saúde mental da unidade em questão e cheia de dúvidas quanto ao que fazer com elas, como encaminhá-las.

Muitas vezes esse pedido não era feito pela própria pessoa, mas pela equipe técnica de outros programas, como a saúde da mulher, da criança, do adolescente, etc. Assim, outro profissional julgava ser necessário que o paciente em questão falasse de seu "problema" a alguém com uma formação "psi”. Também nestes casos, algo me saltava aos ouvidos, pois me interessava pensar sob quais critérios esse 
profissional considerava a demanda do paciente e então lhe fazia tal encaminhamento.

Para além das dúvidas e da vontade de aprender sobre as questões técnicas do acolhimento à demanda, também comecei a perceber que as pessoas que chegavam ao serviço vinham com um discurso comum, fazendo referência a sintomas somáticos ou nomeando seu mal estar com nomenclaturas diagnósticas do campo da psiquiatria, o que esperavam que eu confirmasse e lhes dissesse o que eles significavam. No decorrer dos primeiros encontros, tomava como parte da tarefa mostrar à pessoa que ali o nosso papo era outro, eu estava ali para escutá-lo em seu sofrimento, não para categorizar seus sintomas ou the orientar sobre um possível diagnóstico. Então formulei uma primeira pergunta: com que expectativa as pessoas se dirigem ao trabalhador de saúde mental?

Hoje eu traduziria essa primeira pergunta como a construção de uma hipótese, a hipótese de que exista um roteiro pré-estabelecido de falas com as quais as pessoas se dirigem aos trabalhadores da área da saúde - principalmente quando estão dentro de uma instituição médica, como é o caso da imagem de uma Unidade Básica - com a expectativa de que seja aquilo que o profissional deseja ouvir, aquilo que deve ser dito para possibilitar a escuta.

Depois desse primeiro momento de escuta às queixas que as pessoas traziam ao serviço, outra tarefa era de extrema importância e causava ainda mais dúvidas, a partir das quais formulei uma segunda pergunta: como definir ao certo quem necessita mais ou menos de atenção em um serviço de saúde mental, tendo em vista nossa limitação de espaço e de recursos humanos? E como saber quem deve ficar nesta unidade e quem deve ser encaminhado para outra? E se for esse o caso, para qual?

Em meio às minhas próprias questões como profissional que estava iniciando na prática dos serviços de saúde, formulei perguntas que não tinham mesmo respostas fáceis e que também faziam parte do dia-a-dia de trabalhadores que, diferente de mim, trabalhavam há muito tempo em serviços de saúde mental. 
Tais questões ainda se tornavam mais complicadas quando considerávamos as queixas de crianças e adolescentes, pois nesses casos eles comumente eram representados por outros que falavam por eles, sejam pais ou responsáveis de outra natureza. As crianças não eram nem mesmo convidadas a virem no primeiro encontro, pois a estes outros era dada a função de falar sobre o sintoma, mas os adolescentes podiam participar se assim o desejassem.

Durante essa experiência percebi que poucos adolescentes escolhiam falar por si, poucos chegavam ao serviço por vontade própria e quando chegavam causavam surpresa e muitas vezes dúvida sobre como entender suas dúvidas ou seu pedido por cuidados.

Tendo em vista essas ricas experiências e a bagagem de perguntas que elas deixaram, assim se constituiu mais essa pergunta, agora dirigida ao programa de pósgraduação em Saúde Pública, e da qual faço motor para a construção de algum saber que, espero, possa auxiliar aqueles que continuam recebendo tais pedidos e que muitas vezes não sabem o que fazer com eles. Hoje, depois de alguns passos dados, a pergunta assim se coloca: como profissionais de serviços públicos de saúde mental utilizam elou (re) elaboram critérios para a inclusão de adolescentes nas diferentes modalidades de programas? 


\section{SAÚDE MENTAL NO CAMPO DA SAÚDE PÚBLICA BRASILEIRA}

Para responder às perguntas que norteiam esse trabalho de pesquisa, faz-se necessário percorrer alguns conceitos que se constituem como estruturantes do problema em questão. Um desses conceitos é o de saúde mental, tendo em vista que ele designa o campo onde este trabalho está inserido e define um tipo específico de saúde sobre o qual se delimita este campo.

A palavra saúde é definida no dicionário como "estado daquele cujas funções orgânicas, físicas e mentais se acham em situação normal" (FERREIRA, 1980, p. 1535), o que nos coloca diante da tarefa de definir, para discutirmos o conceito de saúde mental, o que vem a ser uma situação normal, ou o que podemos chamar de normalidade no que se refere à questão da saúde mental.

Georges Canguilhem inicia sua obra "O normal e o patológico" (1978) com a seguinte pergunta: "Seria o estado patológico apenas uma modificação quantitativa do estado normal?" (p. 19), e para respondê-la, percorre os caminhos da filosofia e da ciência. No entanto, neste momento nos parece suficiente retomar a idéia, também exposta no inicio de tal obra, de que "é, sem dúvida, à necessidade terapêutica que se deve atribuir a iniciativa de qualquer teoria ontológica da doença" (CANGUILHEM, 1978, p. 19). A convicção de poder restaurar cientificamente o normal é tal, que acaba por anular o patológico. A doença deixa de ser objeto de angústia para o homem são, e torna-se objeto de estudo para o teórico da saúde. (CANGUILHEM, 1978)

Este fragmento da tese de Canguilhem nos aponta a variabilidade da idéia de normalidade - ou de saúde - segundo aquele que a toma como objeto de análise, assim como a relação intrínseca entre a construção de um saber sobre o adoecimento e a necessidade de saná-lo. Pode-se dizer que, dessa forma, foram se delineando através da história conceitos sobre saúde e doença, assim como formas de controlar a 
modificação desse estado de normalidade almejado, de acordo com as transformações da própria sociedade e da concepção sobre o homem dentro dela.

Percorrendo o caminho traçado pela história de tais conceitos percebemos que é a partir do século XVIII que a saúde da população se torna uma questão de interesse do Estado e é através da medicina, como representante de um discurso de saber científico sobre a saúde, que se funda o que hoje compreendemos por saúde pública. (BIRMAN, 2005)

Retornando à saúde mental como aspecto específico do amplo conceito de saúde e que nos interessa particularmente neste momento, podemos dizer que esta só se torna um objeto de interesse para o Estado, e dessa forma um tema de saúde pública, na passagem do século XVIII para o século XIX com o surgimento da psiquiatria como disciplina médica ainda na França.

De início, o que hoje nomeamos de medicina psiquiátrica era denominado 'alienismo', termo cunhado pelo médico francês Philippe Pinel que ficou conhecido como pai da psiquiatria, e sua proposta era oferecer ao alienado um 'tratamento moral', pois se pautava na idéia de que a alienação mental seria "um distúrbio no âmbito das paixões, capaz de produzir desarmonia na mente e na possibilidade objetiva do individuo perceber a realidade”. (AMARANTE, 2007, p. 30)

No Brasil, entretanto, as primeiras medidas de ordem pública relacionadas à saúde mental da população surgiram em meados do século XIX, com os médicos higienistas e suas propostas de reestruturação do espaço urbano. ${ }^{1}$

No entanto, sabemos que o conceito de saúde mental designa o que ao longo da história é mais comumente chamado de loucura e para esta não podemos delimitar uma origem que não remonte até mesmo a eras mitológicas. Sobre a história da loucura e seus diversos significados para a cultura ao longo do tempo podemos

\footnotetext{
${ }^{1}$ Para um estudo mais aprofundado sobre as origens do discurso psiquiátrico ver "A psiquiatria como discurso da moralidade", Joel Birman (1978) e "História da psiquiatria no Brasil" de Jurandir Freire Costa (5 ed., 2007).
} 
contar com uma vasta literatura, dentre elas a célebre obra de Michel Foucault "História da Loucura na Idade Clássica” de 1961.

Buscaremos, todavia, refletir sobre a importância do conceito de saúde mental no que tange à necessidade terapêutica, como aponta Canguilhem, e a trajetória construída cultural e socialmente de tal concepção de saúde que justifica a criação de serviços com a proposta de tratar o sofrimento psíquico, serviços que se colocam como cenário primordial para este estudo uma vez que nos propomos a investigar o acesso a eles por uma parcela específica da população.

Com o advento da medicina psiquiátrica no início do século XIX e a construção de uma nosográfica das patologias mentais, ao teórico e ao profissional da saúde foi atribuída a função de julgar o que foge à normalidade e, neste contexto, quem está doente. Da mesma forma, surgem também propostas de tratamento para tais enfermidades e assim se caracteriza, em importante papel, o trabalhador de saúde mental, papel que de início era centralizado na figura do médico. Segundo Singer, "quando alguém é afetado por sintomas que não podem ser confirmados pelo médico, é duvidoso que seja considerado 'socialmente' doente” (1978, p. 53), idéia que enfatiza a importância daquele que nomeia e afirma a doença.

Ainda sobre o valor do julgamento do profissional, como representante do discurso científico, Singer faz referência a Goffman (1961) que argumenta que "a interpretação psiquiátrica de uma pessoa só se torna significativa na medida em que essa interpretação altera o seu destino social" (SINGER, 1978, p. 53), pois mais do que os sintomas apresentados, é o tratamento aplicado que vai sustentar o diagnóstico social.

Dessa forma, o conceito de saúde mental é constituído não apenas pela definição cientifica do normal ou patológico, mas também pelos valores atribuídos social e culturalmente ao que vem a ser saúde e doença. "Em última análise, a concepção que a sociedade se faz da loucura varia conforme a preferência manifestada por diversos tipos de sanção contra os que apresentam conduta que transgride normas socialmente aceitas" (SINGER, 1978, p. 54). 
Imersos em tal contexto encontram-se então os serviços públicos de saúde, cuja origem nos remete à polícia médica, "com função de impor normas coletivas de conduta visando à saúde pública” (SINGER, 1978, p. 36).

O termo polícia médica diz respeito a um programa iniciado na Alemanha no final do século XVIII que visava registrar dados e contabilizar morbidades, fiscalizar através do Estado os programas de ensino, controlar a atividade dos profissionais da saúde junto à população "e, finalmente, a criação de um corpo de funcionários médicos competentes, nomeados pelo governo, para interferir diretamente com o seu conhecimento e sua autoridade sobre uma determinada região”. (MIRANDA, 1998, p. 7)

Tais medidas iniciaram e constituíram uma medicina urbana na Europa (primeiramente na França) do século XVIII com a preocupação de diminuir as epidemias e endemias que dizimavam a população, muitas vezes causadas pela contaminação da água e do ar pela má organização do espaço urbano.

No Brasil, o conceito de polícia médica é utilizado no século XIX pela sociedade de medicina (formada em 1829) em vários de seus documentos com a finalidade de controlar e fiscalizar a vida social no Brasil, uma vez que encontravam dificuldade para tomar o poder sobre as decisões políticas, centralizadas nas mãos de vereadores leigos em medicina. (MIRANDA, 1998)

Em 1845 é fundado por médicos higienistas o Conselho de Salubridade Pública no Recife e sua meta era "intervir diretamente na desordem urbana, responsável pela ação negativa sobre a saúde física e moral da população". (MIRANDA, 1998, p. 14)

Birman (2005) relata da seguinte forma a tomada do poder médico sobre as questões de saúde da sociedade no início do século XIX no Brasil:

A constituição da medicina científica na aurora do século XIX delineou a problemática da saúde nos registros individual e social. O saber médico configura-se, assim, como clínica e como prática médica, discurso sobre o corpo singular e discurso sanitário sobre o espaço social. Com a emergência da sociedade industrial, a saúde das individualidades passa 
a incluir necessariamente as condições coletivas de salubridade, não sendo mais possivel conceber a existência da saúde dos sujeitos na exterioridade das condições sanitárias do espaço social. (p. 11)

Nesse contexto, a definição do normal e do patológico como citávamos anteriormente, deixa de ser pautada por uma significação pessoal e passa a ser determinada por uma ordem social respaldada pelo discurso médico que ganha forças no crescente movimento higienista.

Enquanto disciplina inscrita na estrutura social, a psiquiatria foi destinatária, portanto, de demandas que visavam a atender e preservar a ordem pública. Mediante esta demanda, inevitavelmente via-se convocada a dar respostas a questões que transcendiam o âmbito da experiência clínica propriamente dita. (TELLES, 2006, p. 15)

Seguindo as medidas de reorganização da atenção à saúde, foi constituída em 1907 a Agência Internacional de Higiene Pública, com o intuito de criar mecanismos de controle, ações de prevenção e saneamento, atraindo a comunidade por meio de campanhas de educação em saúde pública. (TELLES, 2006)

No entanto, o entendimento sobre saúde mental, definido pela influência do alienismo pineliano, dava seus primeiros passos teóricos em terras brasileiras (surgimento das primeiras teses apresentadas às faculdades de medicina do Rio de Janeiro e da Bahia), e o atendimento ao doente mental carecia de especialidade, fundamentação científica e humanização. (RIBEIRO, 1999)

A fim de exemplificar tal condição, Resende (1992) aponta os critérios de seleção da clientela nos recém inaugurados hospitais psiquiátricos brasileiros no início do século XIX:

"Não só a nosologia psiquiátrica estava ausente das instituições (os alienados eram classificados e dispostos nos diversos setores $e$ enfermarias segundo critérios classificatórios essencialmente leigos: alienados comuns, perigosos, criminosos, condenados, etc.), como também leigos eram os critérios de seleção da clientela, a juizo da autoridade pública em geral, o saber médico não sendo chamado nem mesmo para referendar esses processos". (RESENDE in TUNDIS e COSTA, 1992, p. 40) 
Como retrata o conto de Machado de Assis, "O Alienista", a fronteira entre o normal e o patológico, através da importação indiscriminada de teorias deterministas e positivistas, passa a justificar a segregação daqueles que não se encaixam nos padrões sociais da recém constituída República com pouco ou nenhum respaldo técnico e teórico que o justifique.

Seguindo os princípios das ações de higiene pública citadas acima, até a década de 30, período historicamente conhecido como República Velha, “o pensamento político predominante repercutiu no pensamento psiquiátrico, particularmente na ação da Liga Brasileira de Higiene Mental, que influenciou toda uma corrente de psiquiatras cariocas e brasileiros". (RIBEIRO, 1999).

Jurandir Freire Costa (2007), em um resgate à história da psiquiatria no Brasil aponta que nesse momento os psiquiatras, vulneráveis por se apoiarem em uma disciplina ainda fragilmente consolidada, têm a tendência a confundir os problemas psiquiátricos com problemas culturais em geral. Os fenômenos psíquicos eram explicados maciçamente por causas biológicas, sob influencia da psiquiatria alemã, e com tais teorias pretendiam "determinar o modo concreto de organização e funcionamento de todas as instituições sociais, desde a família até o Estado". (COSTA, 2007, p. 42)

O biologismo da Liga Brasileira de Higiene Mental, com suas raízes na eugenia $^{3}$ e concordantes com os preconceitos da época (o racismo, a xenofobia, o moralismo), legitimava o tratamento de segregação e isolamento do doente mental assim como a vigilância e controle da sociedade.

Nesse momento a infância ganha destaque nas ações voltadas à educação, tendo em vista o modelo de higiene mental. A saúde, assim como a educação, direciona seus esforços às crianças considerando-as objeto de especial atenção e

\footnotetext{
${ }^{2}$ O Alienista, publicado entre outubro de 1881 e março de 1882, faz parte do volume de contos Papéis Avulsos de Machado de Assis.

3 "Eugenia é um termo inventado pelo fisiologista inglês Galton para designar o estudo dos fatores socialmente controláveis que podem elevar ou rebaixar as qualidades raciais das gerações futuras, tanto física quanto mentalmente". (COSTA, 2007, p. 49)
} 
preocupação por se tratarem de seres em formação, situação propícia para ações de ordem preventiva. Como aponta Telles (2006):

"A infância é alçada, nas ações de higiene mental, como o ponto de partida sobre o qual se deveria atuar para a prevenção da insanidade $e$ da delinqüência. Este período da vida favoreceria intervenções no destino de um ser ainda em formação, tornando-se, portanto, objeto merecedor de especial atenção e preocupação. Esta concepção extrapola o âmbito da saúde, colaborando para práticas que terão nas instituições escolares um fértil espaço de aplicação". (TELLES, 2006, p. 90)

Assim sendo, "os professores de todos os graus deveriam possuir conhecimentos de Higiene Mental, não só para analisar, compreender e fortalecer a própria personalidade, como também para orientar, através de uma educação progressiva, a formação espiritual e moral de seus alunos” (PACHECO E SILVA 1952, p. 14).

O alvo das ações, no discurso dos higienistas, não era restrito ao âmbito da saúde ou da educação, mas se dirigia ao funcionamento da sociedade em geral, propondo intervenções sobre os costumes e a moral.

O movimento da Higiene Mental e sua preocupação e investimento na infância é considerado um dos propulsores da psiquiatria infantil, pois a partir do ideal deste movimento as crianças começaram a se tornar objeto de ações profiláticas e de tratamento no campo da saúde mental. Nessa época também foram criados os orfanatos, as classes de educação especial e outras instituições de liberdade assistida para crianças e jovens com 'desvio de conduta'. (TELLES, 2006)

Apesar do advento dessas novas instituições, a família e a escola são os principais alvos das ações higienistas, pois eram consideradas as responsáveis pela boa estruturação do caráter e por conseqüência do comportamento das crianças para a vida adulta. Com a atenção voltada para o espaço social, a psiquiatria passa a desenvolver através dos ideais higienistas uma prática profilática sobre a infância e, apoiados no saber médico, passam a transformar as feições da família de elite do Brasil, regendo a organização das relações e da educação. 
Pode-se dizer que o movimento higienista, corporificado no Brasil a partir de 1923 pela Liga Brasileira de Higiene Mental, teve como principal alvo de preocupação até 1925 o aperfeiçoamento da assistência então prestada aos doentes. No entanto, a partir de 1926 sob a influência da noção de eugenia, a Liga passa a se preocupar mais ativamente com a idéia de prevenção e situa a noção de saúde mental como pedra fundamental para qualquer ação no setor da saúde. "A Higiene Mental, que era inicialmente uma aplicação dos conhecimentos psiquiátricos, aparece como a teoria geral que contem e orienta a prática psiquiátrica” (GUAGLIARDI, 1992).

Como princípio geral, as instituições de tratamento de saúde mental abordavam outro aspecto do isolamento, de que a inclusão do indivíduo em uma instituição bem-estruturada, seja ele criança, adolescente ou adulto, pudesse contribuir para a reorganização da própria pessoa. Não por acaso, as instituições eram chamadas: "reformatório de adolescentes", "casa de correção", "penitenciária", “escola normal", nomes que carregam em si o ideal de corrigir aqueles que não estivessem seguindo a conduta estabelecida pelas normas sociais. (LANCETTI e AMARANTE, 2006, p. 620)

"É nessa linha de propostas que o hospital psiquiátrico foi constituído, com o objetivo de operar o que Pinel denominou de tratamento moral, que consiste em uma série de regras, princípios, rotinas, etc., que são adotados nas instituições e que têm como objetivo reorganizar o mundo interno dos sujeitos institucionalizados" (LANCETTI e AMARANTE, 2006).

No entanto, em paralelo às ações da Liga Brasileira de Higiene Mental (nas décadas de 20-30) e contrapondo-se aos ideais eugênicos destacam-se alguns psiquiatras - como Odilon Galotti, James Ferraz Alvim e Ulysses Pernambucano que passam a se dedicar a atividades voltadas para o aperfeiçoamento da assistência psiquiátrica e para a humanização do atendimento, rompendo os limites do hospital psiquiátrico, criando ambulatório em serviços público e escolas especiais para deficientes mentais. (RIBEIRO, 1999) 
Dos psiquiatras citados acima, destacamos ${ }^{4}$ Ulysses Pernambucano e sua concepção de instâncias para o tratamento no Serviço de Higiene Mental. Pernambucano, segundo Cerqueira (1989), propõe em suas obras a existência de um serviço de higiene mental, um ambulatório, um serviço aberto, um hospital psiquiátrico, um manicômio judiciário e uma colônia de alienados como parte de uma estrutura peculiar onde uma instância se apóia na outra, formando um fluxograma que permita a complementaridade entre elas. (RIBEIRO, 1999)

Através da descrição feita por Cerqueira, podemos vislumbrar no projeto de Pernambucano para o funcionamento da assistência em saúde mental muitas semelhanças com as propostas disseminadas pela reforma psiquiátrica que só terá início na década de 40 com o final da Segunda Guerra.

Ulysses Pernambucano, portanto, merece destaque na história da psiquiatria brasileira pelo pioneirismo na constituição de serviços de assistência à saúde mental que ultrapassavam os muros do hospital psiquiátrico, pensando na prevenção de problemas de saúde mental, na composição de equipes multidisciplinares para o trabalho, na criação de um fluxo entre diferentes instâncias de tratamento e na constituição de um prontuário sistemático para cada paciente. (RIBEIRO, 1999)

A partir dos anos 30, o conceito de saúde mental no Brasil começa a contar também com a influência da Psicanálise, que começa a se impor como método de tratamento em oposição ${ }^{5}$ conceitual à Psiquiatria organicista alemã utilizada como maior fonte de referencia e embasamento às idéias higienistas.

Antes de chegar ao Brasil, o desenvolvimento dos conceitos psicanalíticos (no início do século XX) dispara uma subversão na classificação da clínica psiquiátrica. Tais conceitos foram incorporados por outras disciplinas, inclusive pela psiquiatria, que recebeu o nome de "psiquiatria psicodinâmica", e a extensão de seus

\footnotetext{
${ }^{4}$ Considerando nosso especial interesse pela estruturação dos serviços de assistência em saúde mental

5 Embora alguns médicos higienistas tenham se apropriado de conceitos da psicanálise, principalmente a teoria freudiana do desenvolvimento psicossexual infantil, em prol do movimento higienista a fim de justificar medidas profiláticas a futuros desvios de conduta ou mesmo a culpabilização do ambiente familiar por comportamentos indesejáveis por parte das acrianças e dos adolescentes. (GUAGLIARDI, 1990)
} 
fundamentos proporcionou certa dissolução das classificações clínicas propostas por Freud, fazendo surgir novas categorias inclusive dentro da própria psicanálise, que se dividiu em diferentes correntes desde então. (TELLES, 2006)

A preocupação em observar e classificar os fenômenos também constituiu o trabalho de Freud e a construção do conhecimento psicanalítico. No entanto, a diferença entre estes dois campos de conhecimento se estabelece principalmente na concepção das causas subjacentes a tais manifestações sintomáticas. A psicanálise se preocupou desde o início com questões que estavam para além do funcionamento do corpo e pressupôs motivações inconscientes que determinavam os comportamentos do homem. (TELLES, 2006)

Concomitante ao surgimento da Psicanálise como teoria que se opunha aos conceitos até então vigentes, eclodia a II Guerra Mundial e o governo brasileiro opta por vincular-se aos Estados Unidos, transformando a ideologia que havia norteado a intelectualidade brasileira anteriormente de influência européia.

A II Guerra Mundial também traz importantes reflexões a respeito dos maustratos, da violência e da violação dos direitos humanos que ocorriam nos hospitais:

"Após a Segunda Guerra, a sociedade dirigiu seus olhares para o hospício e descobriu que as condições de vida oferecidas aos pacientes psiquiátricos ali internados em nada se diferenciavam daquelas dos campos de concentração: o que se podia constatar era a absoluta ausência de dignidade humana! Assim nasceram as primeiras experiências de 'reformas psiquiátricas'”. (AMARANTE, 2007, p. 40)

As primeiras propostas de reforma surgiram no Reino Unido, no sul da França e na América do Norte, todas voltadas à descentralização do hospital, à inclusão da comunidade e da vida social e à escuta do paciente como alguém capaz de participar de seu próprio tratamento. (LANCETTI e AMARANTE, 2006)

Não podemos nos esquecer também das mudanças disparadas pelo advento dos psicofármacos (antimaníacos, antipsicóticos e antidepressivos) no início da década de 50. A partir de então o tratamento e a compreensão da doença mental se transformaram exponencialmente causando um distanciamento gradativo entre a 
clínica psiquiátrica e a clínica psicanalítica, principalmente pelo movimento de volta da psiquiatria em direção ao campo da medicina, passando a configurar de um lado uma clínica da medicação e de outro uma clínica do sentido. (TELLES, 2006)

Quanto às reformas, na Itália, a partir de 1971, desenvolveu-se a experiência mais original e radical de rompimento ao paradigma psiquiátrico, não apenas de melhoria e transformação. Neste caso, o personagem de maior destaque foi Franco Basaglia, que propôs o fechamento do Hospital Psiquiátrico e sua substituição por serviços territoriais. Para Basaglia, o tratamento só cuidaria efetivamente do sujeito se o considerasse como alguém que pertence a uma comunidade e que, portanto, não deve ser excluído dela.

$\mathrm{Na}$ proposta de Basaglia, a doença é colocada entre parêntesis, e não o sujeito, só assim é possível lidar com aqueles que experimentam o sofrimento sem reduzi-los à doença. Esse novo pensamento também pressupõe uma mudança na relação do paciente com o profissional de saúde mental, tendo em vista que este se depara com uma pessoa, com nome, sobrenome, familiares, desejos, etc., e não com um deprimido ou um esquizofrênico.

Esta é considerada a grande reforma psiquiátrica e na Itália desencadeou um processo que resultou na formulação de uma lei nomeada Lei da Reforma Psiquiátrica Italiana ou Lei Basaglia, em 1978.

No Brasil, com a Constituição de 1988 e a construção do Sistema Único de Saúde, "os hospitais psiquiátricos começaram a ser criticados do ponto de vista ideológico, político, sanitário e fundamentalmente prático" (LANCETTI E AMARANTE, 2006).

Através do princípio da nova constituição em que a saúde é tomada como um direito do cidadão e um dever do Estado começaram a ser efetivadas muitas mudanças no campo da saúde mental, sendo a experiência de Santos a mais conhecida, principalmente pela repercussão no âmbito social. Essa experiência marcou a construção de um sistema de saúde mental pela desconstrução do hospital psiquiátrico e foi promovida pela 'Intervenção', em maio de 1989, no único hospital 
psiquiátrico da cidade, a Casa de Saúde Anchieta. Depois de denúncias de maustratos e de mortes ocorridas no hospício, uma equipe liderada pelo psiquiatra Roberto Tykanori começou a gerenciar essa instituição e uma legião de profisssionais de saúde adentrou o hospital apara cuidar dos pacientes. Quando a equipe técnica e seus pacientes estavam suficientemente integrados e fortalecidos, saía do hospital para criar os NAPS (Núcleos de Atenção Psicossocial), equipamento semelhante ao que recebeu o nome de CAPS (Centro de Atenção Psicossocial) pelo Ministério da Saúde.

É importante ressaltar que os movimentos de reforma ao modelo de assistência em saúde mental tiveram pouca abrangência no que tange à saúde mental infanto-juvenil. Esta permaneceu silenciosa durante muitos anos, ainda sob a égide do pensamento higienista que se pautava no controle das famílias através das instituições de ensino ou mesmo na vida social de forma mais abrangente por meio de discursos moralizantes.

Quanto à definição atual para o conceito de saúde mental, recentemente as publicações neste campo aproximam o conceito aqui discutido de valores como bemestar subjetivo, autonomia, competência e reconhecimento da habilidade para realizar-se intelectual e emocionalmente, seguindo a definição da OMS que caracteriza a saúde como completo bem-estar.

Tal definição não afirmaria um ideal posto ao homem com relação à saúde com tendência a aumentar a quantidade de fenômenos que passam a ser considerados patológicos? Seria possível mensurar a existência desse bem-estar no âmbito do psíquico ou existencial? 


\section{ADOLESCÊNCIA E SAÚDE MENTAL}

\section{Percorrendo o(s) Conceito(s) de Adolescência}

Apesar da noção de adolescência ter surgido apenas no final do século XIX, início do século $\mathrm{XX}$, alguns autores apontam que podemos captar vestígios do adolescente moderno na história em diferentes momentos, como através de textos políticos, o que nos permitiria investigar o lugar do adolescente na nossa sociedade moderna. Serge Lesourd, psicanalista francês, sugere que sobre a história da adolescência só encontramos vestígios, pois, citando Mircéa Eliade:

Falar da adolescência e dos ritos de passagem para a idade adulta que a caracterizam nas sociedades ditas primitivas é falar da própria estrutura da sociedade. Falar do adolescente seria pois desvelar os modelos conscientes e inconscientes de organização das relações humanas e particularmente da troca entre os sexos e da transmissão do poder. (LESOURD, 2004, P. 15)

Como invenção da modernidade, a adolescência nomeia "uma etapa da vida durante a qual o ser humano deixa de ser criança, abandona o universo psicossocial da infância, iniciando, então, um processo característico de mutação física, ao mesmo tempo em que inaugura os primeiros exercícios que lhe possibilitarão ingressar, de corpo e alma, no mundo adulto" (REIS, 1993).

No entanto, quando falamos do sujeito adolescente, principalmente no contexto da saúde, nos deparamos com outras definições que entram em conflito entre si, pois partem de paradigmas filosóficos diferentes.

No paradigma biomédico, "a adolescência é considerada uma etapa de transição entre a infância e a idade adulta, tendo como base as transformações puberais, de caráter biológico, que, por sua vez, desencadeiam mudanças 
psicológicas e sociais, até atingir a maturidade (PERES, 1995). Tal estágio é localizado, neste paradigma, na faixa etária que vai dos 10 aos 20 anos e é compreendido de maneira a-histórica, ou seja, sem considerar aspectos históricos, sociais e culturais que poderiam incidir sobre as experiências dos sujeitos que vivenciam tal fenômeno. Existe uma forte tendência na área da saúde em adotar tal paradigma como norteador de teorias e práticas.

No referencial teórico das Ciências Sociais, que dá preferência ao uso da nomenclatura juventude ao invés de adolescência, tal fenômeno é visto como categoria sócio-cultural e de origem histórica, se opondo, dessa forma, ao ponto de vista biomédico. Tal paradigma situa a adolescência como invenção social gerada no bojo da Revolução Industrial e que apresenta variações culturais enquanto momento de passagem da infância à vida adulta. Neste paradigma, a faixa etária considerada é de 15 a 25 anos. (PERES, 1995)

Fumika Peres (1995), em sua tese de doutorado, aponta ainda a necessidade de considerarmos os aspectos singulares, usando para isso o termo "adolescências", em detrimento de uma visão universal, naturalizada e generalizadora que estaria presente no discurso biomédico. Enfatiza ainda que o conceito de adolescência direciona o olhar ao adolescente, o que retoma a importância de questionarmos a partir de que ângulo compreendemos o sujeito, principalmente no que tange às ações da área da saúde pública.

Para a psicanálise, a adolescência se configura como uma operação psíquica, caracterizada particularmente pelo encontro com as duas funções do adulto: amar e trabalhar - como as definia Freud (LESOURD, 2004).

A psicanálise aborda o sujeito adolescente de outros ângulos, como os processos de luto - seja dos pais, da infância, do corpo infantil; a partir do encontro com o sexo; como passagem que reafirma ou põe a constituição subjetiva à prova e aponta para o momento de sua conclusão... (ROSA, 2002, p. 1)

No texto “As Transformações da Puberdade", Freud situa o ponto de partida dos processos psíquicos do jovem no incremento libidinal e na excitação sexual, visto como fruto de excessos hormonais, diante dos quais sobrevém a reatualização 
de fantasias incestuosas, o que, no confronto com a Lei, exige do jovem o doloroso desligamento dos pais. Tais mudanças e a necessidade de reordenações e composições põem à prova os processos anteriores, com possíveis perturbações patológicas (ROSA, 2002).

Rosa aponta ainda que se deve levar em conta que os processos adolescentes não se referem apenas a um processo de estruturação subjetiva, mas sim a uma reorganização dessa estrutura que possibilita lhe conferir novas significações, principalmente pela via da inserção social (ROSA,2002).

É na cena social que emergem os processos psíquicos característicos da adolescência, como diz Alberti (2002): “identificações, desejo e ideais articulam o sujeito ao grupo social, inserindo-o na cena social através da formação de grupos de amigos, de nova família, inserção no trabalho, em grupos religiosos... Estão aqui os temas básicos da adolescência”.

\section{O Discurso das Políticas de Atenção à Saúde do Adolescente}

Considerando a multiplicidade dos discursos que propõem uma definição do sujeito adolescente, no campo das políticas públicas, levando em conta especificamente os documentos oficiais de atenção à saúde do adolescente, encontramos também caracterizações conceituais nas quais se baseiam e sobre as quais são erigidas propostas de intervenção.

Colocamos em destaque o discurso do Ministério da Saúde, da Organização Mundial de Saúde e da Organização Panamericana de Saúde como órgãos gestores nacionais e internacionais que veiculam tais documentos e conseqüentemente concepções sobre a assistência a esse grupo. 
Tomando como base a análise feita por GROSSMAN e CARDOSO (1997) dos documentos oficiais divulgados por esses três órgãos sobre a atenção à saúde do adolescente, divulgados a partir de 1976 até 1994, destacam-se três critérios como definidores do conceito de adolescência: “o cronológico, ligado às transformações somáticas, o da construção de um padrão típico do adolescente e o da hegemonia do biológico, (...) onde o papel do médico está postulado como o de dizimador de conflitos (...)" (1997, p. 1).

Como critério cronológico, tais documentos caracterizam o período da adolescência como aquele "compreendido entre os 10 e os 19 anos, isto é, a segunda década de vida. (...) A adolescência é também subdividida em duas fases: adolescência inicial - 10 a 14 anos - e a adolescência propriamente dita ou segunda fase -15 a 19 anos. (GROSSMAN e CARDOSO, 1997, pag. 3)

As autoras ressaltam, na análise feita a esses documentos, que o critério utilizado para contemplar a totalidade dos adolescentes tinham por base as mudanças morfológicas e fisiológicas que constituem a puberdade, fenômeno caracterizado pelo processo de desenvolvimento biológico.

Além do critério baseado nos eventos puberais, o estudo também aponta a ênfase dos documentos na definição de adolescência como fase de transição da infância à idade adulta, composta por transformações psicológicas e pela busca de uma identidade madura, movidas por atitudes sociais reivindicatórias, ao que apontam a importância de considerar que "essas não são vivências circunscritas a um período de tempo previamente estabelecido". (GROSSMAN e CARDOSO, 1997, pág. 3)

Quanto à existência de um padrão típico da adolescência, os textos remetem à suposição de que haja um modelo característico do adolescente que serviria de referência para a definição do que vem a ser normal e patológico nesse período da vida, determinado por uma lista de comportamentos esperados e que comporiam então o sujeito adolescente. Quanto a essas definições, GROSSMAN e CARDOSO questionam se "a descrição de tal 'fenômeno sindrômico' nega o fato do homem 
assumir uma forma própria de ser em cada tempo e lugar históricos, restringindo suas características a um mero desenvolvimento cronológico" (1997, p. 4), o que nos parece uma boa indagação.

"As definições de adolescência, presentes nos documentos avaliados, são considerações homogeneizantes, minimizando a diversidade de formas que o adolescente ou grupo de adolescentes possam adotar no cotidiano de suas vidas inseridas na coletividade. As tradições, os costumes, os ritos não são salvaguardados, sendo pelo contrário, nivelados e uniformizados. Os documentos, portanto, traduzem uma concepção pragmática e empiricista da história, alienada da temporalidadelespacialidade humana que, neles, se transforma em um substrato passivel de previsibilidade e controle". (GROSSMAN e CARDOSO, 1997 p. 4)

De acordo com essa perspectiva, o papel do profissional de saúde descrito nos documentos analisados (de 1976 a 1994) é o de dizimador de conflitos,

\begin{abstract}
"um médico que atende adolescentes deverá ser capaz de diagnosticar e tratar doenças físicas, detectar condutas desadaptativas, estar alerta a potenciais falhas no rendimento escolar, fomentar o desenvolvimento de estilos de vida saudáveis, ensinar educação sexual e realizar aconselhamento familiar. Deverá compreender as transformações da adolescência e outorgar um nexo vital entre o adolescente e sua família, o que manterá as relações harmônicas" (MADDALENO, 1988 p. 136 apud GROSSMAN e CARDOSO, 1997 p. 9).
\end{abstract}

Mais recentemente, no ano de 2005, o Ministério da Saúde divulgou um documento intitulado "Marco Legal - Saúde, um Direito de Adolescente", onde a definição de adolescência é marcada pela perspectiva de um processo de desenvolvimento biopsicossocial.

A puberdade é descrita como parâmetro universal, ocorrendo de maneira semelhante em todos os indivíduos, mas a adolescência, considerada para além dos fenômenos puberais, é singular e caracterizada por influências socioculturais que vão se concretizando por meio de reformulações constantes de caráter social, sexual e de gênero, ideológico e vocacional (BRASIL, 2005a, p. 8).

O mesmo documento adota a noção de vulnerabilidade como forma de entender a experiência do jovem frente aos riscos, tais como: "questões de gênero cruzadas com raça/etnia e classe social; condições de vida; condições de saúde; 
acesso ou não à informação; insuficiência de políticas públicas em saúde e educação, etc.” (BRASIL, 2005a, p. 9).

O texto também aborda a importância da consideração da pluralidade de sujeitos e adota o termo "adolescências" como forma de definição que englobe o contexto sociocultural do adolescente, situando-o em um tempo e cultura específicos.

Este novo documento é pautado pelos princípios da universalidade, da igualdade, da preservação da autonomia, da prioridade (enquanto segmento infantojuvenil), do direito à informação, da intersetorialidade e da resolutividade (BRASIL, 2005a).

Ainda em 2005, outro documento de importante repercussão para a política de assistência em saúde mental infanto-juvenil foi elaborado e divulgado pelo Ministério da Saúde. Nomeado como "Caminhos para uma política de saúde mental infanto-juvenil", o documento é composto por diretrizes, portarias, recomendações e textos que remontam o contexto histórico das ações de saúde mental destinadas a essa população.

Logo na apresentação do documento, Humberto Costa, então ministro de estado da saúde, justifica a adesão do Ministério à proposta da construção de uma nova política de saúde mental pela Organização Mundial da Saúde e pela Federação Mundial de Saúde Mental como forma de preencher uma lacuna histórica deixada pela ausência de uma política de saúde mental voltada para esse público, admitindo que tal lacuna tenha tido como conseqüência a ausência de um tratamento adequado de crianças e adolescentes. (BRASIL, 2005b)

Nesse documento, percebe-se uma leitura mais complexa acerca do conceito de saúde mental e de seu enlace com a lógica higienista e normativa, principalmente no contexto infanto-juvenil, como explorado na primeira parte desta introdução.

Sob um novo ponto de vista, o discurso de tal documento admite como um dos maiores desafios para a área da saúde mental a construção de uma política voltada para a população de crianças e adolescentes que considere suas 
peculiaridades e necessidades e que siga os princípios estabelecidos pelo SUS, principalmente aqueles que apontam para a intersetorialidade, construindo uma rede ampliada de atenção em saúde mental.

Idéias como a da implicação de um sujeito responsável por sua demanda, seu sofrimento e seu sintoma despontam como novidades discursivas tendo em vista o público infanto-juvenil, uma vez que estes sempre foram vistos como incapazes de falarem por si mesmos e de comunicarem seu sofrimento de forma compreensível e válida. Dessa forma destaca-se a seguinte proposição:

"Incluir, no centro das montagens institucionais, a criança ou o
adolescente como sujeitos, com suas peculiaridades e responsabilidades
sobre o curso de sua existência, é o único modo de garantir que não se
reproduza na sua assistência o ato de se discursar sobre ela, de saber,
por ela, o que é melhor para ela". (BRASIL, 2005b)

Dentro da proposta de analisar o discurso das políticas de atenção à saúde do adolescente, encontramos neste último documento uma mudança significativa que aponta para a concepção de sujeito de direitos e sujeito de desejo que ultrapassa qualquer limitação etária ou classificatória sem, entretanto, desprezar a singularidade de suas necessidades. 


\section{OS DESAFIOS NA CONSTRUÇÃO DE UM NOVO \\ MODO DE RECEBER OS QUE CHEGAM}

\section{Modalidades de Atenção e suas Perspectivas}

O modelo de atenção à saúde mental de adolescentes na cidade de São Paulo é definido por uma política de atenção à saúde mental da infância e adolescência através da resolução SS-17, de 19 de fevereiro de 2001.

Este documento, elaborado sob a iniciativa da Secretaria Estadual da Saúde através de sua Assessoria de Saúde Mental e que contou com a participação de especialistas em saúde mental da infância e adolescência pretende servir de ponto de partida para orientar o desenvolvimento e a ampliação deste campo assistencial.

As diretrizes estruturantes dessa proposta são as mesmas das preconizadas pelo SUS, de universalidade, integralidade e equidade. $\mathrm{O}$ acesso aos serviços deve ser universal e as ações planejadas e implantadas devem pautar-se na legislação em vigor, em especial no Estatuto da Criança e do Adolescente (ECA) de 1990 e na lei da Reforma Psiquiátrica de 2001.

O modelo de atenção tem como missão "a promoção do desenvolvimento humano e, para tanto, pretende desenvolver ações que visem evitar o surgimento, o desenvolvimento e a persistência de dificuldades na área de saúde mental em crianças e adolescentes" (São Paulo [Estado], 2002, p. 5).

A rede de serviços assistenciais é formada pela atenção básica, cuidados ambulatoriais especializados, centros de cuidados diários, serviços de urgências e emergências, residências terapêuticas e equipamentos de internação, sendo eles enfermarias de curta permanência. 
A Atenção Básica compreende as atividades desenvolvidas por Equipes de Saúde da Família, Unidades Básicas de Saúde e outras unidades não especializadas em Saúde Mental. Tais atividades são descritas da seguinte forma:

- Atividades de promoção de fatores protetores da saúde mental na população geral através de intervenções comunitárias;

- Atividades preventivas em saúde mental visando grupos de risco para desenvolvimento de problemas de saúde mental;

- Atividades de diagnóstico precoce e tratamento de transtornos mentais.

O documento prevê que a necessidade de encaminhamento para serviços especializados depende mais de fatores como capacitação dos profissionais da rede básica, vínculos estabelecidos com estes profissionais, maior facilidade de acesso do que do diagnóstico propriamente dito e que o tratamento pode ser feito em dois tipos de serviços concomitantemente.

No que tange aos Cuidados Ambulatoriais Especializados, o documento propõe que existam equipes especializadas que possam atuar voltadas somente para o trabalho com crianças e adolescentes, independente do local onde esta equipe atue (ambulatório de saúde mental, centros de cuidados diários [CAPS], unidade básica de saúde), pois caracteriza-se fundamentalmente pelas funções:

- Ser referência e suporte para os profissionais que atuam no nível primário de atenção, assim como outros equipamentos de saúde, educação, cultura, etc.;

- Executar avaliação diagnóstica, estabelecer programas terapêuticos para crianças ou adolescentes cujo transtorno é grave e/ou complexo o suficiente para demandar investigação por uma equipe multiprofissional ou por profissional especializado, ou ainda, que tenha suscitado dúvida para o profissional de nível básico de atenção à saúde;

- Acompanhamento terapêutico para os indivíduos com transtornos de maior severidade que não tem indicação de acompanhamento nos equipamentos 
mais sofisticados e de maior intensidade (centros de cuidados diários, internação) ou que estão em processo de transição, com indicação de entrada ou saída destes locais de maior intensidade.

A equipe mínima descrita para essas funções é formada por 01 psiquiatra, 01 psicólogo, 01 assistente social, 01 fonoaudiólogo, 01 terapeuta ocupacional e 01 enfermeiro.

Os Centros de Cuidados Diários são descritos como recursos assistenciais a crianças com transtornos globais do desenvolvimento mental que se iniciam precocemente ou com outros transtornos emocionais graves e sua principal característica é a competência e capacitação adequada dos profissionais que integram tal equipe.

Seus critérios de admissão são voltados para pacientes com distúrbios psíquicos susceptíveis de entravar, de forma importante, o funcionamento social global, e que não têm condições de tratamento em regime ambulatorial menos intensivo, a depender dos critérios da equipe do CCD (centro de cuidados diários). Diz ainda que tal equipamento não deve ser porta de entrada do sistema, a não ser em condições excepcionais.

Os serviços de Urgências e Emergências são orientados a oferecer cuidados especiais a crianças e adolescentes, colocando como prioridade a segurança destes, tanto em relação a si mesmo quanto em relação a terceiros. A necessidade de internação em unidades de maior tempo de permanência deve ser avaliada pela equipe deste serviço seguindo os seguintes critérios

- Risco de suicídio;

- Depressão grave; distúrbio comportamental; psicose com família não continente.

- Fracasso do tratamento ambulatorial intensivo e/ou indicação da equipe de referência. 
- Hetero e/ou auto-agressão resistente a tratamento ambulatorial.

- Quando o ambiente familiar não é seguro para a criança ou adolescente.

As Residências Terapêuticas são dispositivos acionados no caso de crianças com transtornos globais do desenvolvimento severos e outros transtornos mentais graves nos seguintes casos:

- Quando não houver nenhuma estrutura familiar disponível para a criança ou adolescente;

- Quando o afastamento dos pais, muitas vezes temporário, for avaliado como uma medida capaz de gerar efeitos importante no tratamento da criança, ou seja, quando a residência for tomada como um dispositivo clínico no tratamento das crianças e dos adolescentes;

- Quando recomendada por profissional da área técnica.

Os programas de Internação Psiquiátrica de crianças e adolescentes devem ser estruturados para fornecer esclarecimentos diagnósticos, melhorar o comportamento quando possível, ajustar dosagem de medicamentos, otimizar orientação familiar ou em casos de risco de auto ou heteroagressividade.

Os critérios de internação são descritos da seguinte forma:

- Crianças e adolescentes com problemas psiquiátricos graves ou fase aguda da doença. A internação ocorrerá apenas quando houver reconhecimento da falência do ambiente familiar para continência do quadro;

- As internações deverão ser realizadas quando não houver condições médicas de tratamento ambulatorial, sendo o pedido de internação avaliado pelo médico responsável pela enfermaria. Exceções são feitas em casos de recaída por suspeita da não ingestão da medicação ou dúvidas diagnósticas, em casos muito complicados; 
- Os casos de urgência serão internados somente para melhora da fase aguda com controle imediato do quadro;

- Os pacientes deverão ser internados com a presença de um familiar em tempo integral, exceção feita apenas em casos nos quais existir indicação técnica para separação da família ou quando situações sociais concretas não o permitirem. A presença da família é fundamental para que seja preservado o vínculo mãe-filho, importante sob o ponto de vista terapêutico e para a consecução de orientações, práticas educativas ou mesmo terapêuticas no conjunto paciente-família. Assim, a equipe poderá observar como se dá esta relação, além de que tal atitude mostrou-se de grande importância na diminuição do número de internações, bem como no índice de re-internações.

- A internação em enfermarias especializadas em crianças e adolescentes somente poderá ser efetuada se o paciente tiver no máximo 17 anos.

A implantação de uma política de atenção à saúde mental de crianças e adolescentes também pressupõe a disponibilidade de recursos humanos com formação específica nesta área e a isso compreende garantir mecanismos de capacitação e qualificação dos profissionais que atuam no campo da infầncia e da adolescência, assim como criar uma política nacional de formação que inclua treinamento e supervisão dos profissionais da rede básica envolvidos no atendimento ao usuário.

A supervisão permanente visa o auxílio de um profissional de fora, o supervisor, que não estando diretamente envolvido com o trabalho poderia ajudar as equipes que por mais preparadas que estejam esbarram na dificuldade com relação aos conflitos internos provocados pelo trabalho que desenvolvem. Também está prevista na capacitação do profissional a atualização permanente, por intermédio de cursos de reciclagem e encontros regulares com outras equipes de saúde mental, não como meio de compensar as falhas de formação das equipes, mas como estratégia para oferecer à população serviços cada vez melhores, tendo em vista a rapidez das conquistas científicas no campo da saúde mental. 
Esta última proposta, referente à formação para o trabalho em saúde mental infanto-juvenil, nos leva a aprofundar alguns aspectos a respeito dos trabalhadores que atuam no campo da saúde mental e que figuram como sujeitos deste estudo, especificamente na sua relação com os novos usuários.

Antes de partirmos para o exame das questões referentes ao trabalhador de saúde mental, devemos acrescentar a essa análise sobre as modalidades de atenção o documento anteriormente citado que data de 2005 e se intitula "Caminhos para uma política de saúde mental infanto-juvenil”. Tal documento, mais recente do que esse no qual nos baseamos para definir a rede de atenção atual, não caracteriza o formato e a definição das unidades acima descritas, nos fazendo supor a vigência de tais informações. No entanto, nesse novo documento o equipamento até então descrito como Serviço de Cuidados Diários dá lugar ao CAPS como unidade de base da Reforma Psiquiátrica Brasileira e os princípios do funcionamento da rede são então priorizados, como base do funcionamento de qualquer serviço.

Entre os princípios para a assistência dessa população estão: o acolhimento universal, o encaminhamento implicado, a construção permanente de rede, o território e a intersetorialidade na ação do cuidado.

$\mathrm{O}$ acolhimento universal pressupõe que as portas estejam sempre abertas a toda e qualquer demanda dirigida ao serviço de saúde do território; o encaminhamento implicado exige que aquele que encaminha esteja incluído e se responsabilize pelo endereçamento da demanda; a construção permanente de rede implica no trabalho conjunto com os demais serviços e equipamentos do território; o território define o lugar psicossocial do sujeito e, por fim, a intersetorialidade na ação do cuidado indica a ampliação das ações para além do campo clínico, incluindo serviços de qualquer natureza que atravessem a vida do sujeito. 


\section{O Trabalhador da Saúde Mental e Tarefa de Discernir}

Merhy (1997) aponta que "o trabalhador de saúde ocupa um espaço que possibilita um alto grau de autonomia, que lhe dá, inclusive, a possibilidade de privatizar decisões e ações de acordo com critérios extremamente subjetivos e particulares, sem que tenha que prestar conta sobre o que faz, nem sobre o como faz. Desta forma, é sempre grande o risco de perder-se o real objeto da ação, o usuário e suas necessidades". (MÂNGIA et al. 2002).

Com essa afirmação, o autor nos lembra que o trabalho em saúde opera a partir do espaço relacional definido pelo encontro entre o trabalhador e o usuário e que só a partir desse encontro é que se identificam as necessidades de saúde, estabelecendo a trajetória dos usuários no serviço.

Pouco se pensava, nos anos 70, na subjetividade e no corpo dos trabalhadores da saúde. "Essa linha, preocupada com a crítica, produziu intensos questionamentos sobre a clínica, a biologização excessiva das práticas e chamou muito bem a atenção para o processo de construção sócio-histórico das categorias operatórias dominantes". (ONOCKO CAMPOS, 2005).

No final dos anos 90, o tema da subjetividade se destaca através da reforma da clínica e da mudança do modelo assistencial e passa a ser uma questão importante em prol da eficácia do SUS. A partir do tema da subjetividade esboça-se uma preocupação com as instituições de saúde. Surgem novos referenciais teóricos para pensar as relações entre as pessoas e as instituições, como a socioanálise, esquizoanálise e psicoterapia institucional, porém pouco exploradas por não estarem entre as disciplinas clássicas estudadas pelos sanitaristas.

Alguns autores transitaram o caminho entre saúde coletiva e psicanálise na redescoberta do tema do sujeito, e nessa perspectiva teórica encontramos o sujeito movido por questões inconscientes, ou seja, que ele próprio desconhece. Pensar no 
trabalhador e nos desafios de seu trabalho levando em consideração as questões inconscientes que movem as ações do ser humano, ou seja, como um ser "barrado", que nunca será absolutamente dono de si, que não pode tudo e nunca terá a certeza de conhecer apuradamente o rumo de seu desejo (ONOCKO CAMPOS, 2005, pág. 576), mudará nossa forma de abordar os equipamentos de saúde e as relações que ali se desenvolvem.

O vínculo do trabalhador com a instituição e a crença no valor positivo do próprio trabalho constituem funções estruturantes da subjetividade e ajudam a suportar o mal-estar advindo das tarefas coletivas. Os sujeitos necessitam se identificar favoravelmente com a missão do estabelecimento no qual trabalham e quando esse contexto coloca entraves à sua tarefa, valem-se de estratégias defensivas para atenuar o próprio sofrimento psíquico, sendo uma delas o excesso de ideologização.

Podemos pensar que esses "sintomas institucionais" são produzidos pela própria realidade do trabalho, por estarem permanentemente em contato com a dor, a morte e a dificuldade de simbolização que algumas situações nos provocam. Para este entrave, talvez a única saída seja o reconhecimento da dimensão inconsciente nas relações de trabalho para que este seja possível.

Além disso, é importante definir quais os meios técnicos que um trabalhador possui, não só para a eficácia de sua prática, mas também pela interferência no grau de resistência que o sujeito em questão conta para enfrentar no dia-a-dia a dor e o sofrimento.

Muito se tem falado sobre a questão do cuidado nas instituições de saúde, refletindo uma preocupação com as questões de ordem intersubjetiva em detrimento às questões técnicas envolvidas no encontro assistencial, no entanto, é inegável que o que diferencia os trabalhadores de saúde do restante da população é sempre "um dado saber", constituindo um grave erro descartarmos as competências dos saberes técnicos e da clínica na tentativa de fazermos crítica à leitura tecnicista da saúde. 
O trabalhador de saúde que não conte com razoável formação técnica será submetido a mais um fator de sofrimento, a angústia de 'nada saber'. "Quando a insegurança técnica é grande, toda demanda é amplificada, não é possível discernir em relação a riscos e urgências". (ONOCKO CAMPOS, 2005, pág. 579). Sendo assim, o conhecimento técnico teria duas funções produtoras de eficácia, uma quanto à produção de saúde do usuário e outra na produção de saúde do próprio trabalhador, pois estar em contato significa expor-se a afetos e, portanto, ser afetado.

Portanto, pensar neste encontro, entre trabalhador e usuário, considerando o usuário como aquele que demanda e o trabalhador como aquele que recebe tal demanda e oferece algo em troca, não podemos deixar de considerar também as dificuldades e os desafios que este encontra no processo de seu trabalho.

O conhecimento técnico-científico e o reconhecimento de que existem questões inconscientes que fogem ao controle do homem e que agem nas relações inevitavelmente são as ferramentas disponíveis para que o trabalho seja possível e para que o profissional possa oferecer, além de seu 'saber', o acolhimento ao sofrimento psíquico daquele que procura ajuda nos serviços de saúde mental.

\section{Necessidade e Demanda nas Portas dos Serviços}

Antes de abordarmos com maior atenção o tema do acolhimento enquanto nova e importante tarefa do trabalhador de saúde mental, tendo em vista que hoje se constitui como estratégia difundida entre os serviços de saúde a fim de garantir o acesso universal da população (como um dos princípios do SUS), nos deparamos com um primeiro desafio: refletir sobre os conceitos de necessidade e demanda em saúde mental 
No entanto, para que tenhamos a possibilidade de refletir sobre as necessidades de saúde, esbarramos mais uma vez no conceito de saúde anteriormente problematizado. Como apresentado no primeiro capítulo desta introdução, os conceitos de saúde e doença não devem ser tomados como conceitos simples e consensuais nem mesmo devem ser abordados sem uma discussão complexa de suas diferentes representações culturais e sociais considerando ainda que estas mudem de sentido segundo aquele que o utiliza.

Dessa forma, também o conceito de "necessidade de saúde" será considerado neste trabalho como um conceito complexo e ambíguo, fortemente determinado por fatores de ordem política, social e mesmo pessoal.

De modo geral, podemos tomar como ponto de partida que o homem possui necessidades fundamentais que estão intrinsecamente ligadas à manutenção da vida $\mathrm{e}$ neste ponto podemos considerar desde a alimentação, moradia, vestimenta, saúde e educação, como também algumas necessidades sociais como a satisfação no trabalho, a liberdade, a paz, a eliminação das guerras, o respeito entre os seres humanos e o bem-estar. (SAN MARTÍN e PASTOR, 1989)

"Resumiendo, las necesidades realmente fundamentales son las biológicas y aquellas otras sociales que históricamente se han transformado en necesidades indispensables a la vida del hombre. Pero esta definición tiene contenidos variables según las épocas históricas, según las clases sociales, según las culturas, según el sexo y la edad, según el nivel educacional, etc." (SAN MARTÍN e PASTOR, 1989)

Partindo dessa concepção de necessidade fundamental, encontramos ainda a existência de outras necessidades que se apresentam como demandas aos serviços de saúde e que precisam ser analisadas com cuidado para que não incorramos no erro de dividi-las em verdadeiras ou falsas.

Pode-se dizer, com a intenção de organizar as idéias, que uma necessidade pode ou não se constituir como demanda na medida em que se configura como um pedido com implicação daquele que o faz. No entanto, o entendimento do que vem a 
ser a demanda por serviços de saúde também encontra divergências em sua definição.

Para Campos (1969), “a demanda, no sentido convencional do termo não pode ser aceita como indicador de necessidades, desde que ela é afetada por inúmeros fatores, entre os quais o desejo de lucro por parte do empresário privado, a percepção deficiente por parte do usuário e as decisões nem sempre racionais por parte dos demais ofertantes de serviços de saúde". Em função dessa concepção de demanda, o autor propõe que sejam realizados estudos científicos tendo em vista investigar as reais necessidades de saúde da população através de inquéritos de morbidade e estudos epidemiológicos.

No entanto, tal definição parte do pressuposto de demanda do ponto de vista econômico, definida como "a quantidade do bem ou serviço que as pessoas desejam consumir em um determinado período de tempo, dadas as suas restrições orçamentárias" (IUNES, 1995).

Ainda assim, Iunes (1995) aponta que partindo dessa definição dois aspectos devem ser abordados, a noção de desejo enquanto estrutura de preferências, dirigindo nossas escolhas para o que nos traga maior satisfação ou felicidade, e a presença de uma restrição orçamentária, segundo a qual distribuímos nossos recursos limitados entre produtos, serviços, lazer, etc. para conseguirmos a maior utilidade.

A presença de uma escolha frente à necessidade parece definir e constituir a demanda, escolha essa que é atravessada por uma série de determinantes que colocam em xeque sua espontaneidade.

No caso da saúde mental, como aponta Bezerra Junior (2007), de um lado existe uma demanda naturalizada, ou seja, uma demanda identificada como fato natural que se expressa através de sintomas com origens em distúrbios somáticos ou psicológicos, provenientes de conflitos pessoais; de outro lado a demanda como produto social que explicaria o adoecimento como expressão de maneira indireta e distorcida da doença da própria sociedade. 
Diante dessa polêmica divisão, o autor aponta que "talvez seja mais frutífero considerar a possibilidade de, contornando tanto a confusão quanto a escolha definitiva de um destes pontos de vista, abrir um espaço para questões que procurem detectar no idiossincrático a marca do social” (BEZERRA JUNIOR, 2007, p. 147).

Isso porque, ainda segundo o mesmo autor, podemos tomar dois pontos de vista diante da procura de tratamento em saúde mental que tornam a questão ainda mais delicada: o ponto de vista do espectador e o ponto de vista do agente.

Nessa perspectiva, o espectador é aquele que se encontra diante da procura e que se interessa em observar suas determinações históricas, sociais e ideológicas que escapariam à consciência do paciente, mas que estariam determinando sua conduta. Podemos pensar que este espectador pode ser o pesquisador que se dispõe a refletir sobre as questões de saúde mental, mas comumente é aquele que está no serviço para receber e tratar (se for o caso) aquele que chega em busca de tratamento, o trabalhador de saúde mental.

Em outra perspectiva se encontra o agente, aquele que sente a necessidade de ajuda. Este, segundo Bezerra Junior (2007), “não percebe a sua busca de tratamento como resultado de um processo de medicalização de sua existência, ou de despolitização pela psiquiatria dos conflitos sociais em que está imerso. É o sofrimento que lhe move, é a superação desta experiência dolorosa que ele almeja". (p. 146)

Quando a proposta é refletir sobre a porta de entrada nos serviços de saúde mental, nos vemos diante deste intrincado cenário em que figuram conceitos e personagens complexos e com propósitos diversos. Ao priorizarmos nessa investigação a população adolescente, se de um lado restringimos nosso objeto de estudo, de outro ampliamos largamente nossas perguntas.

Tendo em vista os argumentos exposto até esse momento, o que seria uma verdadeira necessidade de saúde mental para os adolescentes? Quais seriam as demandas levadas aos serviços de saúde e como elas são recebidas pelos trabalhadores de saúde mental? 
Em artigo publicado em 2006 sobre adolescentes e suas relações com os serviços de saúde, a titulo de introdução as autoras apontam:

"Há alguns anos, a adolescência era o periodo de menor risco de adoecimento e morte. No entanto, nas duas últimas décadas, observou-se um aumento da morbimortalidade nesse grupo populacional. De um lado, pesquisas científicas têm revelado que várias alterações orgânicas, advindas de hábitos de vida pouco saudáveis, já estão instaladas nesse momento da vida, constituindo-se em fatores de risco para doenças, principalmente na vida adulta. De outro lado, comportamentos de risco são cada vez mais comuns, como conseqüência, principalmente, de tensões econômicas e sociais". (CLARO et al, 2006, p. 1565)

As autoras ainda apontam que com base nesse aumento da morbimortalidade adolescente, que se observa em várias partes do mundo, os sistemas de saúde vêm propondo formas de investigar e de criar programas que sejam capazes de atender às necessidades dos adolescentes. No entanto, concluem que "a auto-avaliação do estado de saúde tem sido usada como indicador importante sobre o comportamento da população com relação à busca por serviços de saúde devido à dificuldade de mensurar-se a necessidade de saúde" (CLARO et al, 2006, p. 1570), considerando este como conceito impreciso e agrupando-o em duas categorias, segundo a literatura, sendo elas o estado de saúde percebido individualmente e o avaliado pelo profissional.

As necessidades percebidas, segundo San Martín e Pastor (1989), são aquelas que a população identifica através de sintomas ou através da demanda de serviços de saúde e se distinguem das demandas fundamentais mais pela forma de satisfação do que por sua natureza. Enquanto as demandas fundamentais se satisfazem por meios materiais (como o alimento, por exemplo), as demandas percebidas se satisfazem pelo estabelecimento de relações psicossociais.

Em relação aos adolescentes, portanto, temos indícios para pensar que é através da demanda aos serviços de saúde (no caso deste estudo, de saúde mental) que eles expressam suas necessidades. A identificação destas necessidades, assim como o encaminhamento possível para sua satisfação, dependeria em grande parte da leitura dos "espectadores" (utilizando ainda o termo empregado por Bezerra Junior) 
que no caso específico dos serviços de saúde mental se configuram como os trabalhadores que os acolhem.

\section{A Prática do Acolhimento e a Questão do Acesso}

O acesso dos usuários e a forma de recebê-los são aspectos fundamentais do contexto e das práticas diárias dos serviços de saúde mental. Os serviços são organizados, no geral, segundo a oferta limitada e pré-estabelecida de procedimentos.

A estratégia de acolhimento relaciona-se com a demanda, e está configurada como uma forma singular de receber, compreender e relacionar-se com a clientela. $\mathrm{O}$ acolhimento vem a ser um modo de atender mais prontamente aqueles que procuram o serviço, garantindo o acesso e propiciando maior proximidade às necessidades das pessoas.

A idéia de recepção humanizada e a estratégia de acolhimento nasceram no contexto da desinstitucionalização e da busca de serviços substitutivos ao modelo asilar no bojo da reforma psiquiátrica e da constituição do SUS.

Autores que atualmente refletem sobre as modificações no sistema de saúde, com o advento do SUS, apontam a prioridade de se planejar novos mecanismos que levem em conta as necessidades que chegam através de uma demanda, superando a burocratização e com isso provocando alterações nos modos de fazer e pensar o conceito de saúde.

A estratégia de acolhimento passa por três tipos de processos, definidos a partir de eixos temáticos. Os processos são de subjetivação, de responsabilização e de organização dos serviços. O processo de subjetivação está associado ao “estabelecimento de relações que permitam ao usuário a apropriação, a significação e 
a reconstrução de suas histórias de vida e possibilitem a singularização das soluções para a promoção da saúde" (MÂNGIA et al., 2002, pág. 17).

O processo de responsabilização está relacionado à divisão de poder com a qual profissional e usuário tomam para si os problemas e a tarefa de solucioná-los, favorecendo a autonomia; o processo de organização dos serviços aponta para o rompimento com a verticalidade das estruturas e com a centralização do poder de mando e para o planejamento voltado às necessidades locais.

A relação permanente com a demanda é uma proposta que implica na preocupação com a qualidade do cuidado e na disponibilidade das equipes de se implicarem e compartilharem com aquilo que aflige seus pacientes, possibilitando uma escuta diferenciada no momento em que chegam ao serviço, partindo do pressuposto de que o momento em que o sujeito ou seus familiares decidem recorrer a um serviço de saúde mental é o momento em que se convencem de que seus próprios recursos não são mais suficientes.

A diretriz do acolhimento deve fazer parte da proposta dos serviços e por si só desencadeia nas equipes reflexões sobre o processo saúde-doença e sobre o tratamento, cujo foco não deve se restringir aos sintomas, mas a todas as implicações na vida do sujeito. É também o que possibilita e autoriza a presença do usuário tão logo sinta que algo não está bem, permitindo à equipe intervenções que evitam o agravamento e a necessidade de medidas como a hospitalização.

O procedimento mais utilizado para receber os novos usuários nos serviços é a prática da triagem. “A expressão triagem alude mais ao interesse da instituição de filtrar quem pode e quem não pode ser atendido, baseada na lógica da oferta, previamente estabelecida pelo serviço, e não da necessidade da pessoa" (CARVALHO e CAMPOS, 2000; LEVCOVITZ et al., 2000).

\footnotetext{
"A prática da triagem, geralmente composta por agendamento prévio e realização de uma entrevista, responde a uma preocupação de dividir e classificar sintomas e indicar rapidamente um tratamento, constituindo uma relação vertical, onde o profissional é quem decide o tipo de intervenção com base em critérios, muitas vezes aleatórios e extremamente subjetivos,
} 
tais como: o diagnóstico psiquiátrico e sua condição sintomatológica no momento da entrevista, a necessidade ou não do uso de medicação, o grau de escolaridade da pessoa, a suposta situação social, a capacidade de verbalização e compreensão, dentre tantas outras". (OLIVEIRA, 2000 apud MÂNGIA et al., 2002, p. 18).

Acolher, diferente de triar, significa receber bem com disponibilidade para escutar e valorizar as particularidades daquele que procura o serviço, promovendo condições para que ele expresse seu sofrimento e com isso possa ser definido um projeto terapêutico.

A prática de acolhimento não pressupõe que os serviços devam dispor de todos os recursos necessários para cada caso, mas devem desenvolver a possibilidade de agenciar recursos e soluções mais adequados às situações. Assim sendo, a prática do acolhimento propicia um efeito em cadeia, ou em rede, onde as demais instituições, sejam elas educacionais, culturais ou sociais, estejam conectadas em busca de respostas que articulem soluções para o usuário que busca atendimento. Nesse sentido, a noção de território é de extrema importância, pois é na própria comunidade que o serviço vai se ancorar para dar suporte naquilo que a instituição esbarra como limite e impossibilidade.

Kinoshita (1996) afirma que "dessa forma, o serviço deve assumir responsabilidade sobre a saúde mental em seu território e a prática desenvolvida pelas equipes deve envolver ações dentro e fora do espaço institucional, conhecendo o território e o cotidiano de cada usuário e explorando ativamente recursos para o desenvolvimento de projetos de vida" (apud MÂNGIA et al., 2002).

Através da estratégia de acolhimento, as instituições podem favorecer a criação de uma nova cultura sobre os tratamentos no campo da saúde mental, contribuindo para a independência dos saberes técnicos e dos espaços institucionais de tratamento.

Quando a equipe assume tal estratégia, assume também a responsabilidade por desenvolver novas concepções sobre o adoecimento e com isso abandonar o repertório de respostas que tendem a "encaixar" a complexidade e a singularidade de 
cada situação existencial nas categorias já conhecidas do serviço que acabam por excluir o usuário quando entendem que ele "não se encaixa".

Tal processo obriga os serviços, assim como os trabalhadores, a deslocarem o objeto de atenção exclusivamente do saber técnico para o sujeito e seu sofrimento, buscando com isso alternativas singulares para cada situação e tendo como conseqüência uma assistência mais humanizada. Também favorece transformações no campo do saber, visto que novas situações geram conflitos que colocam em xeque as concepções pré-estabelecidas inclusive sobre o adoecimento psíquico.

Não queremos dizer com isso que o saber técnico deva ser descartado. Pelo contrário, como destacado na reflexão sobre o trabalho em saúde mental, o saber técnico, o respaldo teórico e os cuidados pessoais são usados nesse momento como argumento de que o trabalho pode se desenvolver com menos angústia e maior segurança quando apoiado pela formação do trabalhador.

No entanto, quando dizemos que o objeto de atenção deixa de ser o saber técnico e se volta ao sujeito, fazemos referência a um determinado discurso de ordem empírica que privilegia, nos primeiros encontros com o usuário, a coleta de dados "que visa dar ao médico a possibilidade de ver o que ele aprendeu a ver, evitando, face a qualquer sintoma ou reação do paciente, qualquer surpresa, qualquer realidade desconhecida”. (BORGES, 2007, p. 205)

Nesse contexto, a proposta do acolhimento é vista como possibilidade de abrir espaço para que o novo possa surgir e seja visto como algo desconhecido pelo trabalhador, mesmo que ele não conte com recursos para abarcar no serviço a demanda trazida pelo usuário.

A esse respeito Mângia et al (2002) dizem:

"O conflito gerado pela relação permanente com a demanda se evidencia, especialmente, nos momentos em que a inexistência de vagas, para inclusão das pessoas nas práticas assistenciais, aparece como uma questão insolúvel. Freqüentemente as equipes optam pelo fechamento das portas da unidade para os 'casos novos', que implica na desresponsabilização diante do que se considera ser apenas falta de recursos institucionais" ( $p .17)$. 
Oferecer espaço para que as pessoas que procuram o serviço possam falar sobre seu sofrimento não implica em assumir mais do que é possível para o serviço, desconsiderando suas limitações, nem tampouco suprir a ausência de outros serviços, mas possibilita que o usuário participe do processo de transformação, se coloque como sujeito frente às questões políticas que implicam no funcionamento dos serviços públicos, gerando inclusive um efeito terapêutico por si só.

Por fim, é importante ressaltar que pessoas com 'transtorno mental', que já vivem num contexto de exclusão, na comunidade da qual fazem parte, no mercado de trabalho e por vezes na própria família, quando encontram serviços que também operam na lógica da exclusão, são colocadas em risco de trilhar um caminho que as levem para um processo de hospitalização ou institucionalização.

A diretriz do acolhimento propõe uma nova lógica de funcionamento, a de inclusão, pois privilegia uma nova concepção de adoecimento, tratamento e do próprio processo de trabalho em saúde. Nessa nova lógica, o objeto deixa de ser a doença em si e dá espaço ao sujeito e suas necessidades, oferecendo instrumentos para a construção de projetos singulares que conjugam saberes técnicos com o da própria comunidade na resolução de conflitos para um possível resgate da saúde.

Como estratégia de organização do serviço, o acolhimento também possibilita a divisão horizontal das relações de poder e valoriza as ações das diferentes categorias profissionais envolvidas, desde o vigia que está atento à movimentação, o pessoal de apoio administrativo que faz o agendamento e matrícula, até o profissional que realiza a escuta de suas queixas. 
CONSIDERAÇÕES METODOLÓGICAS 


\section{OBJETIVO E OBSERVAÇÕES SOBRE O MÉTODO}

Considerando os pressupostos apresentados na introdução, o objetivo do presente trabalho consiste em compreender a natureza dos critérios que norteiam a inclusão de adolescentes em serviços de atenção à saúde mental do sistema público de saúde.

Tendo em vista a intenção de elucidar e compreender o problema em estudo, propõe-se uma pesquisa de natureza qualitativa que tem como objetivo: “(...) apreender um nivel de realidade que não pode ser quantificado. Ou seja, ela trabalha com um universo de significados, motivos, aspirações, crenças, valores e atitudes, o que corresponde a um espaço mais profundo das relações, dos processos e dos fenômenos que não podem ser reduzidos à operacionalização de variáveis". (MINAYO, 2004, p. 21)

Para tanto, optamos por um encontro com a prática em saúde mental através do relato de alguns trabalhadores sobre seu trabalho por meio de narrativas, ou ainda, através do discurso produzido em entrevistas. Através dele, pretende-se refletir sobre a lógica que está em jogo no momento de decisão sobre a inclusão dos adolescentes que chegam ao serviço com uma queixa ou uma questão que pode (ou não) ser entendida como uma demanda de saúde mental.

A fim de tomarmos o discurso como objeto de análise, algumas teorias se colocam como opção metodológica. Não é o caso de estabelecermos as diferenças entre elas para justificarmos nossa escolha, mas de ressaltar que o propósito dessa análise é principalmente de privilegiar os posicionamentos possíveis dos sujeitos entrevistados, considerando sua enunciação como o correlato de certa posição sociohistórica e atravessados por questões subjetivas de ordem inconsciente, numa concepção psicanalítica de sujeito. 
Dentro deste quadro de referências, nossa metodologia se inspira na Análise de Discurso da escola francesa, no entanto, sem a intenção de nomeá-la como tal, tendo em vista que seria necessário um maior aprofundamento dos campos de conhecimento que a compõem, o que não se espera abarcar devido ao recorte que será adotado para esse estudo.

A Análise de Discurso enquanto método que toma o discurso como seu objeto próprio tem seu início nos anos 60 e filia-se teoricamente, em principio, a três grandes disciplinas: a Lingüística, o Marxismo e a Psicanálise. Da Lingüística ela se apropria da afirmação da não-transparência da linguagem, do Marxismo a idéia do materialismo histórico, ou seja, da idéia de que há um real da história, mas que também não é transparente (que em conjunto com a idéia de linguagem se transforma em lingüístico-histórico) e da Psicanálise a noção de sujeito, que se constitui na relação com o simbólico, afetado pelo real da língua e pelo real da história. (Orlandi, 2007)

No entanto, na estrutura desse referencial, outros conceitos se tornam importantes em sua constituição como metodologia complexa de análise, como o conceito de ideologia ou mesmo sistematicidades lingüísticas (ainda que eles sejam tomados em intersecção com outros saberes, como apresentado acima) nos quais optamos por não nos aprofundarmos.

Pretendemos com essa aproximação conduzir a leitura dos discursos produzidos nas entrevistas a partir do pressuposto de que eles estão permeados pelo contexto sociohistórico em que foram produzidos e que expressam posicionamentos subjetivos e próprios, no entanto, sem a pretensão de extrair das falas dos entrevistados alguma verdade que pré-exista ao momento da entrevista e que revele alguma verdade desconhecida.

Para Orlandi (2007), "o que define a forma do dispositivo analítico é a questão posta pelo analista, a natureza do material que analisa e a finalidade da análise". Dessa forma, pretendemos analisar em que perspectivas se constroem os discursos dos entrevistados sobre os critérios de seleção de pacientes, relacionando a 
eles os critérios normatizados pelo discurso da política em vigor assim como seu caminho de formação e de trabalho. 


\section{PROCEDIMENTOS E SUJEITOS}

Tendo como pergunta de partida como profissionais de serviços públicos de saúde mental utilizam elou (re) elaboram critérios para a inclusão de adolescentes nas diferentes modalidades de programas? e escolhido um caminho metodológico para respondê-la, foi preciso definir os procedimentos necessários para que fosse possível entender um pouco mais da prática em saúde mental através daqueles que poderiam nos falar sobre ela, os trabalhadores.

Em primeiro lugar foi preciso escolher uma região de São Paulo, tendo em vista seu tamanho e extensão, para que pudéssemos, a partir deste recorte, mapear os serviços de saúde mental disponíveis e com isso os trabalhadores que, entre outras funções, recebem aqueles que chegam em busca de atendimento em saúde mental.

Partindo do levantamento dos serviços de atenção à saúde mental no município de São Paulo, consideramos os diferentes serviços de assistência à saúde mental previstos pela Política de Atenção à Saúde Mental da Infância e Adolescência (RESOLUÇÃO SS-17, de 19/02/2001), sendo eles: Atenção Básica, Cuidados Ambulatoriais Especializados, Centro de Cuidados Diários (hoje CAPSi), Urgências e Emergências, Residências Terapêuticas e Internação - Enfermarias de Curta Permanência. Lembramos que o documento mais atual que dispõem sobre a assistência em saúde mental infanto-juvenil (ver BRASIL, 2005b) prioriza as ações territoriais e se refere, sobretudo, aos serviços ambulatoriais e do CAPS.

Sendo assim, consideramos os serviços recomendados na Resolução de 2001, complementada pelas idéias propostas no documento de 2005 que por sua vez não dispõe sobre o funcionamento dos serviços, mas sobre os princípios que os regeriam.

Era importante que a região escolhida oferecesse todos os modelos de assistência previstos pela política mencionada acima para que pudéssemos investigar todas as portas de entrada à rede de saúde mental. Seguindo tal critério a região 
escolhida foi a região oeste do município de São Paulo que compreende as coordenadorias de saúde do Butantã e Lapa/Pinheiros, região inclusive privilegiada em termos de oferta de serviços em comparação com outras regiões da cidade.

Nessa região a rede de serviços de saúde mental se desenha, teoricamente, da seguinte forma: os cuidados de atenção básica são oferecidos por Unidades Básicas e Centros de Saúde, os cuidados especializados e de maior complexidade são destinados ao Ambulatório de Especialidades e ao CAPSi e as urgências e emergências ao Pronto Socorro Municipal da região. Os serviços de Residência Terapêutica para crianças e adolescentes não existem na cidade de São Paulo.

Em termos numéricos, de acordo com a lista divulgada no site da prefeitura de São Paulo, são três (03) Ambulatórios de Especialidades, um (01) CAPS infanto-

juvenil, três (03) Centros de Saúde, vinte e seis (26) Unidades Básicas de Saúde e um (01) serviço de emergência psiquiátrica.

\section{Os Serviços}

Tendo como referência a lista de equipamentos divulgada, o primeiro contato foi telefônico para confirmar as informações disponíveis no site.

Dos três ambulatórios especializados divulgados, apenas um conta com serviço de saúde mental, o Ambulatório de Especialidades da região do Butantã, e a equipe desse serviço se dispõe a atender exclusivamente crianças. No entanto, alguns trabalhadores se dispõem a dar retaguarda no cuidado ao adolescente e por isso foram incluídos na pesquisa. 
Quanto aos centros de saúde, dois são coordenados pela Secretaria de Saúde do Estado e um deles pela Santa Casa de Misericórdia ${ }^{6}$, o que exigia outro processo para que pudéssemos conversar com os profissionais. Sendo assim, consideramos o Centro de Saúde Escola Samuel B Pessoa, ou CS Escola Butantã, e o Centro de Saúde Escola Geraldo de Paula Souza, ambos vinculados à Universidade de São Paulo.

Das 26 unidades básicas de saúde, 14 estão localizadas na região do Butantã e 12 na região Lapa/Pinheiros. Em contato telefônico com cada uma delas, verificamos que na região do Butantã apenas 3 unidades dispunham do serviço de saúde mental, mas apenas duas atendiam adolescentes.

No entanto, as duas unidades contam com características bastante diferentes; enquanto uma UBS dispunha de apenas uma psicóloga para atender a demanda de saúde mental de sua região (que se aposentou logo em seguida ao nosso contato), a outra abriga um programa específico chamado PRO-ADOLESC, com uma equipe de 1 assistente social, 1 médica hebeatra, 1 psicóloga e 1 terapeuta ocupacional.

O programa PRO-ADOLESC é descrito por um membro da equipe como:

“(...) programa de atenção integral à saúde do adolescente, que é um programa na secretaria municipal de saúde, está ligado à atenção básica, deveria ter em todos os distritos (coordenadorias de saúde, né, não é mais distrito), mas que, em cada região, a partir do RH e da característica do RH, vai tendo um tamanho de equipe, uma proposta de trabalho diferente".

Em documento elaborado pela área técnica de saúde da criança e do adolescente da secretaria municipal de saúde, o programa PRO-ADOLESC é definido como programa de saúde do adolescente cujo objetivo geral consta como:

\footnotetext{
${ }^{6}$ O Centro de Saúde Escola Barra Funda "Dr. Alexandre Vranjac" foi fundado em 1967 através do convênio entre a Fundação Arnaldo Vieira de Carvalho, mantedora da Faculdade de Ciências Médicas da Santa Casa de Misericórdia de São Paulo; a Irmandade da Santa Casa de Misericórdia de São Paulo e a Secretaria de Estado da Saúde de São Paulo. Por seu vínculo conveniado, o serviço possui um Comitê de Ética próprio ligado à Santa Casa e não à Secretaria Municipal de Saúde, o que a difere das demais. Como as exigências de tempo feitas pelo Comitê de Ética em questão não eram compatíveis como o tempo de pesquisa de campo do trabalho, optamos por retirar o serviço de nossa amostra.
} 
"Promover a atenção integral à saúde de adolescentes de 10 a 19 anos, de ambos os sexos, nas unidades de saúde da Secretaria Municipal da Saúde de São Paulo, no âmbito de uma política municipal integrada, visando à promoção da saúde, à prevenção de agravos e à redução da morbimortalidade nesse grupo etário”. (SÃO PAULO, 2006, p. 5)

A Unidade Básica onde o programa foi instalado também conta com uma equipe de saúde mental, mas de acordo com os trabalhadores entrevistados, toda demanda de adolescente é dirigida ao PRO-ADOLESC. Ainda que o documento não delimite essa função ao programa, encontramos a recomendação, quanto aos recursos humanos, de que a Unidade Básica de Saúde de referência para o programa deve "ter, na Unidade ou em centro de referência, profissionais da saúde mental (psicólogos e psiquiatras) para o atendimento dos adolescentes". (SÃO PAULO, 2006, p. 10)

Já a coordenadoria regional Lapa/Pinheiros, que de acordo com a lista divulgada dispunha de 12 Unidades Básicas, é dividida em Unidades Pólo de saúde mental, ou seja, em algumas Unidades Básicas foram montadas equipes de saúde mental que seriam responsáveis por dar retaguarda às outras da mesma região. Alguns recortes abaixo mostram a definição dos trabalhadores para esse modelo:

"Então, essa UBS é chamada de UBS de apoio, né, então isso é assim, de... uma... a UBS, tradicionalmente, ela faria... trabalha com promoção de saúde, mas como nós somos uma UBS de apoio, isso acabou sendo um misto de Unidade Básica de Saúde e Ambulatório de Saúde Mental (...). Ao todo temos um território de 100 mil habitantes aproximadamente. Então aqui nós recebemos um encaminhamento dos profissionais da UBS Jaguaré, da UBS Parque da Lapa e dessa UBS, né?!"

"Mas ai de novo a coordenadoria pediu que, não eu, alguns psicólogos mudassem, porque ela fez pólos de saúde mental, reuniu os psicólogos todos em algumas unidades (...) para atender a saúde mental da região".

A busca pelo documento que define essa estratégia de "unidades pólo" não foi muito fértil; no entanto, em 2003 o Ministério da Saúde elabora um documento reunindo a coordenação geral de saúde mental e a coordenação de gestão da atenção básica que definem a organização das ações de saúde mental na atenção básica. Uma 
dessas ações é a criação de equipes de apoio matricial de saúde mental às equipes de atenção básica:

\begin{abstract}
"O apoio matricial constitui um arranjo organizacional que visa outorgar suporte técnico em áreas especificas às equipes responsáveis pelo desenvolvimento de ações básicas de saúde para a população. Nesse arranjo, a equipe por ele responsável, compartilha alguns casos com a equipe de saúde local (no caso, as equipes da atenção básica responsáveis pelas famílias de um dado território). Esse compartilhamento se produz em forma de coresponsabilização pelos casos, que pode se efetivar através de discussões conjuntas de caso, intervenções conjuntas junto às famílias e comunidades ou em atendimentos conjuntos". (MINISTÉRIO DA SAÚDE, 2003, p. 4).
\end{abstract}

Quanto ao CAPS infanto-juvenil e o serviço de emergência (prontosocorro), ambos estão localizados na coordenadoria Lapa/Pinheiros e são referência para toda a região oeste. O pronto-socorro dispõe de plantões para atendimento de urgência e uma pequena enfermaria para internações de curta permanência.

Dessa forma foram selecionadas todas as unidades gerenciadas pela secretaria municipal ou estadual de saúde da região oeste de São Paulo que oferecem cuidados em saúde mental para adolescentes. Ao todo temos 10 unidades, sendo elas:

\begin{tabular}{|c|c|c|}
\hline Coordenadoria Regional & Unidade & $\mathbf{N}^{\circ}$ \\
\hline \multirow{3}{*}{ Butantã } & Ambulatório de especialidades & 1 \\
\cline { 2 - 3 } & Centro de Saúde Escola 1 & 1 \\
\cline { 2 - 3 } & UBS/PRO-ADOLESC & 1 \\
\hline \multirow{4}{*}{ Lapa/Pinheiros } & CAPSi & 1 \\
\cline { 2 - 3 } & Pronto-socorro & 1 \\
\cline { 2 - 3 } & UBS (de apoio) & 4 \\
\cline { 2 - 3 } & Centro de Saúde Escola 2 & 1 \\
\hline
\end{tabular}




\section{Os Trabalhadores}

$\mathrm{Na}$ ocasião do primeiro contato com as unidades, ainda através de contato telefônico, além de perguntar se dispunham de um serviço de saúde mental que atendesse adolescentes, também se verificou quem compunha esse serviço, ou seja, quantos e quais trabalhadores faziam parte das equipes de saúde mental.

A partir das informações obtidas nesse primeiro contato, chegamos a um número de 89 trabalhadores, sendo distribuídos da seguinte forma:

\begin{tabular}{|c|c|c|}
\hline Coordenadoria Regional & Unidades & $\mathbf{N}^{\circ}$ de trabalhadores \\
\hline \multirow{4}{*}{ Butantã } & Ambulatório & 5 \\
\cline { 2 - 3 } & Centro de Saúde 1 & 15 \\
\cline { 2 - 3 } & UBS/ PRO-ADOLEC & 4 \\
\hline \multirow{5}{*}{ Lapa/Pinheiros } & CAPSi & 15 \\
\cline { 2 - 3 } & Pronto-socorro & 7 \\
\cline { 2 - 3 } & UBS 1 & 11 \\
\cline { 2 - 3 } & UBS 2 & 10 \\
\cline { 2 - 3 } & UBS 3 & 9 \\
\cline { 2 - 3 } & UBS 4 & 6 \\
\cline { 2 - 3 } & Centro de Saúde 2 & 7 \\
\cline { 2 - 3 } & & $\mathbf{8 9}$ \\
\hline
\end{tabular}

No entanto, para participarem da pesquisa existiam dois critérios:

1. Ter entre suas funções a incumbência de receber os novos usuários no momento em que estes chegam à instituição, estando implicados na decisão de admiti-los ou não no serviço.

2. Concordância e assinatura do termo de consentimento livre e esclarecido (TCLE - em anexo)

Sendo assim, de 89 trabalhadores, 29 foram entrevistados. 
No ambulatório de especialidades, dos 5 trabalhadores, apenas 2 se dispõem a atender os adolescentes, as demais pessoas da equipe trabalham apenas com crianças.

No Centro de Saúde 1, o serviço é organizado de forma que a recepção de novos pacientes é feita pela equipe de enfermagem, sendo assim foram entrevistados 2 auxiliares que aceitaram participar da pesquisa.

Na UBS que abriga o programa PRO-ADOLESC, um profissional não se dispôs a participar e 3 foram entrevistados.

No CAPSi, um profissional de cada categoria profissional foi entrevistado, já que nesse serviço todos são responsáveis pela recepção de novos pacientes. No entanto, das 7 entrevistas realizadas, 1 não pôde ser utilizada pela má qualidade do áudio, totalizando 6 .

O pronto-socorro conta com uma equipe de 7 psiquiatras que se revezam em plantões e destes 7 pudemos conversar com 2, sendo um deles especialista em psiquiatria infantil.

Na UBS 1 da região Lapa/Pinheiros, apesar de contarem com 11 profissionais na equipe, apenas 3 psicólogos fazem a recepção de novos pacientes. Os três foram entrevistados.

Na UBS 2, da mesma forma, o primeiro contato na saúde mental é feito com os psicólogos, mas dos 4 presentes na unidade, apenas 2 atendem crianças e adolescentes e desses 2, apenas 1 aceitou participar da pesquisa.

A UBS 3, que conta com uma equipe de 9 pessoas, atribui a recepção aos psicólogos e à terapeuta ocupacional. Destes foram entrevistados 2 psicólogos e 1 terapeuta ocupacional.

Na UBS 4, igualmente, os trabalhadores responsáveis por receberem a demanda de saúde mental são os psicólogos e terapeutas ocupacionais que totalizam 5 trabalhadores. No entanto, 3 psicólogas se dispuseram à entrevista. 
Por fim, no Centro de Saúde 2, foram entrevistados 1 psiquiatra, 1 psicóloga e 1 psicóloga em programa de aprimoramento profissional, totalizando então 28 entrevistas audiogravadas.

Considerando que "a pesquisa qualitativa não se baseia no critério numérico para garantir sua representatividade... a amostragem boa é aquela que possibilita abranger a totalidade do problema investigado em suas múltiplas dimensões". (DESLANDES apud MINAYO org, 2000).

Nesse sentido são privilegiados os sujeitos sociais que detêm atributos que o objetivo da pesquisa pretende contemplar, considera-os em número suficiente para permitir reincidências das informações, sem desprezar aquelas ímpares (MINAYO, 2004).

A fim de caracterizarmos os trabalhadores que participaram da pesquisa, foram elaboradas as seguintes categorias de descrição:

1. Sexo;

2. Idade;

3. Estado civil;

4. Formação profissional (nesse primeiro momento apenas a graduação ou formação técnica);

5. Tempo de trabalho no serviço público;

6. Tempo de trabalho na unidade;

7. Tempo de trabalho na saúde mental.

Dos 28 entrevistados, a maioria dos trabalhadores é de mulheres (89\%), com idade entre 36 e 60 anos e casadas.

Quanto à formação profissional, temos 11 psicólogos no total de 28 trabalhadores e, considerando o critério de que o trabalhador exercesse a função de receber os novos usuários que buscam o serviço de saúde mental, podemos pensar que essa atribuição é feita na maior parte das vezes a esse profissional, mas também devemos levar em consideração que em muitas equipes o maior número de 
trabalhadores tem formação em psicologia. Os demais trabalhadores se dividem entre 5 psiquiatras, 4 terapeutas ocupacionais, 3 auxiliares de enfermagem, duas assistentes sociais, 1 enfermeira, 1 fonoaudióloga e 1 médica hebeatra. A distinção de atribuições será melhor discutida no processo de análise.

Com relação ao tempo de trabalho no serviço público, a maior parte deles soma de 16 a 30 anos, no entanto, na unidade de trabalho atual, poucos estão há mais de 5 anos. Podemos supor, através de outros dados das entrevistas, que isto se deve à recente inauguração de algumas delas, como o CAPS infanto-juvenil, por exemplo, ou a algumas mudanças na distribuição de equipes de saúde mental realizadas também recentemente, causando remanejamentos dos trabalhadores. Esse aspecto também será abordado a partir de outros ângulos no que se refere à história relatada pelos trabalhadores.

Por fim, quanto ao tempo de trabalho na saúde mental, encontramos uma distribuição menos uniforme. Boa parte trabalha com saúde mental há menos de 15 anos (10 trabalhadores), e destes, 7 estão neste campo há menos de 5 anos. Dos 18 trabalhadores restantes, 17 trabalham com saúde mental de 16 a 30 anos e 1 se diferencia por estar nesta área há 36 anos.

Caracterizando os trabalhadores por tempo de trabalho, seja no serviço público, na unidade atual e/ou na no campo da saúde mental, podemos situá-los em um momento histórico em que ocorreram muitas mudanças.

Dessas mudanças foram privilegiadas a Reforma Sanitária e a Reforma Psiquiátrica, assim como alguns acontecimentos importantes no âmbito da saúde pública no município de São Paulo. Tais acontecimentos foram apresentados na introdução e serão discutidos com os relatos um pouco mais adiante, no processo de análise. 


\section{Aspectos Éticos da Pesquisa}

Antes de entrar em contato com as unidades selecionadas, o projeto inicial desta pesquisa foi encaminhado ao Comitê de Ética em Pesquisa da Secretaria Municipal de Saúde de São Paulo que deu parecer favorável em abril de 2008 (Anexo 1). Então foram recolhidas as autorizações dos coordenadores das unidades e juntamente com o projeto foram submetidos ao Comitê de Ética em Pesquisa da Faculdade de Saúde Pública, também aprovado em agosto de 2008 (Anexo 2).

Após a aprovação, a Supervisão Técnica de cada coordenadoria foi contatada e tendo acesso ao projeto autorizou cada unidade de sua responsabilidade. Aos entrevistados foi dito que a entrevista seria audiogravada e foi apresentado o Termo de Consentimento Livre e Esclarecido (Anexo 3), para conhecimento e esclarecimento, garantindo a confidencialidade, o sigilo e a voluntariedade da participação, respeitando assim as normas estipuladas pela Lei 196/ 96 que dispõe sobre a realização de pesquisas realizadas com seres humanos.

Ainda como importante aspecto ético, foi garantido aos coordenadores assim como aos trabalhadores entrevistados a possibilidade de acesso ao trabalho na íntegra e a possibilidade de uma apresentação através de encontros agendados para discussão dos resultados, caso haja interesse.

Os dados originados no estudo, ou seja, as entrevistas transcritas e arquivos de MP3 estão armazenados e serão mantidos por cinco anos, juntamente com todos

os documentos recomendados pelo Comitê de Ética em Pesquisa da Faculdade de Saúde Pública da Universidade de São Paulo (FSP/USP). 


\section{A Entrevista}

Tendo em vista o objetivo proposto, a entrevista se mostrou como melhor meio de abordar os trabalhadores sobre o tema em questão, considerando que através de um questionário diretivo poderíamos não alcançar com tamanha espontaneidade os depoimentos sobre o trabalho em saúde mental e seus entraves, esbarrando na propensão de um discurso politicamente correto e teórico (o que pode ser minimizado, porém não extinto).

Para auxiliar a condução da entrevista foi elaborado um roteiro temático com os aspectos mais importantes a serem abordados, tendo em vista o objetivo proposto. No entanto, a elaboração desse roteiro não tinha a pretensão de padronizar as entrevistas ou direcionar perguntas estruturadas de igual maneira a todos os entrevistados, mas sim de guiar a conversa para que não deixássemos de fora os pontos mais importantes para a discussão.

Como afirma Schraiber (1995, p. 6), "o modo pelo qual o pesquisador pode intervir produtivamente não tem norma fixa e não se repete de uma a outra entrevista. Não possuindo princípios que de antemão definem o momento e a direção da intervenção, a entrevista conduz sempre a uma atualização do roteiro, fundada na avaliação subjetiva das potencialidades do diálogo".

Os pontos destacados no Roteiro Temático foram divididos em dois blocos: informações para a caracterização dos profissionais e questões norteadoras.

Para a caracterização dos profissionais era preciso constar na entrevista:

- Sexo

- Idade

- Estado civil

- Formação profissional (graduação, pós-graduação, especialização) 
- Tempo de trabalho no serviço público

- Tempo de trabalho na unidade

- Tempo de trabalho na saúde mental

- Funções exercidas no serviço

- Referências profissionais (tipo de leitura, supervisão, educação continuada, etc.)

E como questões norteadoras:

- História profissional e trajetória na saúde mental;

- Quais suas funções dentro da instituição;

- Como se dá a entrada de novos usuários adolescentes na unidade;

- Quais os critérios (oficiais e não oficiais) utilizados para a inclusão de adolescentes no serviço;

- Como ele caracteriza o trabalho em equipe na unidade e qual o papel atribuído a ela na decisão sobre a seleção de pacientes;

- A função das diretrizes e portarias que caracterizam o serviço como parâmetro na hora de selecionar os adolescentes que ingressarão no serviço;

- Percepção sobre o próprio trabalho hoje.

As entrevistas ocorreram nas unidades de trabalho, em horário pré-agendado pelo trabalhador, com o consentimento prévio da coordenação assim como do entrevistado, através da assinatura do Termo de Consentimento Livre e Esclarecido previamente elaborado. A entrevista durou em média 30 minutos, variando de $9 \mathrm{~m} 36 \mathrm{~s}$ a $68 \mathrm{~m}$.

Todas as entrevistas foram iniciadas com a proposta ao trabalhador de que ele contasse sobre sua história profissional. Da história geral ele era encorajado a falar sobre a história no serviço atual e dentro dele suas funções e atividades. Quando mencionada a tarefa de receber os novos pacientes, era solicitado que ele descrevesse o processo de chegada, os procedimentos, a nomeação (triagem, acolhimento, grupo de escuta, etc) e era questionado se em sua opinião os critérios que definem o serviço 
(como CAPS, UBS, etc) ajudam na decisão sobre o destino do paciente (admissão, encaminhamento, etc). Ao final da entrevista era perguntado como ele vê seu trabalho hoje e tal questão tinha como finalidade entender como o trabalhador se situa no processo de trabalho, como ele se posiciona frente a suas funções e atividades.

Embora algumas questões norteadoras da entrevista não respondam diretamente ao objetivo da pesquisa, elas foram propostas para darem margem à questão principal, contextualizando historicamente a fala dos entrevistados, destacando as escolhas feitas dentro de sua história e seu posicionamento frente ao trabalho, entendendo que a compreensão sobre o que é uma questão pertinente ao campo da saúde mental e a formulação de critérios para a inclusão ou não nos serviços não está desvinculada desse cenário político, afetivo e ético do trabalhador. 
PROCESSO DE ANÁLISE 


\section{EIXOS TEMÁTICOS}

Realizadas as entrevistas, todo material de áudio foi transcrito com literalidade e transformado em texto compondo o corpus do trabalho. Em um primeiro momento, cada entrevista foi lida com atenção e a partir dessa primeira leitura foram construídos eixos temáticos, considerando as questões propostas no roteiro temático e ainda temas que se mostraram recorrentes nas falas dos trabalhadores, apontando para novas questões.

Foram definidos os seguintes eixos temáticos:

1. História profissional e trajetória na saúde mental

2. Os meios pelos quais os adolescentes entram na unidade e as formas de recepção

3. Os critérios utilizados para a inclusão de adolescentes no serviço

4. Caracterização do trabalho em equipe na unidade e o papel atribuído a ela na decisão sobre a seleção de pacientes

5. Função das políticas que caracterizam o serviço na decisão sobre a inclusão

6. Caracterização de acolhimento

7. Reflexões sobre a ausência de adolescentes nos serviços de saúde

Os temas "caracterização de acolhimento" e "reflexões sobre a ausência de adolescentes nos serviços de saúde" foram propostos a partir da importância que tomaram nos relatos frente à questão da entrada de adolescentes nos serviços.

A seguir cada um deles será abordado: 


\section{História Profissional e Trajetória na Saúde Mental}

Como tema de análise e discussão, as histórias e trajetórias na saúde mental narradas pelos profissionais entrevistados serão aqui consideradas como contexto sociohistórico de seu discurso, assim como, de um ponto de vista representativo, tornar-se-ão cenário de sua prática, sem o qual entendemos que seu relato perderia a ligação com o próprio sentido de seu trabalho.

A partir de sua formação profissional (seja ela técnica ou universitária), suas especializações, referências teóricas, participação em grupos de estudos ou supervisões, buscamos também uma reflexão sobre a formação e o suporte que profissionais que atuam no campo da saúde mental encontram para nortear sua prática.

Para isso, serão destacados fragmentos das entrevistas que possam ilustrar aspectos importantes para esta discussão acerca do trabalho em saúde mental e mais especificamente nos serviços de saúde mental da rede pública de assistência à saúde, tendo em vista que no relato feito à entrevistadora-pesquisadora o profissional se apresenta como sujeito do discurso. Sendo assim, para preservar essa condição de sujeito e dar voz aos enunciadores, optamos por apresentar a análise através da construção de eixos temáticos que conversem com os próprios enunciadores.

A história que o profissional relata no momento da entrevista, sua própria história, contextualiza seu discurso em um momento histórico assim como margeia suas experiências, dando um sentido único para suas escolhas e suas opiniões.

$\mathrm{Na}$ contextualização histórica do campo da saúde mental, alguns trabalhadores fazem referência ao movimento da Reforma Psiquiátrica como elemento norteador de suas escolhas profissionais. Tal acontecimento coincide com o tempo de formação e de trabalho da maioria de nossos entrevistados, tornando-os, em maior ou menor grau, participantes ou não de sua ideologia. 
Lembramos que a Reforma Psiquiátrica, como descrito na introdução deste trabalho, se caracteriza por um processo de grandes mudanças na forma de pensar e fazer em saúde mental e seu discurso convoca o trabalhador a implicar-se política e afetivamente com a construção de um outro modo de cuidar e entender a loucura.

Algumas falas apenas contextualizam o ingresso do profissional no campo da saúde mental colocando a reforma como pano de fundo:

"Na época da residência eu trabalhei em Santos, na prefeitura de Santos, no PS e num CAPS (no NAPS, né, chamava na época NAPS), foi na época da reforma de saúde mental lá”. (psiquiatra, sujeito 27)

Enquanto para outros foi a identificação com os ideais reformistas que direcionaram suas primeiras escolhas:

\begin{abstract}
"Quando eu soube que ia ter concurso na prefeitura de São Paulo (porque meu sonho era trabalhar no Hospital Dia de saúde mental, né), era aquela fase da reforma da psiquiátrica e hospitais abertos, então a Erundina estava implantando os Hospitais-Dia em São Paulo (foi na gestão da Erundina) eu prestei, passei, fui chamada (...)”. (terapeuta ocupacional, sujeito 4)

“(...) quanto a principal área, mesmo de estágio e de interesse, sempre foi pela saúde mental. Depois que me formei eu logo fui para trabalhar em Santos, na implantação do sistema alternativo no hospital Anchieta de Santos, na área de saúde mental". (terapeuta ocupacional, sujeito 16)

“(...) deste periodo, de 90 - que eu cheguei aqui em São Paulo -, até hoje, eu tenho me dedicado basicamente pro setor público, por me envolver com uma proposta que eu acho que é uma proposta coerente, uma proposta de principios, né, com os quais eu me identifico, que é o da reforma psiquiátrica e a constituição, consolidação do SUS.(...) olha eu ajudei a... a... me convidaram pra participar de fechamento de alguns hospitais psiquiátricos $e$ eu fui ajudar, né, e continuam fechando os hospitais que são muito ruins, né?! Eu vi em muitos lugares, eu vi os pacientes morrerem por maus tratos, morrerem de fome". (psiquiatra, sujeito 26)
\end{abstract}

No conjunto dos relatos podemos identificar posições diferentes como as ilustradas acima. Alguns trabalhadores ingressaram na saúde mental coincidentemente no momento em que eram propostos novos paradigmas e novos 
modelos de assistência, contudo sem um engajamento nesse movimento ou motivados por ele.

Outros relacionam suas primeiras escolhas (ou mesmo todas as escolhas, como é o caso do último fragmento) aos ideais da reforma, buscando através de concursos públicos fazer parte do novo sistema proposto pela reforma em serviços nomeados como HD (hospital-dia), NAPS (Núcleos de Atenção Psicossocial) ou CAPS (Centro de Atenção Psicossocial), todos eles serviços da rede pública de assistência.

No entanto, outras falas indicam uma escolha prioritária pelo trabalho na rede pública e não pelo campo da saúde mental, seja pelo benefício de um vínculo estável, pela identificação com a proposta ou mesmo pela possibilidade de trabalhar com outros profissionais (equipes multiprofissionais). Em alguns casos a permanência no serviço se justifica pela necessidade, por falta de escolha, por curiosidade ou ainda por ter encontrado a possibilidade de trabalhar especificamente com um público de preferência:

"Eu queria, na verdade, entrar na saúde pública, por isso que eu tinha prestado concurso da prefeitura e estava aguardando me chamarem para saúde pública. É... assim que eu fui chamada, então, eu fui fazer a escolha e escolhi a saúde mental, porque eu queria mudar". (enfermeira, sujeito 9)

“(...) eu fiquei muito pouco tempo em consultório. Porque eu acho que tem uma coisa interessante, não que em uma clínica você não possa ter, muitas clínicas têm, mas eu acho interessante essa diversidade de profissionais, sabe? De casos... Aqui também eu peguei uma mudança de gente, gente saindo, gente nova entrando, então isso também é interessante, porque cada um vem com uma nova experiência né?" (fonoaudióloga, sujeito 7)

“(...) na verdade eu prestei o concurso, e de início não era de saúde mental, era de saúde, mas não mental. Mas ai, quando chegou a minha vez, na escolha, já tinham acabado as outras vagas, ai só tinha o ambulatório de saúde mental, ai eu aceitei (risos) para ver como é que era, e aí fiquei na saúde mental". (assistente social, sujeito 11)

"Bom, ai eu tentei tudo o que eu pude para continuar como psicóloga escolar, mas não foi possivel. Nem trabalhar na secretaria de cidadania e assistência social, porque o concurso era 
pra saúde. A gente não sabia, não tava colocado em nenhum lugar... E acabei ficando assim, como psicóloga, trabalhando em UBS, unidade básica de saúde, consultório (...). E claro, a gente vai tentando trabalhar mais perto da casa da gente, então teve remoções oficiais e eu acabei vindo trabalhar aqui, que felizmente é pertinho da minha casa". (psicóloga, sujeito 20)

"Por que que eu prestei concurso? Eu estava em escola, ganhando bem. Concurso eu sabia que ia pagar razoável, mas eu estava provavelmente ganhando mais. Não lembro direito não, mas se não era mais era equivalente. Mas o meu marido teve um diagnostico de câncer que depois não se confirmou, ele ficou bom, fez tratamento e ficou bom, mas eu tinha filhos pequenos, né, e eu falei: "não, eu prefiro ter um emprego efetivo, estável, que eu não possa ser mandada embora, do que ficar numa escola", muito embora eu gostasse bastante, e aí quando eu entrei para a prefeitura eu larguei a escola". (psicóloga, sujeito 17)

"Na área de saúde mental tô trabalhando agora, porque eu nem gostava (risos) (...) eu vim pra cá por força das circunstâncias, porque a minha irmã faleceu e eu tava trabalhando a noite e ai eu teria que passar a trabalhar de dia pra minha mãe não ficar sozinha, né, então o único que eu consegui mais rápido foi na saúde mental". (auxiliar de enfermagem, sujeito 21)

"Sempre preservei esse lado de atender crianças no serviço diário, trabalhando em... e priorizava atendimento em equipe, trabalho em equipe, que não é fácil (risos) você tem que ter suporte pra fazer isso. (...) eu consegui um lugar na prefeitura que tinha uma equipe que se dispunha a trabalhar com criança somente, então foi uma sorte grande, achei que não ia poder continuar a ter essa especificidade, mas consegui, então já estou lá desde 2001 em que eu trabalho só com crianças". (psiquiatra, sujeito 1)

Outros relatam uma identificação com o campo da saúde mental que se deu através do trabalho:

“(...) quando eu estava no final da faculdade eu comecei a trabalhar aqui, e ai eu gostei, né?! Ai eu fui me apaixonando, eu fui estudando e fui ficando. Sempre na saúde mental. Existe uma tem... na época existia uma... uma... uma coisa, uma orientação de que os profissionais fizessem rodizio entre os setores aqui do serviço... e eu sempre fugi dos rodizios (risos). Achei melhor ficar por aqui mesmo". (auxiliar de enfermagem, sujeito 12)

As mudanças no campo da saúde pública e da saúde mental se refletem também nos remanejamentos dos serviços. $\mathrm{Na}$ caracterização dos trabalhadores entrevistados, percebemos que embora alguns estivessem há muitos anos na saúde 
mental, muitos tinham até 5 anos de trabalho na unidade atual e isso pode ser explicado por algumas dessas mudanças:

"E ai era ambulatório de saúde mental, depois falou-se que ia ser o centro de atenção psicossocial, ai depois saiu como centro, aí veio toda a mudança da prefeitura e acabou separando e a gente ficou com o CAPS infantil, e o pessoal do CAPS adulto, que era o antigo hospital, foi pro CAPS onde a gente estava". (assistente social, sujeito 11)

“(...)2 anos e meio atrás eu vim aqui pra essa unidade, né, porque eles desmantelaram o esquema que tinha lá de atendimento em saúde mental, né, e reabilitação. Agora tá só reabilitação. Ai aqui eu fiquei sabendo como é que funciona uma UBS". (psicóloga, sujeito 28)

"Comecei a trabalhar com criança e adolescente, há uns quatro ou cinco anos, cinco anos, até então eu não ficava com as crianças, eu não fazia atendimento de crianças ou adolescentes. Eu comecei a trabalhar com essa população quando formou aqui, né?! Na verdade a gente não teve muita opção, porque a gente era do Estado e se formou o CAPS infantil, e a gente acabou tendo uma opção de escolha, mas ou era aqui (risos) ou ia para o outro lugar, então eu acabei vindo para cá”. (assistente social, sujeito 11)

"Mas ai de novo a coordenadoria pediu que, não eu, alguns psicólogos mudassem, porque ela fez pólos de saúde mental, reuniu os psicólogos todos em algumas unidades (...)para atender a saúde mental da região. Era uma organização diferente. Por mim eu estava muito bem onde estava, mas eu vim porque você tem que vir, né? Eles falaram: "olha, você vai mudar, você tem esse local e aquele outro para ir", né? Ai eu já estava mais velha, com mais tempo de prefeitura, até fui a primeira a escolher e escolhi vir para cá (...). Há dois anos e pouco”. (psicóloga, sujeito 17)

"Então, aí.. vir pro CAPS não foi uma opção, porque eu voltei da licença gestante em 2006, já havia mudado de administração, tava começando o prefeito atual, né? Era a Marta, e passou um tempinho, "olha, não vai ter mais reabilitação aqui", porque na verdade já não funcionava direito mesmo, não tinha espaço, mas tinha fono, TO, ta? (...) Então tem essas coisas que deixam a gente meio louca às vezes, né? Ai, no começo eu vim meio assustada, entendeu? Porque eu tinha uma noção de CAPS num lugar muito dificil, né, pesado... entendeu? (...) E eu trabalhei com autista no primeiro ano de formada, não sabia nada, ai eu fiquei horrorizada né?" (fonoaudióloga, sujeito 7)

É importante observar que algumas falas apontam para uma imposição da mudança, não para escolhas. Nesses casos a maioria dos entrevistados se posiciona 
de forma passiva, não tomando parte como sujeito ativo no processo de transformação nos modelos de assistência.

No entanto, quando fazem referência às mudanças impostas pela implantação do PAS (Plano de Atendimento à Saúde), na gestão de Paulo Maluf (de 1993 a 1997), relatam um posicionamento político ativo, definindo inclusive outros remanejamentos no trabalho, tendo em vista que aqueles que não aderiam ao plano não podiam permanecer na área da saúde.

“Na época do PAS (...) quem não aderiu ao plano saiu da saúde, não podia ser mandado embora, como eu não aderi eu fui transferida pra Secretaria de Esporte, pra uma unidade esportiva, Centro Educacional Esportivos, e ai lá eu fiquei 5 anos afastada da saúde mental, só trabalhando com a terceira idade, né?Então, quando a gente voltou para a saúde na época da Marta, que ela trouxe de volta o pessoal da saúde, eu pedi: "olha, eu não quero voltar pro Hospital Dia, eu quero ir para um lugar onde eu possa trabalhar na linha mais preventiva ou de tratamento, mais assim, coisas mais amenas mesmo, acho que deu o meu tempo de casos mais graves de psiquiatria". Ai vim para cá faz uns 8 anos que eu estou aqui na UBS, né?" (terapeuta ocupacional, sujeito 4)

“(...) na época do PAS, quando o PAS entra na região, ou você ia para lista de Schindler - que a gente chamava, que era para o projeto de AIDS, que era uma verba governamental, do governo Federal - ou depois de um determinado tempo, e eu cheguei a participar disso, a gente era destinados a alguns programas de prevenção à saúde, então, era trabalhar com idoso na comunidade, então atividades físicas, palestras, grupos nas igrejas, nos parques, enfim, a gente fazia, então... quer dizer, não era tão especifico na saúde mental". (terapeuta ocupacional, sujeito 16)

“(...) foi quando voltou às prefeituras, né? E teve a implantação da gestão plena, no município, voltou... acabaram com toda aquela loucura do PAS, e começou a retomar algumas unidades, começaram a retomar uma unidade que era o Hospital Dia de Saúde Mental do Butantã, né, que tinha ido pra Lapa na época do $P A S$, tinha ficado toda a saúde mental que tinha na região da Lapa, Butantã não tinha nenhuma unidade de referência, né, de especificamente saúde mental e ai, com a volta do SUS realmente, efetivamente na cidade de São Paulo, eles foram retomando algumas unidades e tentaram trazer de volta o Hospital Dia para a região do Butantã. Eles estavam montando uma equipe, e nesta época eu mudei de onde eu estava para a região Oeste. Fiquei sabendo da vaga, disse da minha vontade de voltar para a Saúde Mental, né? Que é uma coisa que eu sempre quis fazer (risos) e, ai 
me chamaram. Comecei a trabalhar no HD do Butantã que depois virou CAPS de adulto (...) no orçamento participativo de 2003 pra 2004 foi votado lá na região do Butantã, votaram num CAPS de adolescente (...) a coordenadora de saúde da região centro-oeste, me chamou para montar a equipe, pra montar o CAPS adolescente (...)A idéia era compor a nossa equipe de adolescentes com a de infância, e ai a gente foi transferido para o ambulatório de especialidades". (terapeuta ocupacional, sujeito 2)

“(...) com a entrada do PAS, eu fui remanejada para vários locais e acabei parando no CS1 (Centro de Saúde) de Pinheiros e fui trabalhar na Casa do Adolescente e de lá para cá eu venho trabalhando com adolescente". (médica hebeatra, sujeito 15)

Ainda outros motivos são mencionados nos relatos para a presença na unidade atual de trabalho, como transferência para locais mais próximos da residência, da escola dos filhos e, em alguns casos, pela preferência de trabalho.

“(...) por conta dessa questão de abuso sexual e tal, eu tive caso de dois pais que foram lá e tal, ameaçando com revolver (...) com esse problema de ameaças, a supervisão de saúde de lá acabou me colocando no CAPS de adulto. E ai eu fiquei no CAPS, eu não tinha tanta experiência com esquizofrenia, com o tratamento mais mesmo... né, de uma doença mental mais severa... né?(...) Eu estou aqui nessa UBS vai fazer 5 meses, é muito recente. Eu consegui uma transferência para cá”. (psicóloga, sujeito 5)

"Para cá eu vim em remoção zerada, justamente, que foi o meu luto lá pra passar para cá (risos). Eu aproveitei que a Erundina fez a remoção zerada e ai eu tinha como escolher o melhor lugar, $e$ o melhor lugar para mim era aqui, porque elas [filhas] estudavam aqui do lado. Isso foi... deixa eu tentar lembrar... em 92, é em 92 eu acho, um pouco antes do PAS. E ai quando entrou o PAS eu não aderi ao PAS". (psicóloga, sujeito 6)

“(...) eu poderia ter escolhido nesta região, trabalhar no CECCO, trabalhar em CAPS, trabalhar... mas eu preferi trabalhar na UBS, eu acho que eu gosto de ser generalista, eu acho que quando a gente vem trabalhar aqui, a gente é generalista, eu me adapto bem”. (psicóloga, sujeito 20)

É importante ressaltar que a maioria dos trabalhadores entrevistados, embora façam parte da rede de serviços da região oeste de São Paulo, já trabalharam em outras regiões da cidade. Eles se referem à impossibilidade de escolha no ingresso no serviço público, tanto de região como de serviço, e que vão aumentando essa possibilidade conforme acumulam tempo de trabalho. 
"Comecei na prefeitura em fevereiro, fevereiro de 1990. Comecei num Centro de Convivência e depois, na zona sul, era longe da mina casa, mas era onde... ou era zona leste ou zona sul, quando a gente entra é assim, você não vai para o lugar que você quer, você vai onde tem vaga. Depois de 2 anos teve uma remoção zerada (...)”. (psicóloga, sujeito 17)

As "remoções zeradas" citadas em algumas entrevistas dizem respeito a política que teve grande impacto sobre os técnicos no final da gestão Erundina, de 1989 a 1993 que será discutida mais adiante.

"Remoção zerada é assim: todos os cargos de psicólogos estão à disposição e quem é mais antigo, mais titulado, escolhe primeiro, então as pessoa podem mudar de lugar". (psicóloga, sujeito 17)

No entanto, esses acontecimentos políticos fazem parte da história dos trabalhadores que compõem esse estudo e essa história, como forte argumento em todo o trabalho, acarreta em particularidades no seu modo de fazer e entender o trabalho em saúde mental.

Para além dessas experiências coletivas de mudanças nos serviços, também encontramos em seus relatos informações sobre escolhas de formação complementar, apontando necessidades encontradas no trabalho cotidiano, preferências teóricas e limites que pretendem superar:

"Eu fiquei 7 anos fazendo essa especialização só em saúde mental, mas hoje em dia eu sinto a falta de outras áreas, principalmente por conta das crianças que aparecem aqui com dificuldade de aprendizagem. Precisaria ter uma... eu estou buscando complementar a historia, né? (...) como eu sou a única TO não tem muito como escapar, o que aparece eu tenho que estar me virando. As psicólogas ainda conseguem porque uma atende mais adultos, a outra mais adolescentes, a outra mais crianças e eu não tenho muita escolha não". (terapeuta ocupacional, sujeito 4)

“(...) eu mudei pra São Paulo, onde eu vim fazer uma especialização em saúde pública. Depois fiz o mestrado, eu fiz saúde pública pela Faculdade de Saúde Pública da USP e fiz o mestrado pela Faculdade de Medicina, também da USP, pelo departamento de Medicina Preventiva”. (psiquiatra, sujeito 23)

"Tenho especialização em saúde mental, que eu fiz na época que eu trabalhava com adulto. Na infância e adolescência, específico, eu não tenho. Tenho especialização em saúde mental que eu fiz lá 
pela USP, pela faculdade de enfermagem e pelo CAPS Itapeva". (assistente social, sujeito 11)

“(...) eu pensei assim: “(...) mas eu vou ficar fazendo isso a vida inteira? O mesmo tipo de coisa? Deixa eu ver se eu mudo um pouco. Ai eu resolvi fazer a especialização da Faculdade da Saúde Pública. Era o governo Erundina, e eu consegui, fui uma das últimas pessoas que conseguiu fazer o curso, eu consegui ter uma licença sem perder os vencimentos, então eu fiz o curso, que era na verdade de manhã e à tarde, era um curso mais intensivo, ganhando o meu salário". (psicóloga, sujeito 20)

"eu fiz especialização em saúde pública, depois e por intermédio da prefeitura, fora do horário de trabalho, mas foi a prefeitura que ofereceu, ela fez um convenio com a USP, com a Faculdade de Saúde Pública, e a gente prestou concurso e os que passaram foram fazer o curso de saúde publica no CEFOR, que é o centro de formação da prefeitura, e eu fiz”. (psicóloga, sujeito 17)

Mas também dificuldades e impedimentos, como falta de tempo, de financiamento e de apoio do governo.

"Então fica dificil. A gente acaba, a maioria dos profissionais aqui trabalham em dois lugares, são raríssimas as exceções aqui e, principalmente, quem é do Estado. Eu sou do Estado e sou municipalizada, então a gente tem um salário que é diferente do que o da prefeitura, então é complicado mesmo, então você chega em casa super cansada, não dá conta, gostaria muito, mas quando tem um mais em conta aí eu vou, mas é difícil. Mas é coisa de simpósio, coisas bem mais simples, não de formação". (terapeuta ocupacional, sujeito 8)

"Eu fiz alguns cursinhos rápidos, não fiz ainda a especialização que eu estou pretendendo fazer, mas ainda não foi possivel, porque, como eu te disse eu tenho outro trabalho, né, trabalho no noturno, num hospital geral, e durante à tarde, todas as tardes aqui (...). Então eu pretendo fazer essa especialização em breve, mas ainda não foi possivel". (enfermeira, sujeito 9)

"Fiz, de linguagem. Quer dizer, fiz, mas eu não completei porque eu tava para ganhar nenê (...)comecei a fazer, fiz 1 ano e meio, faltava pouco, né? Mas como eu ia ter neném em setembro de 2005, eu resolvi fechar no meio, em julho, para depois terminar no outro semestre. Ai por questões, né, "agora já não é mais um filho, são dois" sabe? Um adolescente e uma pequenininha. Claro que a gente vai priorizando, mas assim, eu fui priorizando outras coisas, entendeu? Porque eu precisava ter o dinheiro para aquilo, né? Eu acabei não voltando (...)”. (fonoaudióloga, sujeito 7) 
Alguns ainda se valem da prática como elemento de formação continua, afirmando que aprendem com o trabalho do dia-a-dia e no contato com os pacientes:

“(...) a minha formação, então, não é especifica por titulo, é só na prática mesmo (risos), na prática que a gente tem... que eu estou desde 95 trabalhando com adolescentes". (médica hebeatra, sujeito 15)

"Então eu entrei no CAPS infantil, há 4 anos e meio atrás, não faz muito tempo e... foi no CAPS infantil que eu fui aprendendo, no dia a dia, o trabalho mesmo que é desenvolvido". (enfermeira, sujeito 9)

E outros apontam a insuficiência da formação dos cursos técnicos ou universitários para o trabalho em saúde mental:

"Pra mim foi muito importante, as especializações que eu fiz (...). Eu acho que foram super importantes para mim, porque eu sai muito crua da faculdade". (terapeuta ocupacional, sujeito 2)

"Não, não, eu fiz o curso de técnico de enfermagem em 2... no ano 2000, é, foi 2000 e o curso é curto, né, é 8 meses de duração e e agente fez um estágio no Hospital Pinel, mas também acho que deve ter dado 13 dias, 15 dias no máximo". (auxiliar de enfermagem, sujeito 21)

Assim sendo, outro aspecto importante referido pelos trabalhadores quanto à sua história e trajetória de trabalho é a possibilidade de contar com apoio de supervisão, e quanto a isso eles apontam a ausência de apoio financeiro do governo e as saídas encontradas:

“(...) eu tenho uma supervisão há 21 anos pela prefeitura com dois psicanalistas da sociedade e tudo mais. Eles não são assim ortodoxos, já tinham trabalhado no serviço publico, eles conhecem as problemáticas, eles conhecem toda a necessidade que a gente tem de adaptação, de uma série de coisas à situação do serviço público então a gente criou muita coisa, o jeito de atender, formas de entender as pessoas". (psicóloga, sujeito 19)

"A gente está pagando supervisão, sai do bolso". (assistente social, sujeito 11)

“Atualmente pra prefeitura a gente não tem... a gente tem essa supervisão, que na verdade (...) a gente faz mensalmente de saúde mental, então nesse espaço a gente, não só a gente, né, mas os profissionais da região levam casos e a gente discute (...)Então a gente tem esse espaço de discussão, o que eu acho super 
importante, porque a gente, inclusive, discute a articulação da rede para os atendimentos". (terapeuta ocupacional, sujeito 2)

“(...) Na época que eu engravidei, eu estava... além de fazer terapia eu fazia supervisão bancada por mim, né? Dos casos que eu atendia na prefeitura, evidentemente, mas era uma supervisão bancada por mim ai por conta do financeiro, correria com filho, essa coisas, casa, serviço, né? Ai eu tive que parar por um bom tempo (...)". (terapeuta ocupacional, sujeito 2)

"Nós também conseguimos - já faz tempo isso - uma autorização pra gente fazer uma supervisão, que é semanal, cada 15 dias com uma pessoa, sendo que uma é uma psicanalista que trabalhou também em coisas outras, no ministério da saúde, que tem muita experiência em questões da saúde pública, né?(...) Então a chefia autoriza a saída, tá até questionando o horário e tal, mas não tem questionado, a gente tem sempre conseguido autorização para sair, porque valoriza, porque acho que ajuda a discussão de casos, e é super sério. Enfim, isso ajuda, né?!" (psicóloga, sujeito 20)

"Então no começo, eu tinha a minha supervisão, não sei se as colegas falaram que a gente tem também aqui supervisão, é uma supervisão semanal, às sextas-feiras, uma sexta-feira é com um psiquiatra que a gente paga, é uma supervisão paga, paga por nós, né? E outra vez é por uma psicóloga, a M.F., psicanalista, uma senhora excelente, super experiente, professora universitária; esta, ela faz de modo voluntário, então a gente vai à casa dela, apresenta um caso, discute, nós todas e ela... é muito bom, e com o psiquiatra também é muito bom, é no consultório dele. Então... é só para quem quer, não é uma atividade oficial, obrigatória (...)”. (psicóloga,sujeito 17)

"A gente faz aqui. Isso foi há pouco tempo, parece que de agosto, as pessoas estavam falando, não tenho certeza se foi em agosto. A gente tava percebendo, a equipe, que tinha uma necessidade de aprofundar os casos, sabe? E casos assim, a gente precisava discutir mais para objetivar, chegar numa... se aproximar de um diagnóstico, porque se você for ver muitos, né... vão mudando. Ai até que veio uma psicóloga, veio outra, pra gente ver de quem gostava... com quem a gente se identificava mais, acabou acho que começando no segundo semestre. A principio são duas sextas por mês, agora dia 31 tem, e está participando basicamente todo mundo, (...) nós vamos discutir justamente com ela essa questão (risos), assim, porque ai tem que ficar revendo o preço, é meio complicado". (fonoaudióloga, sujeito 7)

A necessidade de suporte técnico é recorrente nessas falas que são imbuídas de queixas frente à falta de apoio do governo e à necessidade de pagar por conta própria. 
Muitos trabalhadores fazem referência aos mesmos profissionais que se dispõem a oferecer supervisão voluntariamente ou por valores simbólicos, supervisões mantidas nessas condições, em alguns casos, há mais de 20 anos.

Assim como a formação complementar, a iniciativa de buscar apoio parte dos profissionais que pleiteiam autorização para saírem da unidade durante o tempo de trabalho em busca de auxilio através de supervisão.

Esse eixo temático aponta então para alguns acontecimentos históricos que aparecem no relato dos trabalhadores entrevistados, margeando suas escolhas e frente ao qual se posicionam oras de forma ativa, oras passivamente, apontando alguns aspectos políticos de ressonância ao trabalho e outros enrijecedores.

Aponta ainda para a importância dada à formação e seus entraves no cotidiano, destacando um ponto importante para a discussão deste trabalho, tendo em vista considerarmos a importância da bagagem do trabalhador, seja ela política, afetiva e/ou técnica, na prática de seu trabalho e nas escolhas feitas dentro dele.

\section{Os meios pelos quais os Adolescentes entram na Unidade e as Formas de Recepção}

Neste eixo de análise, procuramos identificar, a partir dos relatos nas entrevistas, o caminho percorrido pelos novos usuários na chegada aos serviços de saúde mental, em especial os adolescentes, caracterizando dois aspectos deste percurso: "como eles chegam" e "como eles são recebidos".

A intenção deste eixo é lançar luz sobre o fluxo de encaminhamentos e as redes erigidas no trabalho que garantam (ou não) o acesso ao serviço. Considerando os diferentes modelos de atenção contemplados no estudo, sendo eles o modelo de 
atenção básica (Centros de Saúde e Unidades Básicas), o modelo ambulatorial (serviço de saúde mental do ambulatório de especialidades), o dispositivo do CAPS (como centro de atenção diária) e o recurso de pronto socorro (que inclui uma enfermaria de curta permanência), torna-se necessário distingui-los em sua organização para a entrada de novos usuários tendo em vista que cada um por definição desempenha uma função diferente na rede de atenção em saúde mental.

Dessa forma, optamos por não nomear os sujeitos das falas destacadas para esse eixo de análise (pela necessidade de diferenciar as unidades), uma vez que elas identificam seus enunciadores e podem ferir nosso compromisso de sigilo.

Comecemos então pelo tópico "como eles chegam" à unidade e para ilustrar o fluxo de chegada, apresentaremos diagramas construídos a partir das falas de nossos entrevistados. Para isso serão utilizados os termos empregados pelos próprios trabalhadores (como demanda espontânea ou procura espontânea), que não necessariamente concordam com os termos empregados e conceituados em nossa introdução.

\section{UBS 1}

No caso dessa UBS, os trabalhadores relatam diversas fontes de encaminhamento que configuram o modelo de atenção básica como porta de entrada para as questões de saúde mental do território, ou seja, os usuários chegam a partir de outras Unidades Básicas de Saúde da região, algumas delas caracterizadas como unidades de PSF (Programa de Saúde da Família), por trabalhadores de outros programas do mesmo serviço, como o médico pediatra e o clínico, e também por recursos da comunidade, no que se destaca a escola.

Então aqui nós recebemos um encaminhamento dos profissionais da UBS Jaguaré, da UBS Parque da Lapa e dessa UBS, né. O encaminhamento é feito pelas escolas, no caso das crianças e adolescentes, pelas escolas, pelos médicos pediatras, né, pelos clínicos; no caso do programa de saúde da família, pelos profissionais do programa de saúde da família, que é a UBS 
Parque da Lapa e aqui na nossa UBS a gente aceita também a procura espontânea, né, o pac... o que é matriculado aqui.

Eles vêm encaminhados, né, pelo médio e.. ou pela escola. Às vezes a procura é espontânea: eles mesmos querem ou a família insiste, eles voltam, mas em geral eles vêm a partir da... de um olhar externo, né. Acontece de ter procura espontânea, eu mesma já atendi, mas não é tão comum.

Eles chegam encaminhados pelos médicos, né, ou pela escola, geralmente. A principal demanda, principalmente pros adolescentes, é da família, é difícil o próprio adolescente procurar.

Também aparece o que eles nomeiam como procura espontânea, que podemos entender como a procura do próprio adolescente, diferenciada da procura por parte da família, que aparece como fonte importante nesta unidade.

O diagrama a seguir ilustra as fontes de encaminhamento citadas acima:

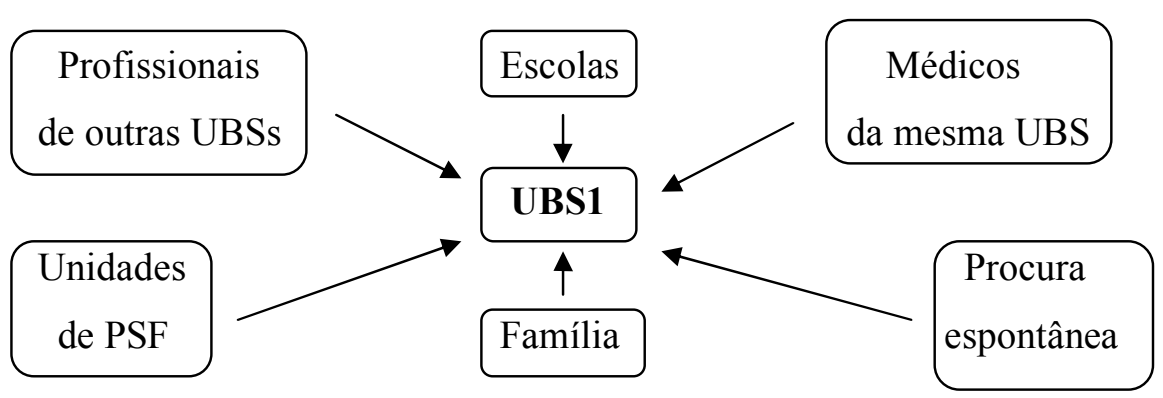

\section{UBS2:}

Essa UBS, da mesma forma que a anterior, aponta como fontes encaminhadoras trabalhadores da mesma unidade, como o pediatra, trabalhadores de outras Unidades Básicas da região, a escola como representante dos recursos da comunidade e a chamada demanda espontânea.

Então, as pessoas vêm para essa unidade encaminhadas. Ela pode ser por demanda espontânea, pode ser pra saúde mental por encaminhamento dos profissionais da UBS ou de outras UBSs, a gente atende aqui 3 regiões (...).Adolescente mesmo a demanda é de uma escola que tem ensino fundamental dois e ensino médio. Mas é bem pequena a procura, principalmente de ensino médio. Então assim, que chega de procura é demanda espontânea, que parte deles mesmos a procura. Agora, a maior parte é encaminhamento do pediatra, mais de criança e... doze, treze anos, 
até treze anos. Ou é do pediatra ou é pedido da escola em função de dificuldade de aprendizagem.

No entanto, observamos aqui uma caracterização não muito clara a respeito da chegada de adolescentes na unidade, uma vez que primeiro é dito que eles chegam encaminhados e logo em seguida que a procura é espontânea.

Quanto ao encaminhamento proveniente da escola, a maior parte é referida ao ensino fundamental assim como o encaminhamento do pediatra dos mais jovens, situados entre doze e treze anos. Esses, segundo a fala acima, são os que mais chegam ao serviço, principalmente em função de uma queixa da escola de dificuldade de aprendizagem.

O diagrama abaixo representa as fontes citadas:

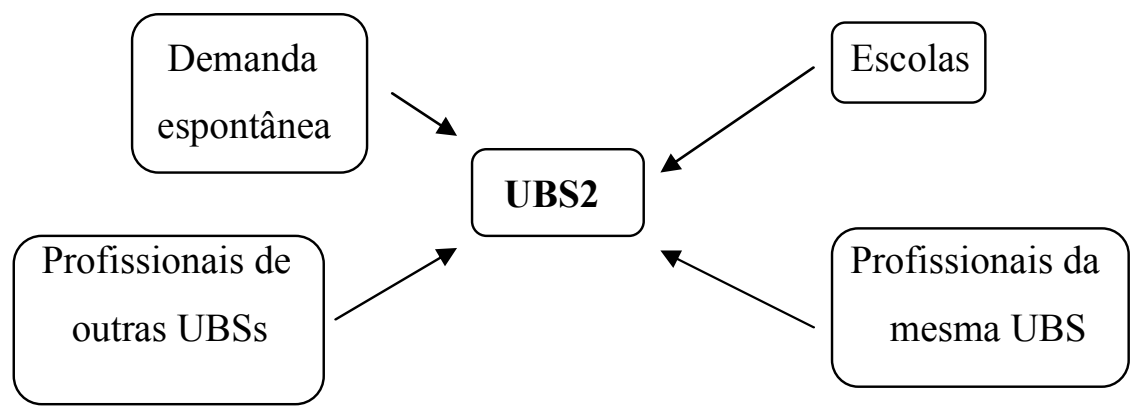

UBS 3:

Essa unidade, no caso, assim como as outras recebe os adolescentes que chegam espontaneamente (demanda espontânea), por encaminhamentos internos ou de outras instituições que não são nomeadas.

Pode vir um encaminhamento interno, pode vir uma demanda espontânea (...) a escola manda ou uma outra instituição manda (...) vamos supor, a psiquiatra quer que eu atenda um caso que ela tá acompanhando, ela vem diretamente comigo e fala: "olha A., eu tenho um caso assim, assim e assado", dá pra você atender, então eu marco uma triagem direto com aquele paciente... individual, não vai para o grupo, né? 
(...) mas aqui o que eu vejo, assim, eu tenho alguns adolescentes que eu atendo, que são três, dois já diagnosticadas, já vieram diagnosticadas pelo Hospital das Clínicas com depressão, fazendo tratamento com o psiquiatra (...) temos o CAPS aqui perto, e o CAPS, quando o paciente está legal, está compensado, vem para a gente, que a gente ficou como referencia deles e eles da nossa (risos).

Diferente das outras unidades analisadas acima, esta cita o CAPS como fonte de encaminhamento para quando o paciente está "compensado", ou seja, para dar continuidade ao tratamento e não para iniciá-lo.

Como aspecto peculiar, as falas dos trabalhadores desta unidade apontam para uma "troca" entre trabalhadores no ato do encaminhamento, seja dentro da mesma unidade (como aponta a primeira fala), seja na troca de referências com outras unidades (como enuncia a segunda).

O diagrama abaixo também ilustra as conexões:

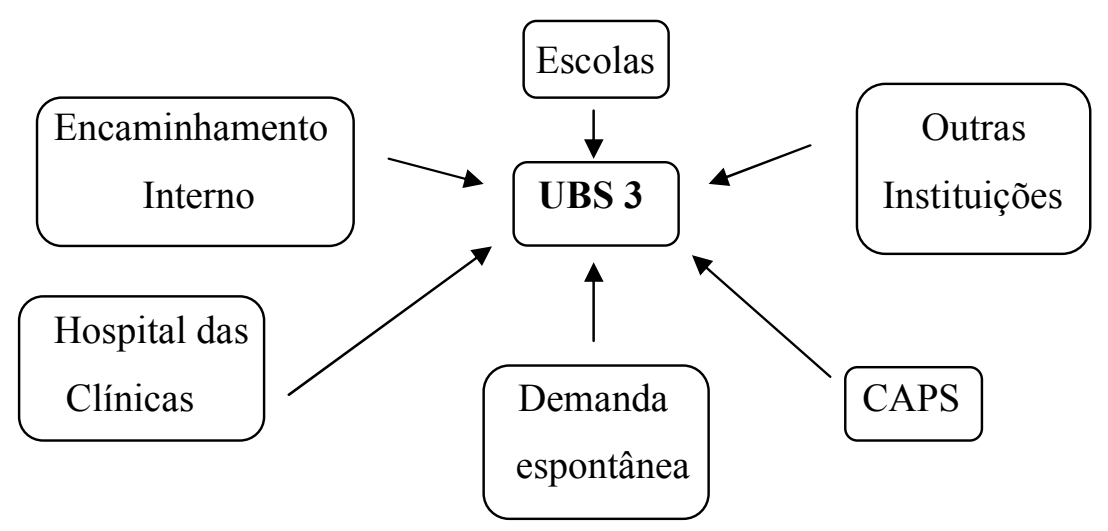

\section{UBS 4:}

Como nos relatos anteriores, nesta unidade os encaminhamentos partem de dentro (pediatra, assistente social, outros médicos) e de fora, no caso as escolas. Também referem uma procura espontânea do adolescente, mas identificam os pais como maiores solicitadores de atendimento.

Vem tudo junto. Adolescente o pediatra pode-porque até 18 anos eles vão ao pediatra - o pediatra pode nos encaminhar, acontece. Acontece da assistente social encaminhar uma mãe que vai, que 
reclama da filha, e ai a assistente social pede para a gente fazer uma avaliação. Outros médicos daqui, todos eles encaminham, e uma procura espontânea, né, "acho que eu preciso de um psicólogo", e essa procura espontânea ... escola, a escola pede muito uma avaliação, ainda mais que tem uma escola ao lado, é muito comum vir cartinha da escola pedindo avaliação, psicoterapia para as crianças, né? Os jovens: mais os pais que solicitam.

Encaminhamentos internos também, então qualquer profissional que queira conversar com a saúde mental, queira encaminhar o paciente para saúde mental, encaminha para o acolhimento, né?! (...) Agora, a gente seleciona muita gente também, pra saúde mental na verdade, nos grupos de gestantes, se você conversa com as gestantes você percebe quando ela está precisando de uma conversa mais longa, se ela está precisando fazer uma avaliação, conhecer melhor aquela pessoa (...)

Diferente das unidades analisadas até agora, nesta aparece uma busca ativa por parte dos trabalhadores de saúde mental que selecionam possíveis pacientes nos grupos de gestantes, através da observação das mesmas nos grupos específicos sem que haja um pedido ou procura por parte delas, o que identificamos no diagrama abaixo como "busca ativa".

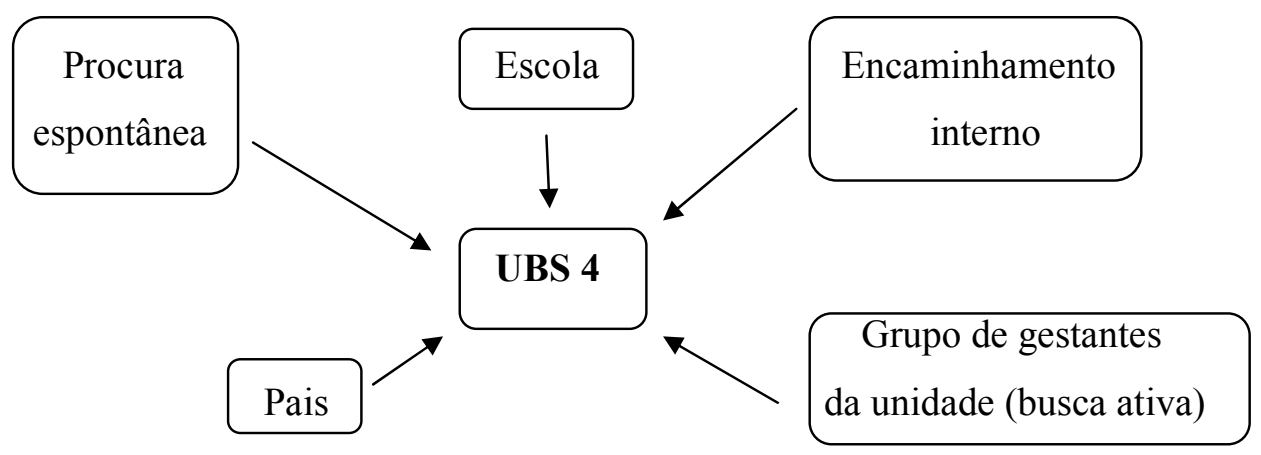

\section{UBS/PRO-ADOLESC}

No caso desta unidade, sua característica principal é acoplar os modelos de Unidade Básica com o de um programa destinado especificamente aos adolescentes. No entanto, quanto às fontes de encaminhamento e formas de chegar ao programa, ele em nada se distingue das Unidades Básicas comuns. 
Bom, eles chegam... Então o que a gente tem? Muitos adoles... alguns adolescentes institucionalizados, né; nós temos adolescentes que chegam porque já eram pacientes dos pediatras e ai chegou com 10 anos e os pediatras vão encaminhando(...) as escolas encaminham, né; e... acho que é interessante, que há uma demanda também espontânea, que as mães vêem o movimento dos pacientes que estão na unidade, né, os adultos, então "eu posso trazer o meu filho?" Vem aqui conversar na porta, "posso trazer? Ele está assim e assim e assado".

(...) se a psicóloga de outro posto mandar um adolescente que gostaria que fizesse parte de um grupo de adolescentes aqui comigo, porque sabe do trabalho, ou gostaria que passasse, entrasse, tivesse uma entrada, ela sabe que ela pode mandar naquele horário, que tem a possibilidade de encaixe.

(...) através de mim, às vezes vem mães, vem mães ou pais, mas normalmente vem a mãe com a queixa do adolescente que está indo mal na escola ou algum outro tipo de questão, de drogas... foi mais isso que chegou pra mim (...)

Aqui o que aparece de novidade é o encaminhamento de instituições como a Fundação Casa e de abrigos, o que pode ser justificado pelo território no qual está inserida do qual também fazem parte essas instituições, diferente das demais, o que percebemos mais claramente na ampliação do diagrama.

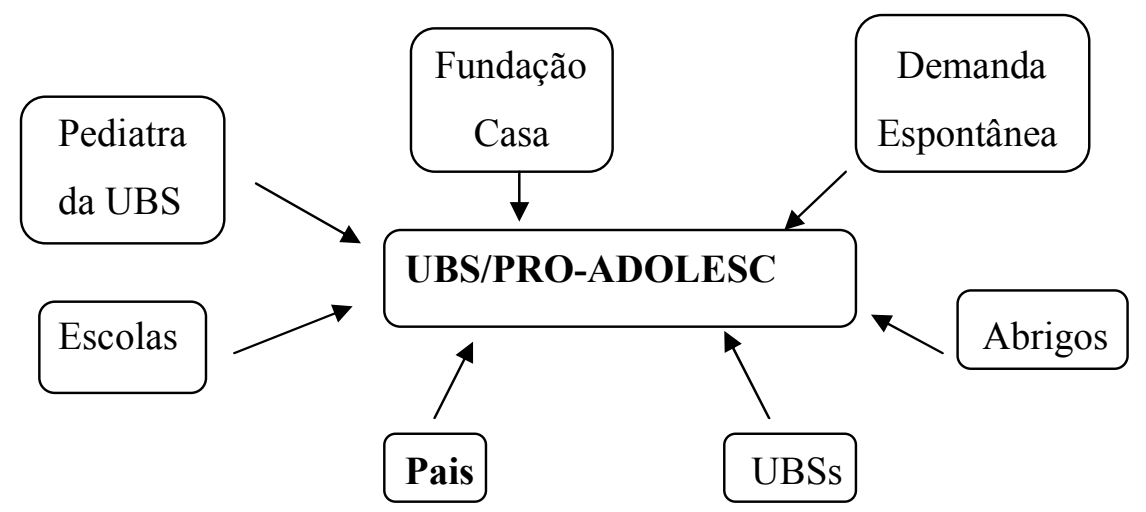

\section{CSE 1}

O Centro de Saúde 1, serviço que também faz parte do modelo de atenção básica, é caracterizado aqui por fontes de encaminhamento semelhantes às Unidades Básicas de Saúde, no entanto, aponta um número reduzido de conexões externas, referindo a procura pelo serviço de saúde mental por parte de outros programas da mesma unidade, por pais já usuários do serviço e por uma procura espontânea. 
Mas a gente tem, por exemplo, pacientes nossos, nossos pacientes que estão, às vezes, com problema com filhos, né, e trazem; outros vêm encaminhados do programa da saúde do adolescente, da saúde do adulto e outros procuram espontaneamente, né?!

Mais uma vez, ilustramos essas conexões em um pequeno diagrama:

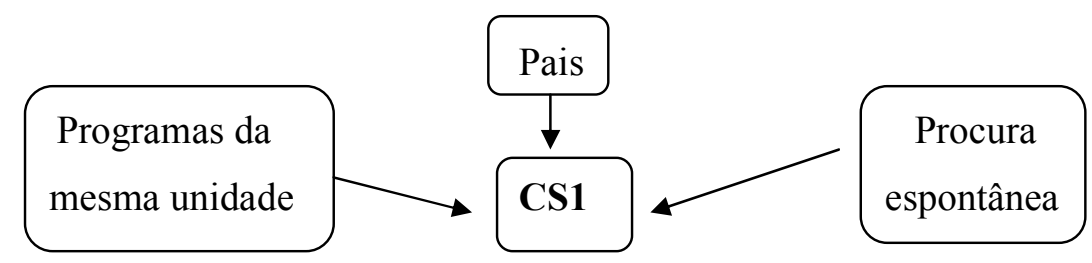

\section{CSE 2}

Da mesma forma, o Centro de Saúde 2 também não se refere à encaminhamentos provenientes de outras instituições ou de recursos da comunidade, indicando apenas a uma demanda espontânea e o encaminhamento de outros médico, supostamente do mesmo serviço. O diagrama ilustra essas relações logo abaixo.

Todos os pacientes, em tese, entram pelo que a gente chama de triagem. Um primeiro contato, uma primeira recepção pelos profissionais indistintamente, profissionais tanto psicólogos quanto psiquiatras, que fazem essa primeira abordagem $e$ encaminham pros diferentes profissionais.

(...) os pacientes chegam, entram numa lista de espera de atendimento, aqueles que vêm com demanda espontânea ou encaminhados de outros médicos pro atendimento no serviço de saúde mental passam por uma triagem em grupo (...) Depois disso, os pacientes são encaminhados pra 'estudo de caso', que são individuais, né, e ai dura um tempo indeterminado, né, dura algumas sessões, às vezes mais sessões, onde você com o paciente, faz um acompanhamento com esse paciente, pra ver qual o melhor encaminhamento pra ele, né, qual o melhor tratamento pra esse paciente.

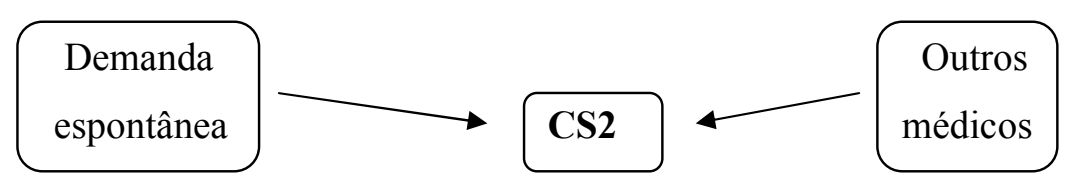




\section{Ambulatório:}

As características de chegada dos adolescentes no modelo de atenção ambulatorial, através da equipe de saúde mental do ambulatório de especialidades, se distinguem por dois aspectos, uma é a ausência de procura espontânea, identificada como procura dirigida à Unidade Básica e outra é a distinção de sua avaliação como mais aprofundada.

A gente recebe do Fórum, recebe do conselho tutelar e recebe direto de escolas, de abrigo às vezes direto, mas ai é diferente, não é uma coisa oficial, formal, mas essas pessoas que tem uma... intimidade já com a gente, sabe, já atendeu vários casos juntos, já resolveu coisas juntos, a pessoa liga e fala "tô com um problema" e você sabe que ela tá com um problema mesmo.

Então, para o ambulatório geralmente são... crianças $e$ adolescentes que já passaram por alguma... algum profissional da rede, né? É difícil vir procura espontânea para a gente, né? (...) Chega mais procura espontânea na Unidade Básica, e isso acontece, né? Do que no ambulatório, no ambulatório, geralmente, são casos foram, já passaram, alguém deu uma olhada, já viu alguma coisa e achou que seria interessante a gente fazer uma avaliação mais aprofundada de saúde mental, tanto de criança como de jovens.

As conexões, como mostra o diagrama a seguir, se ampliam, aparecendo a Coordenadoria de Educação e o Grupo Intersecretariado de Apoio à Inclusão (GIAI), o Fórum e o Conselho Tutelar como fontes encaminhadoras, diferente das Unidades Básicas. Além disso, a relação com essas outras instituições aparece de forma próxima e não-formal, onde as pessoas têm intimidade entre si e tomam os encaminhamentos como "verdadeiros", considerados a partir de experiências anteriores, aumentando a receptividade aos casos.

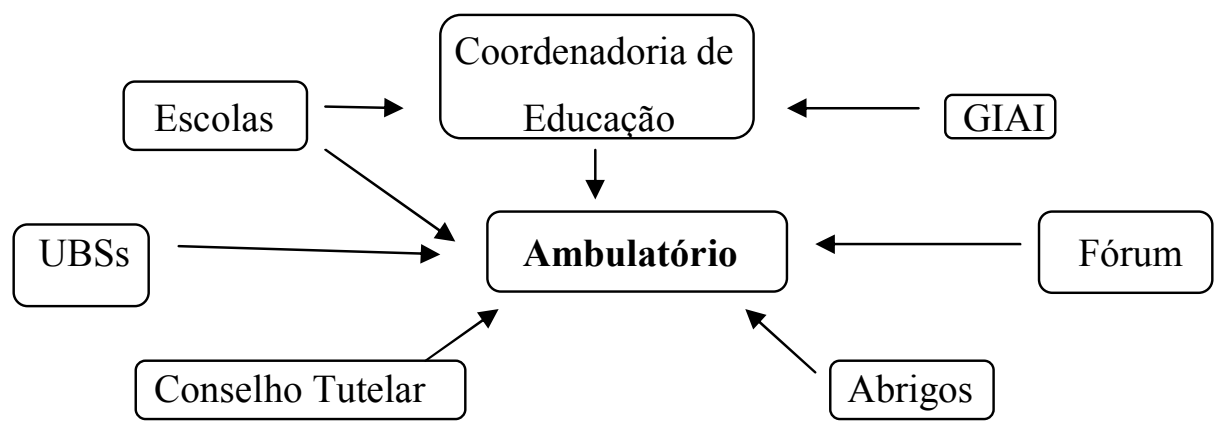




\section{CAPS:}

No dispositivo CAPS, os trabalhadores identificam o fluxo de encaminhamentos partindo preferencialmente das Unidades Básicas de saúde que se encarregariam de fazer uma seleção prévia dos casos e só lhes solicitariam quando houvesse a necessidade de uma avaliação maior e do pronto socorro através de um fluxo rápido e direto em que os casos chegariam "na hora", tendo em vista a característica de urgência.

Algumas falas que não foram expostas aqui, por serem demasiado longas na narrativa de uma história, apontam também para o contato com outras instituições de saúde mental não pertencentes à rede pública municipal e ainda clínicas-escolas de universidades privadas (justificando assim a presença desses serviços no diagrama a seguir). Ambas também são identificadas como fontes encaminhadoras, embora eventuais.

Tem muito adolescente de abrigo, ou pré-adolescente, do CRECA, ou de abrigo (...) ou ele acabou de sair do PS (...) ai eles encaminham para cá e tem que vim na hora, entendeu?

Eles vêm encaminhados por uma unidade básica ou, quando acontece uma situação de abrigamento alguém do abrigo liga, mas normalmente qual que é o tramite convencional: passar por uma unidade básica e dependendo da complexidade do caso é encaminhado para cá.

Olha, via de regras seria via unidade básica (...) os abrigos, os conselhos tutelares teriam que estar indo na UBS, procurando o serviço de saúde mental. Por exemplo, a escola encaminha, a escola encaminha bastante, vai para a unidade básica, na região a gente tem os núcleos em que estão as equipes de saúde mental (...) Então, chegando na unidade básica, eles vendo que precisa de uma equipe de saúde mental, eles referenciam ao núcleo, à equipe de saúde mental. Aí, passando pela equipe de lá (...) eles ligam para cá.

Olha, tem várias formas, até aqui fora tem um esqueminha (risos), não sei se você viu, tem um papelzinho pequenininho, que eu acho até que foi colocado aqui pra pros pacientes também entenderem um pouco. Os pacientes vêm de UBS, a rigor, pelo fluxo que deveria ser o ideal, os pacientes deveriam vir de uma... de UBS, quer dizer, os pacientes que já foram vistos por um pediatra, no caso, ou um clínico ou algum outro especialista que achou que tinha que ter um atendimento especifico, especializado, quer dizer, 
na verdade teria que passar pela UBS, pelo núcleo de saúde mental que tem nas regiões, quer dizer, aqui na região, e desse núcleo de saúde mental, não conseguindo resolver, deveria vir pro CAPS, né. Essa é uma forma. Outra seria dos pronto socorros, né, aqueles pacientes que estão em crise e que deveriam ter um atendimento rápido, mas não é bem assim, né, vem pacientes de tudo quanto é lugar.

O diagrama abaixo retrata o fluxo de encaminhamentos e inclui as instituições mencionadas acima:

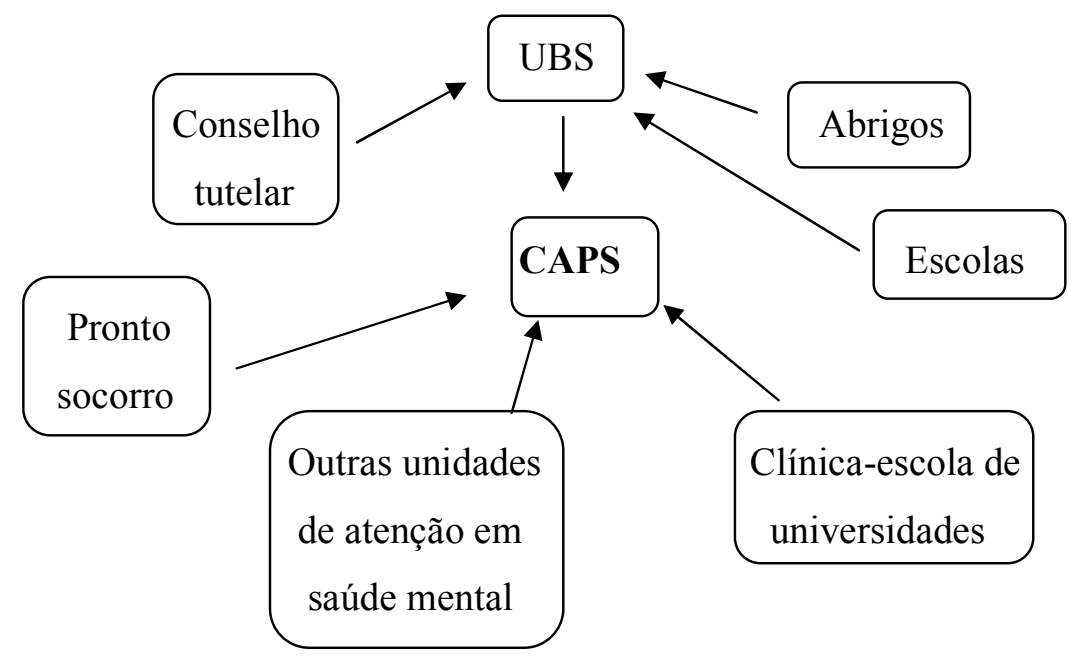

\section{Pronto socorro}

Por fim, o pronto socorro se caracteriza pela peculiaridade de receber indistintamente aqueles que chegam ao serviço, seja por encaminhamento de outras unidades (chamado de encaminhamento referenciado) ou de forma espontânea.

Alguns casos de... hoje, por exemplo, aqui eu já peguei crise de pânico, um menino de uma instituição que estava fazendo um passeio no parque Vila Lobos veio até aqui com uma funcionária da instituição, uma crise de pânico (...) Então, esse tipo de coisa a gente detecta aqui no PS todos os dias.

Então, ela se dá de igual modo, ou ela é espontânea, ou ela é referenciada. Referenciada é quando já vem de algum serviço e como nós somos o pronto socorro e a gente, como se fala? (...) a gente dá, nos somos referência pra 4 regiões (...) Então, os serviços que estão próximos, seja AMA, seja UBS, quando eles têm uma necessidade, ai eles acionam a gente e pedem uma avaliação. Existem também casos, por exemplo, nós temos aqui próximo da 
gente o CAPS infantil (...) eles acionam a gente pra uma vez ou outra, numa situação ou outra ficar com o adolescente na nossa observação.

Alguns casos, como retrata a primeira fala, chegam como fruto de uma crise imediata, outros, como aponta a segunda fala, chegam para uma avaliação ou para observação enviados por outras unidades da região para a qual o pronto socorro é referência, como AMAs, UBSs e o CAPS.

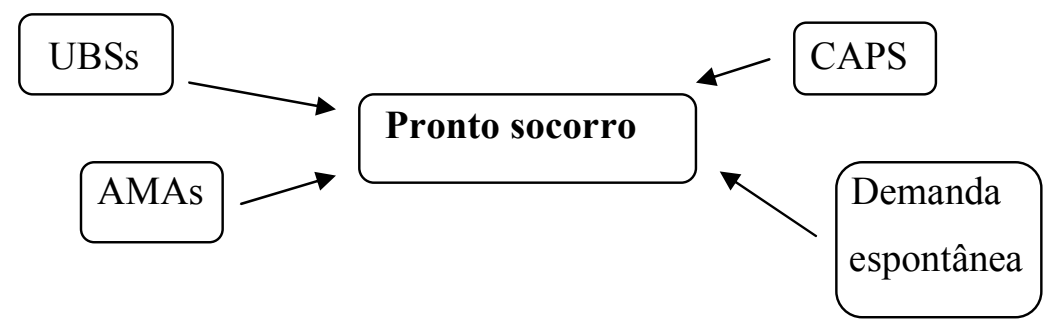

O quadro a seguir ilustra as fontes de encaminhamento para as unidades que fazem parte da pesquisa de acordo com as falas apresentadas acima:

\begin{tabular}{|c|c|c|c|c|c|c|c|c|c|c|}
\hline Fontes enc. Unidades & UBS1 & UBS2 & UBS3 & UBS4 & $\begin{array}{l}\text { UBS/ } \\
\text { PRÓ- } \\
\text { ADO }\end{array}$ & CSE1 & CSE2 & $\begin{array}{l}\text { AMB } \\
\text { DE } \\
\text { ESP }\end{array}$ & CAPS & PS \\
\hline ABRIGOS & & & & & ! & & & ! & - & \\
\hline AMA & & & & & & & & & & - \\
\hline CAPS & & & - & & & & & & & - \\
\hline CONSELHO TUTELAR & & & & & & & & - & - & \\
\hline COORD. EDUCAÇÃO & & & & & & & & - & & \\
\hline ENC. INTERNO & - & - & - & - & - & - & - & & & \\
\hline ESCOLA & - & - & - & - & - & & & - & - & \\
\hline ESPONTÂNEA & - & - & - & - & - & - & - & & & - \\
\hline FAMÍLIA & - & & & - & - & - & & & & \\
\hline FÓRUM & & & & & & & & - & & \\
\hline FUNDAÇÃO CASA & & & & & - & & & & & \\
\hline GAI & & & & & & & & - & & \\
\hline $\mathrm{HC}$ & & & - & & & & & & & \\
\hline OUTRAS INST. & & & - & & & & & & - & \\
\hline PRONTO SOCORRO & & & & & & & & & - & \\
\hline PSF & - & & & & & & & & & \\
\hline UBS & - & - & & & - & & & - & - & - \\
\hline
\end{tabular}


Tendo caracterizado a maneira "como eles chegam" nos serviços abordados, o passo seguinte, como anunciado no inicio deste eixo de análise, é descrever "como eles são recebidos", considerando nas falas algumas referências à forma como se organizam para escutar o motivo pelo qual o serviço é procurado, seja por uma prática formalizada pelo serviço, seja pela construção particular de cada trabalhador.

Iniciaremos novamente pelo modelo de atenção básica:

\section{UBS 1}

Nessa unidade, a recepção dos novos usuários se dá individualmente e as vagas são abertas todo dia 20 do mês, 8 vagas de cada psicólogo (totalizando 24 vagas). Este primeiro encontro é nomeado de "primeira consulta" e é oferecido individualmente para todas as idades. Depois de algumas entrevistas os psicólogos avaliam a necessidade de cada pessoa e caso seja incluído no serviço de saúde mental as possibilidades se definem como psicoterapia individual ou de grupo (este ultimo por norma) ou são procuradas outras atividades conforme a necessidade.

(...) atualmente a gente marca um dia, dia 20 de cada mês, a gente coloca lá na recepção um livro com o horário disponível pra uma primeira consulta dos psicólogos - nós somos 3 psicólogos (...)Ai a gente faz essa primeira consulta, né, então depois faz uma avaliação psicológica e aí a gente vê se a gente tem possibilidade de dar continuidade ao atendimento aqui, quando o paciente necessita, ou, se não, a gente encaminha pra fora, pra uma unidade de referência.

Eles chegam... passam por algumas entrevistas, a gente vê o encaminhamento certo e eles são encaminhados para onde tiver que ir e no caso da psicologia, pra atendimento individual e grupo, né, o destino final é sempre grupo obrigatoriamente, isso é uma norma federal inclusive, né, e... a gente também procura atividades conforme o caso (...).

Há algum tempo atrás, a gente fazia grupos de... pra receber, pra acolher, né, e... ai vinham os adolescentes - cada um na sua faixa etária, né, as crianças, os adolescentes, os adultos - e em grupo a gente podia observar, né, se eles tinham perfil pra grupo, mais pro individual e era uma maneira de escolher. Hoje em dia não, no dia 20 abrem as vagas então são marcados direto (silêncio). 
Uma das falas aponta para uma mudança recente nessa organização da "primeira consulta", que anteriormente era feita em grupos separados pela faixa etária e que serviam para "receber" e "acolher" os novos casos, valendo-se da experiência de grupo para "observar" o perfil e então "escolher".

Podemos observar então duas percepções diferentes sobre o mesmo serviço, uma voltada a uma forma anterior, não mais usada, que passa pelos significantes acolher, observar e escolher e outra forma, a atual, que se caracteriza pelo nome de primeira consulta e tem por objetivo a avaliação.

\section{UBS 2:}

Nesse caso, ao procurar o serviço de saúde mental da unidade, a pessoa pode escolher entre a entrada via grupo ou através do agendamento de um horário individual. A diferença entre eles, do ponto de vista do serviço, é o tempo de espera, que, organizado dessa forma, torna-se parte da escolha daquele que procura: se quiser ser atendido mais rapidamente, a opção é o grupo.

Existem dois grupos que funcionam como porta de entrada, um de terapia comunitária, semanal, e outro de acompanhamento, com base na terapia comunitária, mas que se diferencia do primeiro por uma maior liberdade na técnica. Os dois estão abertos para a chegada dos que vêm com uma "demanda de saúde mental".

A exceção se dá com a procura para crianças, onde o atendimento é preferencialmente individual, os adolescentes são atendidos como os adultos, por agendamento individual ou através desses grupos.

Elas vêm pra fazer o agendamento no balcão, aí elas são informadas que elas têm a possibilidade de participa dos grupos ou agendar um horário individual. (...) Lógico que conseguir o agendamento individual demora um pouco mais do que passar pelos grupos. Criança a gente pede pra que faça o agendamento individual. Adolescente e adulto pode ser, se tiver interesse, pelo grupo. (...) é um grupo que a gente tem alguns pacientes em acompanhamento e serve também como porta de entrada, uma das portas de entrada da UBS, casos novos que vêm pro grupo e que 
através do relato nesse grupo e da conversa que a gente tem ao término do grupo, a gente avalia para que serviços da unidade a gente pode encaminhar a pessoa. (...) a gente tem também um grupo de terapia comunitária aqui, uma vez por semana, que também funciona como porta de entrada, tá. (...) ele atende qualquer pessoa que venha com demanda de saúde mental.

\section{UBS 3:}

Essa outra unidade se organiza para receber aqueles que chegam com "demanda de saúde mental" através de um grupo nomeado como grupo de escuta. Esse grupo é aberto e não tem um limite de participantes, assim como também não se diferencia com relação a procura de crianças (através dos pais), adolescentes ou adultos.

(...) a gente tem um "grupo de escuta" aqui (...) um grupo que acontece uma vez por semana, porque tinha muita demanda reprimida de saúde mental, então a gente montou esse grupo de escuta onde assim, não tem nem um número estipulado, se tiverem 20 pessoas naquela fila lá para serem escutadas é um ouvido que a gente tem (...) é um uma escuta mesmo, né, pras pessoas que estão com sofrimento, mas não... ao invés de ficar em casa esperando uma vaga, vem para esse grupo e nesse grupo a gente faz uma primeira triagem de ver, por exemplo, se a prioridade é a psiquiatria, se é psicologia, se é encaminhamento para outra instituição, entendeu?

Como é que esses adolescentes chegaram no serviço? Foi pelo grupo de escuta (...) Então, as pessoas, elas primeiro passam por esse grupo de acolhimento, de escuta, ai na hora a gente vê se é caso pra individual, grupal, né... e já encaminhamos dali mesmo. Eu gosto de deixar sempre uma primeira entrevista individual, além do grupo de escuta, né, pra aprofundar melhor, tal... para ver se cabe em algum grupo, que grupo que caberia ou se é individual mesmo, né?!

É colocado que todos que estão aqui têm o seu problema, é só uma primeira escuta, não vamos discutir nada, é só pra ver se, realmente, nós temos como atender a demanda de vocês. E o adolescente se coloca, o adulto se coloca, os pais das crianças, tudo de uma forma bem sucinta, porque já é uma coisa muito dificil você ter que se abrir com uma pessoa estranha, ainda mais na frente de outras pessoas. 
As falas acima caracterizam esse grupo de escuta oras como uma primeira "triagem", "primeira escuta" ou como "acolhimento", sendo nomeado diferentemente por cada trabalhador. No entanto, sua função é a mesma para os três, identificar a prioridade e a possibilidade de atender a ela, seja através do serviço de psiquiatra ou de psicologia, de modo individual ou grupal. Também é verificada a necessidade de ser encaminhado para outro serviço.

Vale observar que essa organização se justifica, em uma das falas, como modo de atender os que chegam mais prontamente, para que não fiquem esperando em casa e não se configure uma fila de espera.

\section{UBS 4}

A unidade representada pelas falas abaixo se organizou recentemente no formato de "plantões de acolhimento para a saúde mental", onde cada membro da equipe se disponibiliza em determinado dia e horário para receber os que chegam e pedem por consulta de determinada abordagem, psiquiátrica ou psicológica, sem necessidade de um encaminhamento formal.

Olha, é mais ou menos... não tinha um procedimento, vinha aqui e queria marcar com um psicólogo. Deixa eu lembrar como é que era antes, porque agora a gente organizou. (...) era melhor fazer uns plantões para não ficar pesando só para um ou dois (...) um plantão de acolhimento para a saúde mental. Então quando os médicos encaminhavam, já diziam quais eram os dias que podia vir, os médicos daqui. Os de fora também, porque a gente informou, informou o CAPS infantil, o CAPS adulto, quais eram os dias.

(...) a pessoa chega e fala - acho que pra todas as coisas - "eu quero uma consulta psiquiátrica", ou "eu quero uma consulta com a psicóloga", não precisa de encaminhamento, não precisa o médico ter mandado, não precisa a escola ter pedido, nada.

Este procedimento, segundo a primeira fala, se organizou de forma a dividir a função de recepção entre todos, não pesando para alguns em especial. Uma vez delimitado esses dias e horários, informaram aos demais profissionais da unidade 
assim como de outras unidades para que os encaminhamentos fossem feitos para esse período de disponibilidade.

\section{UBS/PRO-ADOLESC}

O programa PRO-ADOLESC recebe os adolescentes que chegam de acordo com a procura específica. As consultas com a médica hebeatra são agendadas no balcão da unidade e os encaminhamentos de outros serviços da rede são recebidos por um membro da equipe que disponibiliza horários durante um dia da semana.

Então vai marcando, marca consulta lá em baixo e aí chegam, mas, como a gente tem um certo absenteísmo, a gente deixa em aberto os encaixes também (...) você faz um acolhimento, dentro da possibilidade, esse adolescente tem condições de ir pra um grupo (...) porque é impossivel você pensar que você pode botar todo mundo em terapia individual, né?!

(...) uma vez por semana, sempre de quarta-feira - porque eu conseguir fixar isso recentemente, para ficar mais fácil para rede saber e que pode mandar quarta-feira - eu tenho tanto o horário de manhã quanto horário a tarde (...) para receber até 4 casos, então pode agendar antes, mas sem... eu deixo 3 possibilidades... 3 vagas e um sempre em aberto para uma acolhida espontânea que alguém mandar.

No entanto, ambas dispõem de horários "de encaixe", ou de "acolhida

espontânea" para casos não agendados e que porventura apareçam em busca do serviço. O termo "acolhimento" é utilizado nas duas falas, no entanto a disponibilidade para a procura não prevista, ou não previamente agendada é nomeada distintamente sinalizando duas posições diferentes.

\section{CSE 1}

O Centro de Saúde 1 se caracteriza singularmente quanto à forma de recepção. Nesta unidade, o primeiro contato é sempre com a equipe de auxiliares de 
enfermagem que têm a função de entrevistar os que chegam para depois encaminhálos para o fluxo do serviço.

Essa entrevista de recepção é descrita da seguinte forma:

Essa recepção é feita em um ambiente fechado, em uma sala, a gente conversa com o paciente, dá a possibilidade que ele fale a respeito da vida dele, a gente tenta estabelecer um vínculo com ele, conter um pouco do sofrimento, da ansiedade que vem junto com o estar da saúde mental, com o chegar na saúde mental, e ai então passar para o fluxo de atendimento.

(...) porque para marcar uma consulta, a gente chama de..., porque primeiro o paciente chega, marca uma entrevista de recepção, que é com a enfermagem, que é a gente que vai fazer, nessa entrevista de recepção a gente pergunta tudo, né, conversa. Depois disso, o certo é a gente marcar uma consulta de caso novo, que é ou com o médico, o psiquiatra, ou com a terapeuta ocupacional, ou com o psicólogo, né?

Termos como estabelecimento de vínculo, contenção do sofrimento e da ansiedade apontam para uma intervenção não identificada até então nas demais unidades. Portanto, observamos duas características nesse tipo de recepção, a coleta de informações para um encaminhamento posterior de "primeira consulta" com a equipe técnica e um posicionamento interventivo que se justifica pelo entendimento da situação de chegada ao serviço de saúde mental como causador de ansiedade.

\section{CSE 2}

No Centro de Saúde 2 o procedimento de entrada é chamado de triagem que acontece individualmente ou em grupo por psicólogos e psiquiatras. Depois desse primeiro contato, ocorre o que eles chamam de "estudo de caso" que se caracterizam como atendimentos individuais com o propósito de "trabalhar a demanda ao serviço". Tal propósito se define como um maior contato com a pessoa para melhor compreensão da queixa e dos possíveis encaminhamentos.

Então, as pessoas entram é... por um espaço que a gente chama de triagem, que pode ser feito individualmente ou em grupo, dependendo do profissional que faz esse atendimento. Eu faço em 
grupo, já faço triagem em grupo há bastante tempo (...) e os adolescentes fazem parte desse trabalho de triagem sem nenhuma especificidade. Pode ser individual ou em grupo, basicamente é feita em grupo... às vezes eles vêm acompanhados dos pais, às vezes não vêm, vêm só os pais ou só a mãe, mais comumente, e algumas vezes vem ele sozinho e dai a gente não tem nenhuma, eu não faço pro grupo nenhuma pré determinação.

Todos os pacientes, em tese, entram pelo que a gente chama de triagem. Um primeiro contato, uma primeira recepção pelos profissionais indistintamente, profissionais tanto psicólogos quanto psiquiatras, que fazem essa primeira abordagem $e$ encaminham pros diferentes profissionais. $O$ adolescente, em especial, atualmente, eu acho que... vão acabar sendo atendidos, principalmente, por psicólogos, que a gente cost.. a gente chama de aprimorandos, que vão dar uma assistência psicoterápica individual. Raramente são medicados, tem um ou outro que está recebendo medicação e... não tendo outro o atendimento seria esse: psicoterápico e individual.

Depois disso, os pacientes são encaminhados pra 'estudo de caso', que são individuais (...) o 'estudo de caso' é... acho que é isso, é trabalhar essa demanda ao serviço, né, você, junto com o paciente, vai ouvir a demanda e tal, conversar um pouco pra ele, ver se a pessoa... ela... ela tá sensibilizada pra uma psicoterapia, se ela tá afim de fazer uma psicoterapia de grupo ou individual ou se a queixa dela é referente a outro tratamento, né, às vezes é mais do serviço de assistência social, por exemplo, às vezes da fono, né, acho que é você conhecer mais de perto o paciente, entrar mais em contato ali com ele, né, por algum tempo, pra pensar no tratamento dele, o que que... o que ele veio buscar e ficar mais

claro isso, sabe (...)

Observamos então uma recepção feita em dois momentos, um primeiro definido como triagem, depois do qual a pessoa pode vir a ser encaminhada para outros profissionais que farão um "estudo de caso" para determinar seu destino segundo suas necessidades e preferências.

\section{Ambulatório de especialidades:}

Como analisado anteriormente, o ambulatório de especialidades se distingue por receber os novos usuários preferencialmente por via de encaminhamento de outros serviços. Sendo assim, o que aparece nas falas dos trabalhadores que podem caracterizar o modo de recepção são fragmentos de primeiras intervenções: 
(...) às vezes é uma atuação na escola primeiro, a gente vai conversar com a professora, vê o que está acontecendo lá, para depois vir ver se é a caso para fazer contato para ser atendido (...)

(...) o que a gente estabeleceu como fluxo e que a gente pede pra fazer assim, mas nem sempre acontece, é de que antes de encaminhar o caso simplesmente por papel, converse com a gente sobre a criança e o jovem que tá encaminhando, e... ai a partir disso a gente: "ah, acho que é melhor passar por uma triagem", ai qualquer membro da equipe faz esse primeiro contato, pode ser uma psicóloga, pode ser psiquiatra, pode ser um terapeuta ocupacional, a gente recebe faz uma avaliação aí volta a discutir transferência.

A partir dessas falas, podemos pensar que o primeiro contato é mesmo com a instituição que encaminha, configurando uma pré-seleção do que será assumido como caso a ser atendido na unidade.

A primeira fala aponta para o um aprofundamento da queixa junto à instituição escolar, antes de definir se o caso será atendido ou não. A segunda fala da expectativa de que o caso encaminhado seja apresentado por aquele que encaminha para que, a partir dessa apresentação possa se propor um tipo de primeiro contato com a criança ou adolescente, que pode ser uma triagem com a finalidade de avaliação e possível encaminhamento.

\section{CAPS}

O CAPS, assim como o ambulatório, tem como via de acesso preferencial o encaminhamento externo, no entanto, como descrito pelos sujeitos abaixo, se organizam de forma a receber os que chegam via encaminhamento, com horário agendado, e também os não-agendados, considerando então a possibilidade de uma procura espontânea (o que não aparece no item anterior, sobre as possibilidades de acesso).

Então, é assim, independente da idade, ta? Tem o acolhimento que é diário e sempre tem alguém responsável; eu não estou no acolhimento, na grade, mas isso vai mudando entendeu? Então, por exemplo, de manhã tem uma grade, então é assim, se a pessoa chega, chega um pai e um filho que está com problema qualquer, 
de qualquer idade até 18 anos, né? Às vezes ele ate pode estar com um encaminhamento, mas ele não ligou, ele veio e ninguém conversou com a gente de outra unidade (...)

(...) aqui no CAPS, então passa pela avaliação, que é essa avaliação multidisciplinar, é composta por quatro profissionais: a médica, uma psicóloga, uma fono e eu, que sou enfermeira. Esses casos, eles permanecem na avaliação durante um mês. Então por quatro segundas-feiras, esses casos vão estar retornando e nós avaliando cada segunda-feira. (...) avaliação, como eu te disse, ela é agendada, né, data e horário. Então geralmente um profissional de uma UBS, né, Unidade Básica de Saúde, que nos liga, pode ser qualquer profissional: psicólogo, pediatra, fono, TO, então nos liga, pedindo um horário para estar fazendo uma avaliação nessa criança e, geralmente, eles já nos encaminham já um relatório.

Então, também através dessas avaliações de segunda-feira ou então são pacientes que passaram no pronto-socorro e, às vezes por tentativa de suicídio, então aí eles vêm pra cá encaminhados e começam a ser atendidos no intensivo.

(...) hoje a gente estaria acho que seriam mais ou menos duas portas de entrada que eu posso te dizer, que é assim, uma é a avaliação interdisciplinar, que a gente chama, que acontece todo mês, no começo do mês com casos que são agendados. Esses são esses pacientes que geralmente não são aqueles que estão em crise, não estão em situação de risco maior, são pacientes que estão passando em algum serviço e alguém acha que "olha, esse paciente precisa de uma avaliação mais especifica" (...) e a outra entrada é aquela que eu tava falando de casos mais agudos ou críticos que aí não esperam essa avaliação e entram pelo que a gente chama de atividade terapêtica, que ai são horários que a gente tem toda a semana, que são abertos, são profissionais já definidos que estão pra receber esses pacientes, ai a qualquer momento que for necessário.

Como conclui a ultima fala, o CAPS teria hoje duas portas de entrada, uma agendada previamente, nomeada como avaliação interdisciplinar e processada em quatro encontros semanais depois das quais toma-se uma decisão a respeito do caso, e a outra possibilidade seria destinada a casos mais agudos ou em crise que impossibilitam a espera para um agendamento de avaliação do primeiro tipo. Esses casos são recebidos através de uma atividade diária, chamada atividade terapêutica, que combina avaliação com uma intervenção imediata. 


\section{Pronto socorro}

O pronto socorro se distingue, em tese, dos demais serviços por receber situações de crise, de urgência. A forma de receber não se diferencia de outras modalidades de pronto atendimento, existe um profissional médico de plantão que atende os usuários por ordem de chegada.

A maior parte dessas informações não consta nas entrevistas e é fruto de observação, uma vez que as entrevistas foram realizadas no momento de "calmaria" dos atendimentos psiquiátricos na unidade.

Os usuários chegam, passam pelo balcão de recepção do pronto socorro, preenchem uma ficha e são encaminhados à sala do psiquiatra cujo caminho é identificado por faixas coloridas no chão.

Durante o tempo de permanência na unidade, pude perceber que a maioria das pessoas chega acompanhada, seja por familiares, seja por representantes de instituições ou do resgate.

Todos aguardam sua vez no saguão que dispõe de uma pequena sala de espera para a consulta com o médico psiquiatra.

Um fragmento de uma entrevista indica o percurso na unidade:

Eu fiz a modificação na medicação (...). E um encaminhamento para algum serviço da região, que é a orientação que a gente tem.

O psiquiatra medica (ou modifica a medicação já utilizada) e logo encaminha, seja para outros serviços da região, para uma curta permanência na enfermaria de observação ou para instituições de internação mais prolongada, o que depende da disponibilidade de vagas que são requeridas pelo pronto socorro. 


\section{Os Critérios Utilizados para a Inclusão de Adolescentes no Serviço}

Depois de investigarmos os meios pelos quais chegam os adolescentes e as formas de recepção empregadas pelas unidades, nos cabe perguntar quais os critérios utilizados para sua inclusão no programa ou não, pergunta que estrutura o trabalho e que para ser respondida necessita de uma ampla compreensão que tentamos alcançar através do conjunto dos eixos temáticos do processo de análise.

Ao falarem sobre os critérios de inclusão, alguns aspectos são colocados em evidência, como a urgência de algumas situações, como as tentativas de suicídio, ou questões que mobilizam as equipes ao ponto de permanecerem com o caso no serviço.

E eu sugiro, vou sugerir, que a gente deixe um horário para esses casos [casos de urgência], porque você nunca sabe quando vai acontecer uma urgência, obviamente, né? Mas eu acho que a gente tem que pensar de uma maneira de ter um espaço para esses casos. Pessoas que chegam dizendo que querem se matar. (psicóloga, sujeito 5)

Eu acho que tem a questão da gravidade. Por exemplo, os casos de abrigo que vem pra cá, são aqueles que já quebraram o abrigo, sabe? E não é... muitas vezes não é questão do adolescente, é a questão do funcionamento do abrigo. Então, tudo isso, assim... é visitado o abrigo ou a equipe vem aqui, vai lá. Então eu acho que quando é uma situação muito crítica, por exemplo, uma tentativa de suicídio, ou mesmo que seja só verbal, né, de falar, falar... a principio fica aqui (fono, sujeito 7)

(...) este é um caso que eu achei que estava grave, que chega com tentativa de suicídio, saiu do pronto socorro e às vezes ficou lá em internação, em observação, precisa de um atendimento mais intensivo, a gente já tem como estar encaminhando pra tarde, entendeu?! Então ela estava mal, angustiadíssima, chorando, falando em desistir da vida, em depressão, em tentativa de suicídio... aí eu combinei que ela ficaria à tarde. (assistente social, sujeito 11)

(...) porque você sabe, às vezes, quem trabalha nessa área, tem alguns casos que mobilizam mais a equipe, seja porque tem uma problemática diferenciada, sei lá, mas tem alguns casos que todo 
mundo sabe, né? Então para esses casos eu lembro, por exemplo, de um que o pessoal do PASA [Programa de saúde do Adulto] estava com muita dificuldade e a psicóloga aqui atendeu, né? Na recepção aqui, a gente ficou achando que a gente podia dar, que a gente podia fazer alguma coisa, porque o caso já estava tão mexido por aqui e tão vinculado, que a gente achou melhor ficar, né, com essa pessoa. (auxiliar de enfermagem, sujeito 12)

Outros casos são definidos como urgentes pelo incômodo nas instituições que freqüentam, causando o efeito de um remanejamento nos procedimentos habituais para serem atendidos prioritariamente, criando um "fluxo diferenciado".

(...) tem tanta coisa que merece atendimento, mas é o que não dá pra segurar mais (risos), acaba sendo critério o que tá incomodando demais, a escola tá com um grande problema, a pessoa não sabe mais o que fazer, ai eles trazem... (psiquiatra, sujeito 1)

quando a gente vê que o caso tá muito... se estiver muito muito grave, a gente já conversa com ele no dia, conversa com o médico que está aqui no dia, dependendo do caso já sai medicado e aí gente marca para daqui há 2 meses ou marca no meio assim. $O$ certo não seria, o certo seria marcar daqui há 2 meses mesmo para seguir todos os passos da saúde mental, então depende do caso, se for muito grave a gente conversa no dia, se for preciso; se for grave, mas se a gente acha que dá para esperar uns 2 ou 3 dias, ai a gente vai estourar a agenda do médico, a gente vai lá estoura mesmo na mão e coloca avaliação, e depois fala com ele. (auxiliar de enfermagem, sujeito 13)

no caso de uma gestante que está problemas na gestação, problemas na aceitação da gestação, está deprimida, está triste, não está conseguindo se adaptar a essa fase de vida, a gente tem um fluxo diferenciado, quer dizer, passa com a enfermagem, a enfermagem detecta que há necessidade de um acompanhamento, a gente tem um fila de espera da psicoterapia individual, mas no caso das gestantes a gente pula essa fila pela própria situação da gestação, e as adolescentes grávidas então entram dessa forma. (auxiliar de enfermagem, sujeito 12)

Então, pros adolescentes acho que não tem uma diferença do que pras crianças, assim, as situações são situações de crise, situações agudas, então são geralmente casos que vêm do pronto socorro, geralmente já tiveram atendimento, pra um surto psicótico geralmente já tiveram atendimento no pronto socorro, também tem casos que tem uma solução imediata, então, nem que não passe comigo eles entram pra um sistema que a gente chama de atendimento intensivo, onde eles já são acolhidos e passam a freqüentar, hã... situações de risco social, então às vezes não é exatamente um quadro psiquiátrico que é importante, mas a 
situação da família, a situação do adolescente dentro de uma especifica família, seja com violência, abuso, enfim, várias situações de família, né, o adolescente tá com risco de ir pra rua ou começou a ter fugas, coisas desse tipo. E, fora situações mais críticas assim, são os quadros psiquiátricos mais graves, então, autistas, né, aqui a gente tem recebido adolescentes aqui autistas, psicóticos mesmo, que já são... que são psicoses (...) e precisam de um atendimento, sei lá, mais intensivos, com outros profissionais. (...) Então acho que é muito da avaliação clínica, né?! (psiquiatra, sujeito 27, CAPS)

Outros critérios são justificados pelas características do serviço, como a presença de uma equipe multiprofissional com recursos para atendimentos mais complexos (no caso do CAPS e do ambulatório)

É um caso de uma gravidade que necessite de um atendimento bem mais intensivo, com uma equipe multiprofissional que esteja disponivel para estar acompanhando, olhando e seguindo. Como exemplo, eu posso citar: tentativas de suicídio em adolescente, em geral, é caso de CAPS; um adolescente ou uma criança com quadro de psicose; uma alteração de comportamento; agressividade; tentativa de fugir de casa... tem crianças $e$ adolescentes que partem para isso, arrumam a mochilinha e quer ir embora, "vou embora, vou embora", até sai de casa, passa uma noite fora de casa, depois acaba retornando, mas então, naquele momento aquele adolescente está precisando de um atendimento CAPS, porque ele está desnorteado, descontrolado, então têm várias situações. (enfermeira, sujeito 9)

Então, se for um.... uma criança que tenha uma (eu sempre me refiro à criança, mas o paciente, né?!) que tenha uma necessidade de um tratamento mais complexo, aí fica aqui, se não for aí volta pra unidade de referência, a Unidade Básica. Aí são os técnicos que decidem, né (...) Porque às vezes é um paciente que precisa de um tratamento só de fono, de psicologia, então dá pra ser tratado lá se tiver aquele profissional naquela Unidade Básica. Ai, é claro que as conversas são entre os técnicos que têm mais experiência, né?! (auxiliar de enfermagem, sujeito 21)

É um agrupamento de pessoas dispostas a atender casos um pouquinho mais graves. E eu vou vendo assim, olha, é porque vai precisar ir muito na escola, é porque a família tá muito desorganizada e precisa de mais gente, acaba sendo isso... o critério que a gente usa... pra gente receber... ou pra uma psicóloga mandar pra gente, entendeu? (psiquiatra, sujeito 1)

(...) eles [UBS] avaliando que é um caso mais grave, que vai precisar de um atendimento mais intensivo (...) se é um adolescente que tentou suicídio e chegou lá no resgate, ai eles 
ligam e a gente recebe em acolhimento (...).(assistente social, sujeito 11)

Em outros casos, pelo contrário, é a característica de abarcar casos avaliados como de menor gravidade, em uma perspectiva de prevenção e promoção de saúde, que norteiam a inclusão. Nestes, os casos de maior gravidade são referidos como casos para o CAPS.

(...) passou na porta, a gente viu é um caso mais tranqüilo, aí a gente faz todo o contato com a UBS pra estar encaminhando, né. (assistente social, sujeito 11)

(...) tem que fazer parte da nossa área de abrangência lógico (...)A gente atende, na verdade, casos leves e moderados, né?! Casos graves a gente encaminha pro CAPS infantil. Tem pouco, viu?! Não aparece muito. (psicóloga, sujeito 19)

São os casos que reagem bem a um acompanhamento ambulatorial, uma esquizofrenia... estável a gente também faz o acompanhamento, mas em momentos de crises, de surto, é o CAPS que faz. (psicóloga, sujeito 17)

Como o centro de saúde tende a atender pacientes menos graves, em geral é um critério que vai servir para diferenciar o adolescente grave daquele menos graves, e a gente vai tender reter o adolescente com um problema mais circunstancial ou menos complexo, no mesmo sentido do adulto. (psiquiatra, sujeito 24)

quando o paciente necessita (...) É, porque aqui a gente deveria atender, teoricamente, deveria atender os casos mais leves, com comprometimentos mais leves, né. No caso das crianças e adolescentes que têm um comprometimento maior, a gente encaminha pro CAPS (...) (psicóloga, sujeito 26)

aqui entra todo mundo, ta? Então entra aquele caso mais light, que eu acho que é um caso pra UBS, que é para ser trabalhado na $U B S$, de prevenção e promoção da saúde, né... e não os casos graves, mas chegam muitos casos graves. (assistente social, sujeito 18)

No caso de unidades especificas como o pronto socorro, o critério é tido sempre como de "não-inclusão", ou seja, é visto como um local de passagem que cumpre uma função determinada, relacionada à medicação e encaminhamento.

Eu encaminho todos que chegam aqui eu faço o encaminhamento, todos, sem exceção. Medico e faço o encaminhamento. (psiquiatra, sujeito 14) 
Algumas outras questões com relação à característica do serviço são levantadas como pontos de reflexão entre "o que deveria ser" e "o que acontece na prática”.

eu tenho uma preocupação de que quase tudo possa ficar (risos), não sei se tem a ver com a característica do serviço, serviço de porta, então é uma porta que até... mas a triagem é de algumas coisas que não caberiam. Como eu entendo que a porta deve pelo menos olhar pra tudo e tentar encaminhar tudo - é lógico que eu não dou conta de tudo, né?! (...) Mas eu acho que eu evito falar no termo triagem por conta disso. Assim, pelo menos nessa porta tudo entraria e eu tentaria encaminhar, né, todos os casos. (TO, sujeito 16)

Claro, com o quê que nós em princípio ficamos, né, só em princípio: casos estabilizados, né? Da ultima vez que se discutiu, que se escreveu alguma coisa escrita sobre isso, e ai vale para adultos, adolescentes, é que a gente também vai atender psicóticos, né?! (psicóloga, sujeito 20)

Embora a unidade básica de saúde devesse ter uma prioridade de trabalhar com a prevenção primaria, né, seria mais a parte da promoção da saúde, na realidade acaba-se trabalhando muito mais com o terciário, quando já se instalou a doença. (psicóloga, sujeito 5)

Quando os casos são encaminhados por outras instituições, por vezes causam algumas reações que se mostram relacionadas à decisão sobre a inclusão, algumas de aceitação do encaminhamento, outras de recusa.

quando a escola tem algum problema com alguma criança ou com um jovem dentro da escola, ou agressividade, ou mesmo transtorno mental, ou... geralmente são transtornos emocionais mais complicados e falta muito por conta disso.(TO, sujeito 2)

[os adolescentes da Fundação Casa] esses não tem chegado muito não, porque a nossa proposta seria não estar... estar segurando um pouco essa possibilidade de atendimento institucional mesmo, que estivesse com algum tipo de... que tivesse que vir acompanhado, que tivesse que vir armado, alguma coisa desse tipo. A gente tem conseguido ainda dar uma segurada, porque existem outras forma de atendimento também. (hebeatra, sujeito 15)

A questão da gravidade também é referida como motivo de inclusão ou encaminhamento relacionada à possibilidade do trabalhador, da equipe ou do serviço de dar conta do que julgam necessário para o cuidado. 
Na verdade não tem uma definição fechada. Os... os profissionais de saúde, né,... são geralmente, casos que eles estão achando, ou que eles não estão dando conta, são casos complexos de saúde mental, que eles não estão dando conta, que não vão dar conta em esquema de UBS, e também tem o lance de que, assim, não tem psiquiatra para infância e adolescente da região do Butantã, a não ser a J. que está no ambulatório, entendeu. (TO, sujeito2)

Então já teve casos que eles deram suporte por um tempo, né, e... "ó, mas tá precisando de uma intensidade que o programa saúde da família não vai dar conta" e ai ele encaminhou para a gente (...) (TO, sujeito 2)

porque eu sei qual é o meu limite, conversei com ela e a gente decidiu encaminhar essa garota para uma avaliação no CAPS infantil, pela gravidade do quadro. (...) porque se você não tem liberdade na equipe imagina você chegar e falar "meu, é um caso que acho que aqui, pra gente dar conta, precisa de uma coisa mais intensiva, de todo dia ou de toda semana, mais horas, né? (TO, sujeito 4)

A gente tenta absorver ao máximo, só quando é um caso que você considera que precisa de uma intervenção mais intensiva é que você não absorve. Ai não tem condições porque aqui é nível ambulatorial, então eu não posso pegar uma pessoa que eu sei que vai precisar de um atendimento intensivo ou vou ter que estar disponivel, sei lá, eu atendo hoje, mas amanhã, se ele não estiver bem eu vou ter que ter pelo menos uns 20 minutos para ouvi-lo, e eu não vou ter. Então, ai eu prefiro ou passar para CAPS, que é dificil, eu não gosto muito, ou para os programas específicos do HC. (psicóloga, sujeito 6)

ou "não, acho melhor... é um caso que vai demandar um tempo maior uma necessidade maior, um atendimento mais intensivo, melhor ele ficar aqui com a gente mesmo, e a gente assume o caso por inteiro". Mesmo porque, se tem que fazer alguma coisa na escola, se tem que falar com a família, a gente assume (TO, sujeito 2)

Existem ainda critérios que são construídos pela combinação do que é entendido como a necessidade do adolescente (ou daquele que busca o serviço de forma geral) e o que o serviço tem a oferecer. Nesses casos, a inclusão é feita tendo como elemento principal os recursos do serviço.

Essa decisão é com base no que a pessoa falou, no tipo de problema que ela tá trazendo, tá? Então a gente tem aqui... nós temos psiquiatra e psicólogos, a gente tem grupos de atividades de promoção à saúde. Então são atividades... é, tem grupo de relaxamento, tem grupo de Tai Chi Chuan, a gente tem terapeuta 
ocupacional que faz um trabalho corporal, super bacana. E... e ai a gente vê, de acordo com o que a pessoa tá falando, o que é necessário. (psicóloga, sujeito 3)

Eu acho que o que faz ficar ou ser encaminhado são os próprios limites do serviço, né? Por exemplo, a gente tem vários psiquiatras e poucos psicólogos, a gente tem fila de espera para psicoterapia, então é lógico que para a gente a coisa acaba se auto regulando, né, não tem muito se fica ou não; quer dizer, fica se for uma questão mais médica, uma questão psicológica a depender, que nem eu te falei, gestante, por exemplo, que eu estou me lembrando, né... O jeito do serviço já é uma própria forma de triar a demanda, $n e ́$, a demanda é diferente. (auxiliar de enfermagem, sujeito12)

É também com o que eu conto internamente, o que que eu tenho e o que eu tenho de rede, isso que também me define se eu fico com o caso ou não. (...) Mas a decisão se eu vou permanecer com o adolescente aqui ou não é o quanto eu tenho para oferecer aqui dentro do serviço (TO, sujeito 16)

(...) Então acho que para os adolescentes talvez a mesma coisa, não é o serviço, não tem um impedimento pra eles ficarem aqui, mas como ele está? A questão dele é uma questão que se resolve, que é contemplado por aquilo que nós oferecemos aqui? (psicóloga, sujeito 20)

Então, normalmente, quando é um paciente da nossa... da nossa região. (...) Então, a partir disso é que a gente forma essa decisão, né, se o que ele precisa a gente tem aqui pra oferecer ou não. (...) a gente não tem um trabalho especifico com a questão do uso de drogas, que é uma questão que às vezes traz o adolescente ao serviço, então se a gente avalia que esse é o foco do... da queixa e da necessidade de atendimento nesse momento também é onde a gente provavelmente vai encaminhar ai pra uma instituição que tenha isso mais... específico, com... possibilidade de cuidado (...) se é um paciente grave que precise ai de uma estrutura maior de atendimento, de um atendimento mais intensivo que a gente não possa dar, de um atendimento de várias vezes por semana, de um atendimento de TO, ai a gente também encaminha... (...) Ou se a gente não tiver vaga mesmo, ele precisar de uma psicoterapia... a gente também encaminha. (psicóloga, sujeito 22)

O centro de saúde pelo jeito que ele é organizado, ele é muito precário pra atender pacientes um pouco mais comprometidos. Agora, a característica, é evidente, tem paciente que, do ponto de vista de uma avaliação mais sutil, mais delicada, é muito mais grave do que um outro que, sei lá, tem seus surtos de agressividade. Mas na prática ver se de alguma forma o jeito como o centro de saúde está organizado permite ajudar. (psiquiatra, sujeito 24) 
(...) se a demanda condiz com o serviço, né, se ela veio buscar mesmo um serviço de saúde mental, né. Então, já aconteceu, por exemplo, de a gente, na própria triagem, fazer um encaminhamento direto, sem passar por 'estudo de caso' e tal, porque no momento, ali, a gente já identificou que não cabia no serviço de saúde mental, por exemplo, né. $O$ que que ele veio buscar no serviço e o que o serviço pode oferecer, né?! (psicóloga, sujeito 25)

Se a gente percebe que ele tem muito tempo ocioso além da escola, a gente encaminha pra serviços de acordo com o gosto deles ou habilidade, talento, percussão, enfim, pra outros estímulos. Se a questão é profissionalização a gente indica, a gente só não vai junto, mas a gente encaminha, indica, tudo. E... se precisar de socialização a gente encaminha para lugares onde eles possam ter essa resposta, ter essa possibilidade. (psicóloga, sujeito 28)

alguns são encaminhados pro CAPS, porque são... exigem uma... um atendimento mais... com maior freqüencia, são casos de psicóticos, que tentam o suicídio e outros são encaminhados pro grupo de outra pessoa, muitas vezes pessoa com insônia vai pro grupo de relaxamento, depende, né, ai é avaliado que tipo de atendimento que a pessoa possa se beneficiar. (psicóloga, sujeito 29)

Então o que a gente tem: atendimento médico para aqueles que precisam e são da nossa área de atendimento, e quando há necessidade de psicoterapia a gente encaminha. (...)(auxiliar de enfermagem, sujeito 12)

Mas a gente tendo a vaga, dificilmente a gente rejeita. (TO, sujeito 4)

Então, o adolescente, quando ele vem ao grupo e ele se coloca, então a gente vai avaliar qual é o caso. Esse adolescente, ele precisa... ele consegue se colocar no grupo? Qual é o problema que ele está trazendo? 'O que que eu preciso? Eu preciso de um acompanhamento psiquiátrico?' Se ele precisar de uma avaliação psiquiátrica, pelo menos, eu vou lhe fazer um encaminhamento pra uma outra unidade, porque os psiquiatras daqui não atendem crianças e adolescentes. (psicóloga, sujeito 3)

Também aparecem questões que apontam para a construção de critérios que se baseiam nos prejuízos percebidos na vida do adolescente e assim justificam sua inclusão em um serviço de saúde mental. Mesmo quando não são qualificados como graves ou urgentes, tais critérios denotam concepções de adoecimento na adolescência que necessitariam, do ponto de vista do trabalhador, do cuidado oferecido pelo serviço de saúde mental. 
um adolescente que tentou suicídio, ou que está com transtorno de ansiedade e não está conseguindo fazer as coisas (...) Teve época que a gente teve vários adolescente com questões assim, sabe, de... acho que foi ano passado ou retrasado, acho que no ano que eu entrei, questões, assim, de terem usado drogas, de estar meio perdidão na vida, não tem objetivo, sabe? Ai entra numa depressão, coisa assim. (fono, sujeito 7)

quando a unidade básica liga aqui e fala assim "olha, o caso está muito grave, a criança está muito agitada, ou a criança ou o adolescente, está tendo perdas importantes na vida, está deixando de ir à escola, está deixando de se comunicar com seus colegas, está deixando de fazer vínculos". (...) Crianças e adolescentes que chegam com casos graves, com perdas significativas aí na questão da autonomia. (TO, sujeito 8)

alguns casos que vêm, que a demanda está grave, que a situação familiar está grave, que a situação do adolescente está um pouco grave, e ai o que eles chamam, né, de grave, o problema é que ele não consegue ir na escola, está faltando, está vendo que a vida da criança tá complicada, ou do adolescentes - eu falo criança (risos), mas adolescente também, né?! - está complicada, está gerando algum conflito, tá deixando de ir na escola, a gente acaba tendo um - lógico que é questão da escola também - aí a gente acaba absorvendo aqui para ver ou pra avaliar, pra acompanhar. (assistente social, sujeito 11)

Eu acho que para mim, um caso muito grave é quando a pessoa está... porque qualquer doença mental prejudica a sua saúde, prejudica o seu contato social, mas para mim é quando já está demais, quando a pessoa já está pensando em não viver mais, não sai de casa, que já muito prejudicado essa parte, porque tem gente que vem, que está deprimido, tem alguma coisa, mas ainda consegue sair, veio procurar ajuda, tenta melhorar por si, pela força, mas tem gente que não, que você vê que aquela pessoa já está no limite, eu acho que é uma coisa mais de sensação, porque a gente conversando, não sei, tem gente que parece tão bem que você conversa e a pessoa está falando do problema como se estivesse ótima, você tem a sensação que tem alguma coisa estranha, alguma coisa que não está legal (auxiliar de enfermagem, sujeito 13)

Então muitos com dificuldade escolar, dificuldade de aprendizagem, dificuldade de entrosamento, crianças que ficam expostas a brincadeiras desagradáveis de outros colegas, sendo chamados de gay ou viadinho, sendo ou sem ser. A gente tem uma demanda grande. Brigas entre irmãos, algumas delas sérias, não é uma briguinha normal entre irmãos. Uso de drogas. Olha, diferentes patologias (...) Dificuldades de aprendizagem que são devido ao emocional é aqui também; alguma dislexia, alguma coisa, as fonos fazem um trabalho. (psicóloga, sujeito 17) 
então eu conto um pouquinho o que que a gente normalmente recebe, que a gente recebe adolescentes que vêm com problemas na escola, com alguma dificuldade ou algum problema em casa, às vezes, porque estão mais tristes assim, às vezes... eu tento traduzir um pouco qual é a demanda que a gente recebe. Às vezes tem algum problema alimentar, que a gente recebe adolescentes com a questão da bulimia, a gente já teve caso de anorexia. (TO, sujeito 16)

É importante ressaltar que muitos trabalhadores explicitaram dúvida sobre os critérios que utilizam ou sobre a lógica destes critérios diante das situações que recebem.

a coisa não é tão precisa, às vezes a gente fica muito na duvida da questão diagnóstica, até por questão de formação, tem pouca formação, agora até tem, mas é uma questão cara, a gente já está até bancando a supervisão e tudo fica muito pesado, e às vezes, a gente fica "será que é o motivo mesmo, será que não é? Ai, mas ele fez contato olho a olho, o que isso quer dizer? Aceitou o toque". (TO, sujeito 8)

Isso não quer dizer que também a gente não se atrapalhe na hora de fazer, assim... o que atrapalha é assim, é uma demanda tão grande, é uma... é um leque de coisas, de situações tão diversificadas que você acaba, às vezes, se complicando, tem que tomar cuidado ou, às vezes, tipo assim, não tem como você dar uma resposta na hora... não assim, não pro paciente, você fica com aquilo pendente... (assistente social, sujeito 11)

É um critério, quer dizer, eu não sei se a gente tem, se eu tenho tão claro qual, exatamente, o caso que pode ficar e qual que não pode ficar. (TO, sujeito 16)

(...) chegam muitas situações que a gente fica "o que fazer?". A gente não pode deixar de atender, mas ao mesmo tempo, a gente não tem muitas condições de estar atendendo e também, às vezes não é o caso de ficar, tá... Casos de violência, né, de uso de drogas, se bem não é tanto que chega de uso de drogas, mas de violência são bastante os casos. (assistente social, sujeito 18)

Mas enfim, às vezes eu... quer dizer, muitas vezes eu tenho dúvida, entendeu? Então não é o que ficou, tem vezes até que o espirito geral da coisa, o que é da competência do CAPS e o que é daqui, nós temos uma dificuldade com o CAPS, não sei se é este CAPS, mas tem coisas que a gente acha que é para CAPS, que chega lá [UBS] e eles falam que não, às vezes, não sou que achei, era a doutora ou vai, define e eles acham que não, você vai falar e eles acham que... acho que nem passa pela questão de que lá tem pouco profissional, psiquiatra, também psicólogo não tem tanto, né? E tem casos que, às vezes, a gente até segura dá para 
trabalhar, se formou um vínculo você segura. (psicóloga, sujeito 20)

E por fim, algumas vezes o critério é suprir a falta de outros serviços, tendo em vista que algumas regiões são desassistidas.

Olha, bastante casos de pessoas esquizofrênicas, que tem algum problema grave, assim, e se você mandar ela procurar na área dela não tem psiquiatra, a gente sabe que não tem, aí fica, ai fica aqui; porque não vai adiantar, né, a gente vai encaminhar para um lugar que a gente sabe que não tem como ela fazer tratamento, então ela fica. (auxiliar de enfermagem, sujeito 13)

\section{Caracterização do Trabalho em Equipe na Unidade e o Papel Atribuído a ela na Decisão sobre a Seleção da Clientela}

No processo de decisão sobre a inclusão de novos usuários (no nosso caso, de adolescentes), o trabalho em equipe pode aparecer como importante recurso para solucionar dúvidas sobre o diagnóstico e sobre o projeto terapêutico, propiciando a troca de informações e de opiniões entre os trabalhadores, cada um com sua especialidade, até que se chegue a uma conclusão sobre a inclusão no programa.

(...) a gente leva para a discussão (...). Então aí a gente discute os casos, é onde a equipe da supervisão, supervisão clinica $e$ institucional que a gente têm, que é quinzenal (...) é discutir questões institucionais aí, qualquer, passar os informes $e$ discussões de casos. Então é nesse periodo que a gente senta e "olha, chegou um caso assim e assim, o que é que a gente faz, qual a conduta, o que um acha, o que o outro acha, a gente está com uma dúvida aí, até com uma dúvida diagnóstica, vale a pena uma psicóloga estar vendo, vale a pena uma psiquiátrica estar vendo, um outro profissional estar olhando pro caso", para ajudar a definir (...). (TO, sujeito 8)

(...) todos os casos que são encaminhados pra gente, todo mundo da equipe faz, assim, geralmente um assum... recebe o caso e depois isso é discutido na equipe qual o projeto terapêtico para 
aquela criança ou aquele adolescente que está chegando. (TO, sujeito 2)

(...) no final nós nos reunimos para tirar uma conclusão. A psiquiatra dá a parte dela, né, a opinião, o diagnóstico, etc., e nós, os demais membros da equipe de avaliação, nós também damos a nossa opinião dizendo como foi o comportamento da criança, os dados observados, colhidos, e se essa criança vai ficar conosco, né? (...) e nós discutimos, entre nós, para poder chegar a uma conclusão (...). (enfermeira, sujeito 9)

É, a gente define no próprio grupo de escuta, né? Dependendo da demanda a gente vê juntas ali o que seria melhor (...) Então eu acho que a gente nunca toma uma decisão sozinha aqui, quando o caso vem para o grupo de escuta, por isso que é legal estar sempre em duas ou em três, porque a escuta nossa, né, cada uma com a sua especialidade ali, né, compõe... né, não é uma coisa "ah, eu tô com horário, ah, então eu atendo", não, a gente sabe, ali, como uma conhece bem o trabalho da outra sabe discernir, né? Aparentemente pode ser um caso de psico e que ali, na hora " $H$ ", a gente vê que tem muito mais a ver com TO, entendeu? (TO, sujeito 4)

Ai, por exemplo, esse caso, vamos supor, no acolhimento que a gente já vê claramente que é de CAPS, que a criança foi observada, às vezes nem passa por essa avaliação grandona, entendeu? Já se discute na equipe, já pensa em pôr em algum grupo para observar como essa criança é, vai conversar com essa mãe, entendeu? (Fono, sujeito 7)

Então, em qualquer situação de dúvida, de preocupação, né, a gente procura alguém da equipe [de enfermagem] para conversar a respeito, ver qual que é o melhor encaminhamento que está precisando. (...) quando a própria equipe não dá conta: vamos conversar com o médico? vamos conversar com a psicóloga? Então tem um partilhar constante do trabalho, né? (auxiliar de enfermagem, sujeito 12)

(...) quem atende o telefone leva o caso pra reunião de equipe técnica, que é toda sexta-feira de manhã, e é discutido o caso. As vezes eles... e ai discute o caso e determinam se eles vão vir de manhã, o horário que eles vão vir, né? (auxiliar de enfermagem, sujeito 21)

Em alguns casos, essa discussão acontece informalmente entre alguns trabalhadores, não necessariamente em equipe, o que é descrito como positivo entre aqueles que trabalham há mais tempo juntos e que com isso contam com uma colaboração mutua, mas também como aspecto negativo, tendo em vista que dificulta a comunicação e não favorece a troca constante. 
(...) a equipe multidisciplinar você tem na medida que os seus colegas te conhecem de tantos anos, ser antiga e vice e versa (risos), porque eles também são e existe uma colaboração mútua. Mas não existe assim... um trabalho formal, né, de que passa comigo ai passa com $X, Y, Z$... isso não existe. (...) É tudo na base da informalidade. Ou então, se você consegue na formalidade, eu preciso também de você... Enquanto profissional você já sabe que as outras pessoas te respeitam e você também respeita os outros. (...)É assim que funciona, porque se eu conheço o trabalho do meu colega, se ele está me pedindo para eu dar uma olhada, passando por cima de outros, é porque o negócio é realmente pra ser levado a sério. (psicóloga, sujeito 6)

(...) porque a gente fica, por exemplo, se reunindo numa passada de corredor pra discutir um caso, a gente não tem uma coisa formal para uma discussão de casos, sabe? Então eu sinto que atrapalha um pouco, sabe? Nós temos que, às vezes, a gente tem que aproveitar um intervalinho ali na cozinha, aqui no corredor, mas no mais, assim, eu acho o trabalho de equipe aqui fantástico. A equipe de saúde mental, né? (TO, sujeito 4)

É assim que esse processo acontece, vêm acontecendo. A gente não tem aqui uma reunião de saúde mental, entendeu? Existe uma equipe de saúde mental, composta de manhã por duas psicólogas, uma fono e uma psiquiátrica; à tarde tem a psiquiatra, duas psicólogas e uma TO, mas a manhã não conversa com à tarde e a tarde não conversa com a manhã. Nós não temos uma reunião em conjunto na mesma unidade, e nem temos uma reunião com o período da tarde, discute-se casos isoladamente, assim, eu discuto um caso com a TO, né? (psicóloga, sujeito 5)

Eu acho que isso é um problema quando você não tem ninguém com quem você possa dividir o seu serviço, né? Quando você fica no que a gente chama de EUquipe, né, sou só eu (...). (TO, sujeito 2)

Essa necessidade de troca pode ser percebida mesmo quando a decisão se mostra com caráter de urgência, 'quando não dá pra esperar' a reunião ou possíveis conversas informais, mas ainda assim a equipe é avisada sobre a decisão e participa do processo através de anotações e conversas 'a posteriori'.

(...) quando não dá pra esperar a avaliação inter, pra estar com toda a equipe no dia tal, no horário tal... a gente já fala, já deixa a equipe avisada; veio de manhã, por exemplo, aí começou com uma tarde, né, eu tô de quarta à tarde, então se veio de manhã e eu vi que é um caso grave e precisa ficar na unidade, a gente já manda vir à tarde, já deixa avisado a equipe, passa pra enfermagem que vai vir uma pessoa, a gente anota e tudo e já é recebida no dia mesmo (...). (assistente social, sujeito 11) 
Em outros casos, o trabalho em equipe é referido como estratégia para incluir aqueles que se mostram resistentes à indicação inicial.

Então o paciente que está muito solto, tem envolvimento com alguma situação de risco, está muito vulnerável, então a gente procura passar no maior número de profissionais. Ou então é um paciente que está muito arisco, não quer, "ai não imagina, psicólogo", "não sou louco", toda uma situação assim "não, não quero vir, não quero vir para o médico, não quero, não estou interessado" (...). Então, essa possibilidade de você fazer uma rede, que seria o que a gente chama de rede de proteção, então, de repente, assim, não está muito a fim de passar em terapia, mas você percebe que ela está meio ruim, a postura, ou reclama de uma dor nas costas, então vai começar a passar com a fisioterapeuta. a gente tem uma possibilidade de troca muito grande, então é muito fácil de você fazer um fluxo para ir para a fono, para ir para fisioterapeuta e ai tem a possibilidade de fazer a troca também. (hebeatra, sujeito 15)

Em outros de forma inversa, é pela força da opinião da equipe que algumas portas podem se fechar:

Então tem grandes demandas para infantil, tem também para adolescentes, mas a equipe que ta lá se sente mais à vontade para atender crianças do que adolescentes, né? Então tem uma certa resistência da equipe quanto a isso. Ao meu entender, eu eu já até falei, há uma fantasia na equipe (no restante da equipe, né? Não se aplica a mim) de que casos de adolescentes dão muito mais trabalho do que casos de crianças. Eu não acho que seja... corresponda realmente à realidade, pensando o trabalho que a gente faz é complexo tanto quanto, tem algumas nuances por conta da faixa etária, o território onde a criança ta, o território onde o adolescente circula ou vive, né, mas eu não acho que seja de fato mais complicado atender, em saúde mental, o adolescente do que a criança. (TO, sujeito 2)

Percebemos então que o modelo de formação de equipes para o trabalho na maior parte das vezes é referido como facilitador nas decisões sobre a seleção da clientela, onde seus membros trocam experiências e dividem a responsabilidade da decisão tomada. Entretanto, esse funcionamento não é unânime e em alguns casos as decisões são tomadas individualmente assim como a continuidade do processo terapêutico, principalmente quando o trabalho tem um caráter ambulatorial e cada trabalhador se responsabiliza por suas funções separadamente. 
Vale ressaltar também que as decisões tomadas em equipe muitas vezes podem definir o funcionamento do serviço caracterizando-o de acordo com suas preferências que juntas assumem peso de norma, o que em alguns casos pode limitar o serviço oferecido.

\section{Função das políticas que caracterizam o serviço na decisão sobre a inclusão}

Quando questionados a respeito da função das políticas que caracterizam ou definem o serviço no momento de decisão sobre a inclusão ou não do adolescente na unidade, alguns se remetem às normas que identificam para onde devem ser encaminhados os casos segundo a necessidade de intensidade de tratamento, estando em uma ponta o CAPS (para casos de maior gravidade) e na outra a UBS (para casos menos graves).

nós temos, assim, em mente, quais casos que devem ficar, quais não necessitariam ficar; porque existem as unidades de apoio, por exemplo, existe uma próximo a nós aqui (...) que tem três psicólogas... então estão para atender a população da região, então só não atenderiam se fosse um caso de maior gravidade, ele precisaria realmente ficar no CAPS. Então esses critérios que nós temos aqui na unidade, eles não nos norteiam; se é um caso para CAPS, não tem como não ficar, vai ficar conosco, mas se não for, então ele vai retornar para a UBS da região. (enfermeira, sujeito 9)

Algum documento? Especificamente para questão de saúde mental, é assim: o que existe de normatização são os transtornos mentais graves que são atendidos em CAPS (...) (TO, sujeito 2)

Agora, se o critério... se eu pensar na UBS, né, como porta de entrada, isso não me ajuda muito, porque eu, de alguma forma, acho que... quer dizer, ajuda na medida em que pelo menos o acolhimento ele é amplo, né? Eu pelo menos entendo que a nossa missão - não sei se nós damos conta - mas a nossa missão é pelo menos o acolhimento de toda demanda de adolescente, estou 
tentando ajuntar a UBS e o... Pensando que é um programa que está na rede básica, né, tem algumas coisas que me ajudam a pensar que eu tenho uma maior complexidade de alguns casos, seja pelo diagnóstico, né... às vezes não é só diagnostico, às vezes eu... é que quando não é só... Deixa eu pensar. O diagnóstico é uma grande coisa, sei lá (...) (TO, sujeito 16)

Critérios, qual é o caso? Também esse é um critério pra posto de saúde? Os critérios nem sempre são tão claros, a gente acha que é um caso muito grave, que é o CAPS que precisa atender, por exemplo, tentativa de suicidio. Muitas vezes o CAPS acha que não, você manda para eles e eles mandam de volta. Mas existem critérios e dentro da psicologia eles são subjetivos, né? (psicóloga, sujeito 17)

No entanto, alguns trabalhadores se referem a um "buraco" que surge nessa divisão, quando se tratam de casos que não se enquadram em nenhuma das definições quanto à gravidade mencionados anteriormente. Nesse aspecto, as questões do adolescente podem intensificar essa percepção de uma "falta de lugar" para o tratamento, tendo em vista que sua queixa muitas vezes é de uma "falta de lugar" indiscriminada e difícil de ser caracterizada de acordo com as classificações e divisões políticas e técnicas dos serviços de saúde.

Assim, não tem por diagnóstico, tem por... e nem por gravidade, assim... não é tão claro. O que tem, é assim, os casos que necessitam de maior intensidade, não é?, vai pra CAPS. Casos que precisam de menor intensidade vão pra Unidade Básica, que é o que tá escrito lá, que seria o trabalho de CAPS. A gente não é CAPS e não é Unidade Básica (risos), a gente fica no meio do caminho, então tem que ter um critério nosso, mas uma coisa que oriente não. (psiquiatra, sujeito 1)

Eu acho que sim. A verdade é que, às vezes, a gente fica meio perdida no que fazer, né? Eu atendo um caso de CAPS, especifico de CAPS... é grave, não é tão grave pra ficar em CAPS, mas não é também o perfil da UBS, então, às vezes, fica ai uma lacuna, um meio... né, fica sem um lugar especifico de atendimento. (...) Eu penso que hoje a UBS é porta, sempre foi, mas hoje muito mais, é uma porta de entrada pra tudo, né, e sem muitas condições, sem estrutura, né... então, e aí, como assim, não existe... essa é a porta de entrada, então aqui entra todo mundo, tá?! (assistente social, sujeito 18)

(...) a gente tem casos de gravidade... a saúde mental... o posto de saúde, a unidade básica de saúde, ela... está definido que ela atende casos leves e moderados, né, de problemáticas, de patologias... se a gente pensar nesse sentido. E ela trabalha com 
prevenção, mas ela deveria trabalhar, deveria trabalhar muito mais com prevenção do que estão trabalhando, mas como não está previsto que a gente seja ambulatório e a gente na prática está sendo um ambulatório, não tem... o CAPS está encaminhando todos os casos ambulatoriais para unidade básica, porque CAPS não é para ter caso ambulatorial, eles deveriam encaminhar para o ambulatório, mas não tem ambulatório, ai eles encaminham para unidade básica. Então a prevenção realmente está acontecendo muito pouco. (psicóloga, sujeito 19)

Os critérios... eles... os critérios são claros, mas na teoria. $\mathrm{Na}$ prática isso não acontece. A gente tem muita dificuldade de encaminhar, a chamada rede de referência e contra-referência na prática funciona muito mal, muito precariamente. Temos dificuldade de encaminhar tanto pro CAPS infantil como pro CAPS adulto e eu acho que ficou um buraco, né, na... como foi programado a rede de saúde mental, né. Quando eu entrei no serviço público, nós tínhamos a unidade básica de saúde, fazendo atendimento de prevenção, promoção, etc; o ambulatório de saúde mental, no qual eu trabalhei 10 anos e depois o serviço terciário, né, que seria o hospital psiquiátrico, né, que atualmente foi substituido pelos hospitais-dia, os CAPS, etc e tal. Então fizeram uma reforma psiquiátrica, né, pra acabar com a internação psiquiátrica e criaram os HD's, que são os hospitais-dia, e criaram os CAPS e criaram os Centros de Convivencia. Só que eles tiraram o ambulatório de saúde mental, então nós não temos esse meio, né, na rede, fica faltando, fica um buraco. Então nós temos a unidade básica como porta de entrada, que somos nós, nós somos a porta de entrada pro serviço de saúde mental público e temos os CAPS, os HD's, os Centros de Convivência, né, agora até Residência Terapêutica também estão abrindo. No meio tem um vazio, então a gente acaba fazendo o trabalho da unidade básica, a porta de entrada, e do ambulatório. A gente fica sobrecarregada e a gente trabalha e condições muito precárias. (psicóloga, sujeito 26)

Além dos aspectos de caracterização dos serviços, outras falas circunscrevem a questão do diagnóstico como critério que por sua complexidade não está sujeito às normas ou, na opinião expressa por alguns trabalhadores, não deveriam ser definidos através de normas, uma vez que enrijeceriam a escuta clínica e limitariam as primeiras intervenções.

Eu acho que é uma... eu acho que tem muita coisa diferente (risos), cada caso é um caso, né?! Cada caso com a sua facilidade e com a sua complicação, então eu acho que você tem que estar... não dá pra você fechar só assim "o que é um CAPS, o que que atende num CAPS" só, acho que tem que ser um pouco mais aberto isso, para você poder estar dando algumas respostas ou até podendo, num 
atendimento, fazer algumas intervenções, algumas orientações, algumas condutas que você tenha que tomar, né? (assistente social, sujeito 11)

É... mais ou menos, né, a portaria é uma coisa muito ampla, né, ela é bem ampla e irrestrita, né (risos), é... a gente até foi ver, eu tava vendo outro dia os CIDs, né, se tinha alguma separação por CID, por patologias, mas não tem e a gente até acha que não tem que ter mesmo, então na verdade eu fui ver e engloba todos os "Fs", né, hã... (...) acho que ajuda a nortear pra outras classificações aí que eles fazem, né, mas não acho que tenham critérios tão definidos assim, acho que não daria também, né, ficariam muito rígidas, acho que não dá pra decidir isso previamente. Você sabe que o CAPS seria pra atender pacientes de maior gravidade e mais intensi, que precisa de uma maior intensidade, né, ai dentro disso acho que você tem uma variedade de transtornos, né, de situações que eu acho que não dá pra delimitar dentro de uma portaria, né. Não me lembro, assim, especificamente. (psiquiatra, sujeito 27)

(...) a coisa não é tão precisa, às vezes a gente fica muito na duvida da questão diagnóstica, até por questão de formação, tem pouca formação, agora até tem, mas é uma questão cara, a gente já está até bancando a supervisão e tudo fica muito pesado, e às vezes, a gente fica "será que é o motivo mesmo, será que não é? Ai, mas ele fez contato olho a olho, o que isso quer dizer? Aceitou o toque".

Um critério estipulado pela política de saúde do SUS que os trabalhadores julgam mais simples de seguir e que para alguns ajuda a definir quem será incluído no serviço é a organização das ações pela regionalização, restringindo o acesso aos moradores da região da unidade.

(...) os critérios do centro de saúde... eu acho que só o fato de ter uma coisa fechada, de ser área se você mora em tal rua você pode ser atendido aqui, se você mora em tal rua você não pode ser atendido aqui, é uma coisa mais fácil, né, porque você sabe que não é área, você manda pra outro lugar que seja a área da pessoa. (auxiliar de enfermagem, sujeito 13)

Olha, a gente tem uns critérios, alguns muito claros, por exemplo: você precisa morar na região, não adianta falar "olha, eu adorei o tratamento com a M.A., vou trazer minha sobrinha"; ou a sobrinha mora na região ou não, não pode trazer a sobrinha. (psicóloga, sujeito 17)

Essas diretrizes que definem o serviço... É, eu acho que ajudam... não sei se ajudam, mas pelo menos não atrapalham, entendeu? (risos) Não sei, é como eu te falei, a gente por ter bastante autonomia aqui, né... assim... a gente não tem, assim... é... talvez a 
gente atenda até além do que deveria, você entendeu? Além do que seria caso pra UBS. Se a gente for se basear pela diretriz, até... já começando pela questão da rede, da onde a pessoa mora, a gente atende muitos casos aqui que a pessoa vem de não sei onde, entendeu, a gente acaba pegando, a gente pede que seja atendido só com uma especialidade, sabe? Então se a gente fosse seguir corretamente, acho que muitos casos não seriam atendidos aqui por nós. (TO, sujeito 4)

Acho que sim, acho que sim, com certeza. Desde a questão da regionalização até a questão da possibilidade de acolhimento pra determinadas situações, né, que cabem ou não nos recursos, nas possibilidades de recursos terapêticos que a gente tem aqui. (psicóloga, sujeito 22)

A última fala aponta também para a normatização dos critérios de inclusão pela caracterização dos serviços, como citado anteriormente, e a penúltima acrescenta que, apesar de ser uma norma, os trabalhadores são dotados de certa autonomia para criar meios de incluir aqueles que em principio seriam remetidos a outra unidade.

O grau de autonomia dos trabalhadores para decidirem sobre o destino dos que procuram por tratamento também está ligado ao respaldo da equipe da qual fazem parte, seja pela postura de "bancar" as decisões de um de seus componentes, seja para sanarem as dúvidas que surgem no desenvolvimento dessa tarefa. Dessa forma as políticas figuram em segundo plano, sendo substituídas pela prática do trabalhador e do suporte que ele encontra em sua equipe de trabalho.

Tem essa normatização, que de certa forma, embasa o que a gente faz e fica lá, né? Agora, não sei se só isso é o que basta para deixar... que os adolescentes com casos de transtornos graves fiquem no ambulatório, acho que uma postura da equipe que banca, acho que isso é uma disponibilidade pessoal, para isso, acho que isso pesa, que eu acho que só o papel não faz o dia a dia da gente, eu acho que é importante porque dá um norte para você e tem algumas coisas que você faz que estão respaldadas no que está escrito. Eu acho importante ter a política pública estabelecida, mas só isso não basta (...). (TO, sujeito 2)

A gente não tem nenhum protocolo assim especifico, né, então a gente discute em grupo. (...) tem algumas situações que vêm que foi o que eu te falei, no caso da escola, vem com uma solicitação de psicólogo que vai simplesmente e passa pela... que passa simplesmente pela port... pela recepção ali, eles vão tentar mandar para um psicólogo, mas como a gente tem todo esse esquema de 
estar acolhendo o adolescente, um profissional da equipe, a gente tem conseguido, talvez, discutir... quando tem alguma dúvida, a gente faz a discussão. (hebeatra, sujeito 15)

Outros acham que as normas, quando seguidas, são de extrema importância na organização do serviço, sem as quais não haveria regra e a estrutura do trabalho estaria comprometida. No entanto, para que isso aconteça, as regras devem ser construídas em respeito aos que são submetidos a ela.

Quem vai ficar na UBS e quem vai para o CAPS ou para outros lugares? Olha, acho que ajuda, porque se não aqui viraria a casa da mãe Joana, né, acho que precisa ter regras. Rotina... uma rotina é estruturante (risos), uma regra seguida é estruturante também, né?! Claro que se essas regras forem elaboradas de acordo com o respeito ao profissional, ou ao usuário, ou à doença, enfim... As portarias, você fala, as leis, documentos norteadores, é isso? É, o documento norteador de uma unidade básica, eu acho que é importantíssimo, tem que ter, né?! (psicóloga, sujeito 5)

Por fim, alguns dizem não saber exatamente quais são as normas que regem o serviço, embora saibam que elas existem e que influenciam na decisão sobre a seleção da clientela.

Eu não sei se tem critério que define o serviço, porque esse aqui não é um serviço só de adolescente. (...) eu acho que... pelo menos comigo, não vou falar pelas colegas, eu acho que o que define se vai ficar ou não, não é... sim, pode definir num sentido assim, de um caso que... o que que é um caso pra CAPS, por exemplo, quando que eu vou... já recorri, em matéria de... - porque vem pouco, né - de crianças e adolescentes pro CAPS - mas não porque o... que define a unidade básica, mas sim como está definida a saúde mental, na saúde em geral. (psicóloga, sujeito 20)

acho que a maneira como funciona esse serviço, né, esse centro de saúde, ajuda a gente a definir isso, né, muitas vezes não é uma demanda pra um centro de saúde, é uma demanda pra um CAPS, é demanda pra uma outra instituição, né, que cumpra uma outra função que não a do centro de saúde, então sim... tem esses critérios. Agora, dizer que critérios são esses, assim... (risos)... é... você pensar que aqui é um atendimento primário, né, onde as pessoas chegam pela primeira vez e com, acho, demanda especifica e entender o que o centro de saúde é... oferece, né, um tratamento adequado, agora eu não saberia dizer quais critérios seriam esses, assim.(psicóloga, sujeito 25)

Os depoimentos apresentados sugerem que as políticas que caracterizam os serviços constituem o processo de decisão sobre a inclusão ou encaminhamento dos 
adolescentes. No entanto, embora elas sejam utilizadas como parâmetro do que o serviço deve oferecer, fatores como a complexidade da construção do diagnóstico, a ausência de outros serviços percebidos como necessários na rede e a importância do suporte da equipe são descritos como de igual importância, sem os quais as políticas são insuficientes.

\section{Caracterização do Acolhimento}

A estratégia do acolhimento, nas falas dos trabalhadores entrevistados, é caracterizada como um atendimento aos usuários que chegam sem um agendamento prévio ou encaminhamento formal de outra unidade ou instituição, que por vezes tem a função de porta de entrada mesmo que a pessoa que procura o serviço não venha a ser incluída na unidade.

$\mathrm{Na}$ maior parte dos serviços, o acolhimento é feito por escala de disponibilidade de algum trabalhador, seja técnico (profissionais de nível universitário) ou auxiliar (comumente auxiliares de enfermagem). Existe uma crítica ao agendamento do acolhimento, tendo em vista que uma de suas características definidoras é a recepção sem um agendamento prévio.

Para alguns, o momento do acolhimento tem por finalidade um levantamento sucinto de informações para um agendamento posterior ou até que seja disponibilizada uma vaga e ele possa entrar pelo fluxo habitual da unidade.

Então acolhimento na verdade é um serviço que tem que ter em qualquer unidade de saúde, pelo menos no município, não sei como é que funciona nas outras. Então a gente sabe que nas UBSs, eles até também vão revezando, eles tem equipes, né? Quer dizer, pessoas que "ah, segunda de manhã sou eu", "terça é fulano". Muitas vezes é a assistente social que faz, né? (Fono, sujeito7) 
Agora, o acolhimento é: o pai e a mãe de uma criança que nos procura sem um agendamento prévio, ou porque ele ouviu falar dessa unidade, ou ele soube através de uma escola, ou de um pai e uma mãe de uma outra criança ou adolescente e vêm por essas indicações, mas não tem um agendamento prévio, não tem um relatório, não tem um olhar de um outro profissional prévio, então nós vamos fazer o acolhimento no momento que ele chega, para não deixar o pai ou a mãe sair daqui sem nada, sem ser visto, então nós fazemos um acolhimento assim, um levantamento sucinto da historia do adolescente e já agendamos para que ele retorne no dia seguinte ou daqui uns dois ou três dias, quando houver uma vaga disponivel com um outro profissional, se for o caso, para colher com detalhes, com maior cuidado, com uma observação assim bem mais minuciosa, pra ver se o caso é realmente um caso pra CAPS. (enfermeira, sujeito 9)

Então, é... o acolhimento, eu acho que você pode fazer o acolhimento e necessariamente não é pra fazer uma... assim, você.... é um caso que você vá assumir como acompanhado lá, você pode fazer um acolhimento de uma situação, na unidade no geral. (TO, sujeito 2)

É também. É verdade. Não podia ter me esquecido. O acolhimento é feito qualquer dia da semana, de segunda a sexta, qualquer horário, a pessoa chega aqui e ai ela é atendida por um auxiliar de enfermagem ou por um técnico (...) Esse profissional não vai estar com esse horário na agenda aberto só para isso, de repente não chega e vocêfica com aquele horário em aberto, mas é alguém que pode se deslocar do atendimento, naquele momento, para olhar junto (...) e definir que enquadre, que manejo, o encaminhamento vai fazer dentro da unidade. É verdade, tem o acolhimento que é muito importante também e que é uma porta... porque a proposta do acolhimento é essa: uma porta de entrada. Então pode ser qualquer dia, qualquer horário de segunda à sexta, né? A gente só pede para chegar no máximo, se for no periodo da tarde, no máximo até às 16 horas mais ou menos, se não fica muito complicado, fica muito no final da tarde, ai por exemplo, você não consegue colher todos os dados, ai fica dificil, então a gente estabelece um horário, quatro, quatro e meia só para a gente... por uma questão de organização do serviço mesmo. (TO, sujeito 8)

O acolhimento é aberto, embora... a proposta do acolhimento eu acho que é ser aberta, embora algumas unidades básicas trabalhem com periodos de agendamento, horários fechados, né? Eu acho meio estranho. Mas aqui a gente tem pessoas referenciadas no período da manhã e no periodo da tarde para fazer esse acolhimento, então a gente procura não agendar, porque a gente acha que não é... "olha, eu vim aqui com horário marcado pra fazer um acolhimento"... a pessoa vem, tanto pode ser dessas unidades básicas que encaminham e não dá para esperar, como passou na porta ou aconteceu de vir e chegou 
direto, acontece também de chegar direto e não ter passado por nenhum serviço. (assistente social, sujeito 11)

Por vezes a estratégia de acolhimento é utilizada para verificar a necessidade do usuário, contrapor com os recursos do serviço e encaminhá-lo de acordo com essa relação de procura-oferta. Essa concepção de acolhimento, diferente da primeira, permite um tipo de agendamento, uma vez que existem dias e horários determinados para esse tipo de atendimento.

Uma das falas nos faz pensar que a recepção de alguém que chega à unidade sem um agendamento prévio, quando o trabalhador tem outros afazeres com hora marcada, pode causar certa ansiedade que teria por conseqüência um encaminhamento sintomático, ou seja, rápido e possivelmente prematuro.

O acolhimento é assim: (...) nós nos distribuímos e temos em 2 horários por dia; tem dia, evidentemente, que não tem acolhimento, tem algum horário... segunda de manha, por exemplo, não tem acolhimento (...) Então, cada uma de nós está em um desses periodos de acolhimento e a gente recebe naquele horário, tem um horário determinado, né? (...) a pessoa que vem procurar agendamento pra saúde mental, procura espontânea ou encaminhada por algum... por qualquer tipo de encaminhamento da região. E... esse acolhimento ele tem uma finalidade, assim, de você verificar se realmente é um caso que é caso de unidade básica, né, ou se é caso de alguma outra instância, né, de CAPS ou $U A D$, que é a unidade para álcool e drogas, né, ou então o centro de convivência, por exemplo, tem que verificar qual o melhor tipo de atendimento para aquele caso, né? (psicóloga, sujeito 19)

(...) hoje não era meu dia de acolhimento, a auxiliar de chefia mandou errado hoje, porque a colega que faz isso hoje está de férias, eu acabei na pressa, porque eu estava super aflita - porque tinha a pessoa que eu tinha que atender normal - pra encaminhar (risos), então... Mas porque normalmente é o que eu acabo fazendo, a gente acaba fazendo no acolhimento. Não é só burocratização, "vou marcar uma consulta com a psiquiatra", mas bom, o que essa pessoa pode precisar que o posto tem, que o serviço tem para ela ser melhor atendida, né?! (psicóloga, sujeito 20)

Por outro lado, outros trabalhadores definem o acolhimento como o procedimento que procura dar conta de situações "urgentes", ou que se preocupa em escutar a queixa e saber o motivo da procura sem que para isso o usuário tenha que marcar um horário. 
Vamos supor que a pessoa chegue desesperada e diga: "olha eu preciso agora falar com alguém, preciso começar a me tratar". Tendo alguém da saúde mental, entendeu, nunca a gente "ah, não espera até o grupo de escuta", entendeu? (...) a escuta a gente vai escutar a queixa principal, né, o primeiro histórico, o que motivou a pessoa a procurar o serviço, né? (TO, sujeito 4)

É uma coisa que tem que ter nas unidades. Você não pode... entendeu? Chega uma pessoa aqui, eu falo "sinto muito, é só com hora marcada, adeus!" Não pode fazer isso! Tem que ter o acolhimento. (Fono, sujeito 7)

Um sentido diferente dos anteriores aparece quando o acolhimento é descrito como uma prática contínua, utilizada não só no momento de chegada do usuário à unidade, mas também nas atividades (e entre elas) do trabalho cotidiano, sempre que existe uma solicitação do adolescente ou de sua família para alguma questão imprevista.

$O$ acolher, eu acho que você pode acolher em qualquer momento do atendimento, desde que entra até (...), porque o acolhimento, no meu entender, é você acolher o que está acontecendo no momento, no momento de triagem, no momento de atendimento regular (que já está estabelecido). (TO, sujeito 2)

(...) acolhimento, porque hoje em dia eu tenho escutado qual a diferença de recepção e acolhimento, acolhimento deveria ser sempre a possibilidade de qualquer um que se encontra no corredor, de várias pequenas intervenções de acolhida ao adolescente, que eu faço muito também, ao adolescente ou às famílias... (...) que é essa recepção do adolescente num espaço individualizado pra isso. (...) Eu tenho chamado de acolhimento este momento de atendimento mais individualizado, da primeira recepção do adolescente, mas se eu ampliar um pouco o meu olhar eu também faço diversos acolhimentos no meu dia a dia, eu sempre tenho a possibilidade de, entre uma atividade e outra, de resgatar um adolescente que não está mais aparecendo (risos), e de conversar com a mãe que vem me pedir alguma coisa (...). (TO, sujeito 16)

O acolhimento, no emaranhado dos discursos, ganha também uma característica virtual, ou melhor, é conceituada como uma prática que independe de um espaço físico ou de um momento específico, mas a ele é atribuído o caráter de bem receber, ou como diz um dos trabalhadores "fazer com que a pessoa se sinta bem" (logo abaixo): 
O acolhimento... não existe um espaço físico ou... porque algumas unidades têm "ah, o acolhimento seria só para estar conversando, ver o que está acontecendo, tudo...", o que está acontecendo, é assim, eles vêm, marcam uma consulta ou passam com a $P$., ou se é alguma coisa mais de urgência, ou algo pontual, ou então vê quem está na unidade que pode estar dando a cobertura, né? (...) então a gente tenta agilizar bem rapidamente o que for possivel para poder estar dando o suporte para esse adolescente. Agora, não existe um espaço físico que a gente fala, "ah, o acolhimento passa primeiro em tal local e vem para cá”. Não, ai é logo tentado agilizar, vai passando e dentro da necessidade a gente já faz um encaminhamento direto. (hebeatra, sujeito 15)

(...) eu acho que acolher... demanda, assim, mais emoção, mais envolvimento, né, do que simplesmente receber (...)Fazer com que a pessoa se sinta bem, se sinta compreendida, ouvida... é isso. (psicóloga, sujeito 29)

Outra possibilidade para o acolhimento é de ser uma prática terapêutica e muitas vezes resolutiva, ainda sob o ponto de vista dos trabalhadores, que propõem até mesmo outras denominações para essa intervenção que além de receber, trata. Esta perspectiva tem como base a concepção de que a escuta pode causar alivio, ou "catarse”, e que muitas vezes esse efeito basta para algumas pessoas que não voltam para iniciar um tratamento mais longo.

É, assim, a gente tenta chamar mais de "continência", tá?! A gente resolveu fazer essa diferenciação entre acolhimento e continência, porque acolhimento estava muito, muito batido e na prefeitura e em alguns serviços, acolhimento significa uma coisa horrivel, em que você, lógico, ouve e manda para lá, você distribui um pouco a demanda, né?! E pra a gente, o atendimento, o AE [atendimento de enfermagem] da recepção, ele já tem uma função, né, esta função de catarse, de alivio, de... alguns pacientes nem voltam mais, depois da conversa nem precisam mais de ajuda. Então tem alguma coisa que acontece ali, naquela relação, né, que surte um efeito. Então a gente achou que o acolhimento, da forma como ele estava sendo falado, não estava muito legal para o que a gente estava fazendo, né?! Então a gente sentou com a psicóloga aí numa época e resolvemos entender o que é continência, e achamos que continência tinha mais a ver com a gente (risos), então a gente prefere chamar hoje de continência, porque você acolhe e você cuida, vamos dizer assim. Você de alguma forma está respondendo um pouco também àquela demanda que o paciente está trazendo, né?! Acontece algo ali, não é só a distribuição. É também, mais não só (risos). (auxiliar de enfermagem, sujeito 12)

Tem pessoas que vêm aqui e você vê que você conversando uma ou duas vezes com essa pessoa, ela já vai levantar muita coisa, né, 
então não é porque é um acolhimento, que a gente chama de um acolhimento para você só dar uma pequena escuta, você vai dar só uma escuta. Se a pessoa está precisando, e você vê que é um momento propicio e vai ser benéfico para ela, você se estende um pouco mais e já faz um trabalho terapêutico com ela, porque tem casos que é isso, é uma conversa. Tem gente que vêm aqui precisando de uma boa conversa com alguém, (risos) entendeu? Não tá precisando de uma terapia, entende? Eu acho que uma boa conversa com alguém que ela confie, ajuda muito essa pessoa, né?! Então não precisa iniciar um processo terapêutico para você dizer que já está fazendo um trabalho terapêutico com ela, você pode aproveitar o acolhimento, você pode aproveitar o acolhimento para fazer isso. (psicóloga, sujeito 19)

Um aspecto importante, que não poderia faltar à discussão sobre a caracterização da estratégia de acolhimento é sua distinção do que costumeiramente vem sendo denominado como triagem. Muitas vezes o acolhimento é descrito em oposição à prática de triagem, e esta por sua vez também ganha matizes diferentes nas falas dos trabalhadores, oras sendo definida como uma prática que avalia, classifica e encaminha...

Então, triagem... - é, eu usei essa diferenciação de nome, né? (risos) - é que triagem, a impressão que eu tenho, e ai de novo é impressão, é que é muito usado, eu vou olhar a minha demanda e uma coisa fica e uma coisa não fica (...). (TO, sujeito 16)

(...) não é apenas uma triagem no sentido de verificar se é adaptado à unidade básica ou a CECCO, com uma visão restrita da gravidade (...). (psicóloga, sujeito 19)

...oras como um procedimento técnico de entrevista aprofundada com o objetivo de conhecer detalhadamente o usuário a partir de sua história de vida e dos sintomas que porventura o levaram ao serviço.

Então, eu acho que... tem uma triagem, a gente tem um formato mais especifico de que, pra mim, né, é um lugar onde eu tenho que ter mais ou menos claro que aquele caso é um caso que vai ficar, que eu vou sentar, porque no caso de ambulatório é um caso que a gente já discutiu previamente, então a gente já tem, mais ou menos, uma percepção de casos que ficam e de casos que não vão ficar para fazer acompanhamento com a gente ou não lá. Então eu já tenho... eu tiro história, sento com o pai, com a mãe, normalmente não é uma vez só, eu vejo a criança junto da família ou o jovem junto da família, ai depois separados, só a criança ou o jovem comigo. (TO, sujeito 2) 
A triagem é o horário que a pessoa pode agendar diretamente no balcão e ai a gente vai conversar individualmente, tá? Esse adolescente, ele pode vir sozinho, ele pode vir acompanhado pelos pais... a forma como ele chegar aqui ele vai ser recebido. E ai é uma triagem individual em que a gente faz uma anamnese e faz o encaminhamento necessário.

Na triagem, eu acho que é mais uma avaliação que você faz individual mais aprofundada do histórico de vida, se for uma criança então o desenvolvimento, pegar a família, saber, tentar entender essa dinâmica pra ver... porque às vezes a questão não está ali com a criança, é muito mais uma história da dinâmica

familiar e a que a criança tá refletindo ai em bode expiatório, né? (TO, sujeito 2)

Tendo em vista os discursos dos trabalhadores e os recortes escolhidos para análise, podemos identificar definições diferentes que culminam em práticas também singulares da estratégia de acolhimento.

De modo geral a prática do acolhimento está relacionada à possibilidade de receber ou não, de forma prevista ou não, aqueles que buscam o serviço de saúde mental.

\section{Reflexões sobre a Ausência de Adolescentes nos Serviços de Saúde}

Durante as entrevistas, um tema não previsto em nosso roteiro se mostrou como questão recorrente no discurso dos entrevistados, a ausência de adolescentes no serviço.

Para justificar essa ausência, algumas falas indicam a característica da região, que vem mudando há algum tempo e cuja demanda, segundo os trabalhadores, é em grande parte de idosos. No entanto, como nos lembra um dos sujeitos, os adolescentes estão na comunidade que possui escolas, parques, famílias, etc. Sendo assim, quais os motivos para que eles não cheguem aos serviços de saúde? 
Como dito anteriormente, alguns se referem a uma mudança populacional da região:

Então, quando é adolescente... acho que ultimamente eles não chegam muito. (...) então esse não é um serviço de adolescentes. Acho que também pode, eventualmente até podem pintar, a gente também não dificulta, eu acho, né?! (psicóloga, sujeito 20)

E existe essa percepção de que o adolescente vem pouco. Então a gente tem a questão da característica da área de abrangência das UBSs da região da lapa, temos poucos adolescentes, né, predomina muito mais o idoso e crianças, principalmente o idoso. (...) Então se você pegar qualquer UBS, as atividades que elas têm de promoção de saúde são voltadas pra população idosa. (psicóloga, sujeito 3)

Olha, eu não tenho dados mais seguros, agora, eu tenho a impressão que tanto criança quanto adolescente não tem vindo mais, ou tem vindo muito pouco... porque, sei lá, tem algumas explicações: mudou muito o perfil da clientela do centro de saúde, do bairro, e as crianças desapareceram, assim como os adolescentes. Já há um bom tempo. A grande demanda atual é de idosos. (psiquiatra, sujeito 24)

Outros entendem que os adolescentes não procuram serviços de saúde porque têm vergonha, pois o serviço está inserido na comunidade e eles correm o risco de encontrarem pessoas conhecidas o que os deixariam expostos ao preconceito que envolve principalmente os serviços de saúde mental:

(...) a exposição é sempre muito dolorida e, principalmente, porque aqui é uma região muito fechada. Eu acho que o adolescente (...), fechada porque todo mundo está no mesmo colégio, todo mundo se conhece, fácil de um comentar do outro, né, é tudo criança que você fala "olha não fala que está passando por psicóloga", porque se a pessoa souber ele sempre vai ser o bode expiatório da turma, e o adolescente é mais ou menos isso, então eles são justamente aqui, "ah ele está passando por psicóloga, não tem jeito", e o que acontece é que, entre eles próprios, eles começam "ah, passa na psicóloga", sabe? Não é chique conforme é para o adulto (risos) é... depõe contra. (psicóloga , sujeito 6)

Adolescentes, eu não sei se eles não chegam porque desconhecem o serviço, se porque têm vergonha dos amigos, se porque a família... porque às vezes a família tem mais preconceito do que os de fora, né. (...) o adolescente, é uma fase tão difícil do desenvolvimento, né, dessa passagem aí, a infância $e$ ai a adolescência bem no meio dessa história é um sofrimento, eu 
acredito que pra maioria é um sofrimento muito solitário. (TO, sujeito 4)

O número de adolescentes é pequeno e, eu acho que é uma característica própria do adolescente, não procurar a área de saúde. (...) porque a gente sabe que pro adolescente é dificil chegar na UBS, ele tem vergonha, muita gente conhece, eles chegam e eles encontram o vizinho, né? Para eles é dificil chegar até aqui (...). (psicóloga, sujeito 3)

Nesse caso, a escolha por não recorrer ao serviço de saúde mental é vista como um prejuízo para o adolescente, que acaba vivenciando seus conflitos de forma solitária para não serem alvos de possíveis estigmas que estão associados a esse tipo de serviço.

Por outro lado, outros entendem essa ausência com base em certo conceito sobre a adolescência, demarcada como um período de instabilidade acarretando em dificuldade para permanecer, aderir e/ou aprofundar seus questionamentos a respeito de si mesmos. Também entendem a adolescência como um período de contestação e fuga de discursos que os subjugam, o que possivelmente faria o discurso dos serviços em questão:

Mas a gente sente assim, que a aderência de... essa... o adolescente é muito instável, né? Então ele... é... a gente consegue, às vezes, fazer grupos pequenos, porque ele não adere, né, dificilmente ele adere a um trabalho (...). (assistente social, sujeito 18)

Adolescentes: essa é uma demanda que... sempre foi muito... engraçada, muito fugidia. O que acontece com o adolescente é que o adolescente é por demais refratário (...) o pessoal se inscreve, mas chega na hora não consegue vir. E quem vem é realmente... são os casos necessitam muito de auxilio, que tem coragem, que estão no momento, e isso é muito raro, você sabe. (...) o que acontecia era que, realmente, o grupo até começava, ficava firme, mas eles não conseguem ter aderência. É típico do adolescente mesmo, né, essa aderência é alguma coisa que traz como que um "ser subjugado a alguma coisa e eu não gosto" nessa idade. (psicóloga, sujeito 6)

A chegada dos adolescentes sempre foi mais rara, né, a gente sempre teve um número grande de crianças e grande de adultos e nessa UBS de idosos. Agora, com o incentivo do programa de adolescentes, tem chegado mais adolescente. Tem uma dificuldade que é a adesão deles, né, eles dificilmente dão continuidade ao trabalho que a gente começa com eles, né. (psicóloga, sujeito 26) 
(...) porque o adolescente tem uma questão da adesão, é uma questão, né? O quanto eles ficam, o quando eles permanecem. (TO, sujeito 16)

Considerando essas explicações construídas pelos trabalhadores, acrescentam-se também reflexões a respeito do que estariam em busca os adolescentes quando procuram serviços de saúde mental, uma vez que eles só chegam quando estão 'precisando', e não em busca de informações de caráter mais preventivo, como poderiam desejar os trabalhadores ou a família:

Ou ele está muito ruim, ou ele está muito bem (...) e o que a gente queria, justamente, eram as pessoas que fossem a uma abordagem preventiva e não só curativa, e a preventiva ficava só no nível informativo mesmo e... no prolongamento disso é que começava realmente a haver a evasão. (...) porque é precisando que eles encaram, não como um crescimento que pode ajudar. (psicóloga, sujeito 6)

Acho que essa questão de que os adolescentes procuram menos os serviços de saúde é fato, né, é uma fase onde eles estão aí preocupados, envolvidos, com uma série de outras questões e interesses e que só vêm ao médico mesmo quando tão doentes e precisam resolver aquilo ali e vão embora, então acho que isso também... Muitas vezes tem o desejo dos pais de que eles venham, mas eles não querem vir. (psicóloga, sujeito 22)

Desse ponto de vista, os adolescentes que procuram o serviço espontaneamente são minoria, pois e a maioria seria levada pelos pais (que também procuram o serviço para saberem lidar com seus filhos) ou encaminhada pela escola por queixas de comportamento ou de aprendizagem.

Olha, demanda espontânea é pouca, muito pouca, mas chega. Então sei lá, de 10 casos 1 é de demanda espontânea. A maior taxa encaminhada é ou trazida pelos pais que estão recomendados a virem procurar terapia ou eles não vão continuar na escola. Isso representa, vou falar em termos numéricos mesmo, representa... de 10 representa 6 e os outros, né, já tinha 1, restam 3, eles são encaminhados... porque os pais estão precisando de reforços pra cuidarem dos filhos... (psicóloga, sujeito 6)

(...) ainda é estranho pensar em adolescente, psicologia há tanto tempo aí, mas muitos vêm arrastados pela família (risos). (...) tem muitos que vêm meio bravos, porque "eu não sou louco, eu não tenho que vim em serviço para isso” (...). (TO, sujeito 16) 
Eu acho que vem pouco, uma quantidade pequena, e eu acho que sempre foi assim, viu, nessa unidade básica, sempre foi assim. Existe toda uma questão em relação ao adolescente, que assim, eu sei que é muito difícil realmente... porque assim, o adolescente não vem, eu acho que ele não vem muito no serviço de saúde, sozinho ele vem raramente, são muito raros aqueles que eu atendi que vieram sozinhos, que vieram pedir ajuda. (...) eu acho que o adolescente não gosta muito dessa idéia de vir em psicólogo, a mãe tem que trabalhar muito pra convencer ele a vir no psicólogo (risos), eu acho, essa é a minha avaliação da falta. (psicólogo, sujeito 19)

Isso porque, os adolescentes teriam acesso a informações (do ponto de vista preventivo, como mencionado anteriormente) por outros meios que não os serviços de saúde, tais como a internet, os meios de comunicação ou mesmo pela rede de amigos.

Eu acho que eles vêm menos, eu acho que tem é.... assim... o acesso que hoje em dia eles têm à informação e à outras fontes, né, de... recursos pra lidar com as questões inerente à essa fase da vida é muito maior, então o serviço de saúde fica mesmo em segundo plano. (psicóloga, sujeito 22)

Logo, surgem questionamentos sobre o que oferecer a eles (e como) para que o serviço seja reconhecido como possibilidade de ajuda, caso decidam fazer uso dele.

(...) eu acho que o importante é que quando eles precisarem eles voltem ao serviço pedir ajuda. Eu tenho alguns que fazem isso, ou eles ou suas mães depois buscam o serviço, por isso é que é importante a porta aberta. (TO, sujeito 16)

Tem uma série de coisa que seria importante pra você abrir dentro de um posto de saúde, um trabalho para adolescentes, mas eles não vêm, eles não vêm para cá, é muito difícil, a gente já tentou outras vezes nos postos de saúde... você tem que se implantar no local onde eles estão (...). Só fica sabendo que tem esse psicólogo aqui disponivel quem vem ao posto de saúde, né, a criança, o adulto, né, o pai do adolescente... mas eles trazem pouco o adolescente pra cá, eles não trazem muito não. (psicóloga, sujeito 19)

$\dot{E}$, hã em determinada época a gente avaliou que esse tempo de espera, em algumas situações, desmobilizava o adolescente pra vir buscar efetivamente o atendimento e que talvez uma vinculação mais imediata, o estabelecimento já de algum nível de transferência com um profissional da saúde mental no momento do encaminhamento pudesse garantir ai uma adesão maior ao 
atendimento, então o plantão tinha essa função (...). (psicóloga, sujeito 22)

Em meio a esse questionamento, alguns trabalhadores levantam a possibilidade de não possuírem recursos para oferecerem o que imaginam corresponder às necessidades dos adolescentes (na lógica de que eles não chegam porque os serviços não lhes oferece algo de que eles precisem) enquanto outros, inversamente, apontam a ausência de demanda como causa para a não mobilização de outros recursos (na lógica de que não havendo procura, não é necessário criar condições para oferecer).

Ai, de certa forma, a gente fica satisfeito de atender poucos adolescentes, é sinal que eles, os que precisam, conseguiram algum tipo de atendimento antes, ou estão sob atendimento, apesar de sermos carentes, né, nesse tipo de atendimento. Carentes, porque faltam, né, faltam profissionais pra atendimento especificamente de adolescentes, né. (psiquiatra, sujeito 23)

Talvez porque a gente não tenha nada específico, então a procura também não seja grande, né?! Eu acho que todo serviço, quer dizer, se você atende, se você tem um programa ou um esquema básico para atender diferenciadamente um certo grupo, você recebe mais pessoas... Se tivéssemos, provavelmente receberíamos, porque a gente tem uma área extensa, bastante grande, com várias escolas, tem CEU no meio, então lógico que a gente teria... a gente teria um encaminhamento maior, tanto das escolas quanto dos CEUs. (auxiliar de enfermagem, sujeito 12)

às vezes o adolescente ele não se adapta no grupo, né, a gente tem pouco... a gente tem poucos horários pra atendimento individual, né, então fica difícil. (psicóloga, sujeito 26)

Não tem um trabalho, porque também não teve uma solicitação $e$ nem que aparecessem casos, "ah, então está bom, vamos trabalhar com adolescentes grávidas", "nós vamos fazer isso ou aquilo em função dos adolescentes", não chegam as demandas e nem nada que muito faça a gente pensar. "Ah, então seria bom se a gente passasse a oferecer isso” (...). (psicóloga, sujeito 20)

De qualquer forma, o fato de não recorrerem aos serviços de saúde com a mesma freqüência das crianças (que são levadas por seus responsáveis), dos adultos ou idosos, não torna a população adolescente ausente das reflexões dos trabalhadores de saúde mental, disparando questionamentos sobre a lógica dos serviços com relação à garantia de acesso que respeite as características de cada segmento. 
Como sugerido pelas falas dos trabalhadores, a presença ou não de adolescentes nos serviços de saúde suscita indagações sobre as mudanças populacionais da região onde estão instalados, sobre as necessidades dessa população e de sua possível associação com o que comumente oferecem como possibilidade de atenção. 


\section{FORMAÇÃO E TRABALHO "EM REFORMA”}

Retomando o objetivo deste trabalho, nosso principal objeto de interesse se localiza na formulação e utilização de critérios por parte dos trabalhadores de saúde mental para a inclusão de adolescentes nos serviços em que trabalham. No entanto, no caminho traçado para chegarmos ao nosso objeto de estudo, esbarramos em questões que se mostram de grande relevância para esse momento de discussão.

Pertinentes ao nosso objetivo, apesar de não fazerem parte dele, estão as questões sobre a formação e os desafios encontrados pelo trabalhador de saúde mental no exercício de seu trabalho. Considerando o discurso dos trabalhadores entrevistados quanto à história profissional e trajetória na saúde mental ${ }^{7}$, a proposta desse item é discutir a formação para o trabalho e as questões mesmas do cotidiano deste como importantes elementos norteadores das decisões, julgamentos e escolhas frente às questões trazidas pelos usuários aos serviços.

Como apontado anteriormente, o trabalhador da saúde goza de grande autonomia e tem a possibilidade de tomar decisões e ações de acordo com seus próprios critérios (Merhy, 1997), tendo em vista que em muitos casos ele não tem a quem prestar contas, seja porque ocupa um lugar de saber, seja por suas condições de trabalho muitas vezes desvinculado de outros trabalhadores.

Podemos supor que tais critérios não sejam infundados e que os trabalhadores lancem mão deles por se caracterizarem muitas vezes como seus instrumentos de trabalho, em alguns casos o que utilizam com maior segurança.

No entanto, ao analisarmos a trajetória do conceito de loucura ao longo do tempo e de seu emprego na justificativa da criação de serviços que se propunham a tratá-la, percebemos a importância de observarmos atentamente a formação para o

\footnotetext{
${ }^{7}$ Analisado no primeiro eixo temático com início na p. 70.
} 
trabalho e a filosofia na qual se baseia, suas condições concretas e seu entorno, pois dessa forma podemos compor um cenário no qual o tratamento expressa um propósito, uma finalidade não isenta de uma função política e social além de aspectos intrínsecos ao próprio trabalhador que, como sujeito frente ao trabalho, dispõe de recursos próprios que delimitam também seu saber e sua prática.

Contudo, como assinala Onocko Campos (2005), a preocupação com o trabalhador nesse aspecto subjetivo só teve importância na década de $90 \mathrm{com}$ as mudanças propostas ao modelo assistencial, pois nesse contexto os trabalhadores assumiram papel protagonista tendo em vista que dependeria deles a eficácia da nova proposta.

Enquanto isso, como nos apontam os trabalhadores entrevistados, outras mudanças ocorreram sucessivamente transformando o trabalho em saúde em um contínuo campo de batalha política e ideológica frente ao qual deveriam se posicionar e responder no cotidiano, sempre afetado pelas mudanças governamentais.

Tomemos os acontecimentos dos últimos 20 anos como período que coaduna a reforma sanitária ${ }^{8}$ que culmina com a criação do SUS, a reforma psiquiátrica que acarreta na remodelação da rede se serviços a fim de substituir o hospital psiquiátrico e tudo isso sobre os trilhos de grandes mudanças políticas no país que saía do período de ditadura militar e lutava pela construção de um modelo de governo democrático.

Tais acontecimentos, todos ligados entre si, correspondem ao período de formação e trabalho da maioria de nossos entrevistados que contextualizam suas histórias pelo trajeto que fizeram no serviço público e na saúde mental tendo em maior ou menor grau uma leitura particular dessa conjunção de eventos.

Percebemos no relato dos trabalhadores que participaram desse estudo diferentes posicionamentos frente a esse momento de transformação política. Alguns deles se referem à busca pelo trabalho no serviço público pela identificação com alguns propósitos reformistas (que tomaremos aqui como propósitos que ainda estão

\footnotetext{
${ }^{8}$ Para maiores informações sobre o tema ver Berlinguer, G.; Teixeira, S.F.; Campos, G.W.: Reforma Sanitária - Brasil - Itália, Ed. Hucitec/CEBES, São Paulo, 1988.
} 
em processo de transformação), enquanto outros relatam escolhas norteadas por acontecimentos na vida pessoal, por 'falta de escolha', por curiosidade, por ter encontrado a possibilidade de trabalhar especificamente com um público de preferência ou por preferências de trabalho que acreditavam somente viáveis no ambiente da saúde pública, como o trabalho em equipe multiprofissional.

Considerando os motivos referidos à escolha pelo trabalho como parte importante do posicionamento frente a ele e retomando a contribuição de Onocko Campos (2005), muito referida na introdução quanto às questões do trabalhador no campo da saúde mental, é a qualidade do vínculo entre trabalhador e instituição e a crença no valor positivo do trabalho que garantem certa estruturação subjetiva do trabalhador e que possibilita suportar os possíveis mal-estares advindos de seu cotidiano.

Dessa forma, assinalamos o relato da história profissional e trajetória na saúde mental como circunscrição do vínculo construído com as instituições que compõem seu percurso profissional e o valor dado a esse percurso que culmina no trabalho atual.

Quando caracterizamos os trabalhadores entrevistados, observamos que embora a maioria estivesse a muitos anos na saúde mental e/ou na saúde pública, muitos tinham até 5 anos de trabalho na unidade atual e isso pode ser explicado por alguns remanejamentos de serviços relatados ora como imposições, ora como escolhas.

No caso dos remanejamentos descritos como impostos, um momento referido por muitos como representativo em suas histórias é a mudança de gestão de Luiza Erundina (1989-1993) para a gestão de Paulo Maluf (1993-1997) e a implantação do PAS (Plano de Atendimento à Saúde) como estruturação dos serviços de saúde no município.

A gestão de Luiza Erundina foi marcada, na fala dos entrevistados, pela implantação dos Hospitais-Dia (HDs) de saúde de mental, pela remoção zerada e por convênios com instituições de ensino (como a USP) para formação continuada dos 
trabalhadores. Não é raro encontrar expressões como "na época da Erundina" para contextualizar um momento histórico especifico.

A implantação dos Hospitais-Dia é narrada como uma conquista do processo da reforma psiquiátrica e nesse momento alguns trabalhadores se candidatam aos concursos públicos pela identificação com a nova proposta de trabalho.

As "remoções zeradas" citadas em algumas entrevistas dizem respeito a uma política que teve grande impacto sobre os técnicos no final da gestão Erundina que aconteceu em todos os equipamentos e permitiu o remanejamento de pessoal, trazendo mudanças importantes nos locais de trabalho dos técnicos. Essa definição da Secretaria Municipal de Saúde privilegiava a qualificação necessária para ocupar certos cargos, considerando as atribuições inerentes à formação do servidor; todas as vagas eram colocadas à escolha e tinham prioridade aqueles que tinham melhor classificação no concurso e maior tempo de trabalho na Prefeitura. (LOPES, 1999)

Uma crítica feita a essa política era a conseqüente desarticulação que ela causava nas equipes de regiões periféricas que já mantinham dificuldades constantes para manutenção de uma equipe especializada. No entanto, para os trabalhadores ela possibilitou a 'escolha' de vaga e de região e marca para eles uma gratificação por tempo de trabalho que lhes garantia a possibilidade de trabalharem em locais próximos a suas residências e da escola dos filhos ou ainda em locais que escolhiam pela preferência de trabalho (justificada pela modalidade de atenção).

Podemos dizer, quanto a esse aspecto, que a região escolhida para a pesquisa (zona oeste de São Paulo) é caracterizada por trabalhadores com muitos anos de trabalho na rede pública, o que se justifica ao pensarmos que durante esses remanejamentos eles puderam se transferir para essa região que por sua disposição geográfica central e pelos recursos que apresenta se mostra como privilegiada na cidade.

Vale observar também que alguns trabalhadores se referem a cursos de formação complementar na Faculdade de Saúde Pública da USP, principalmente na 
ocasião desse convênio entre a prefeitura de São Paulo e a Universidade de São Paulo.

Com o fim da gestão Erundina, no entanto, os trabalhadores fazem referência às mudanças impostas pela implantação do $\mathrm{PAS}^{9}$ por seu sucessor Paulo Maluf (prefeito de São Paulo de 1993 a 1997), programa que mobilizou ativamente os trabalhadores que, assumindo uma posição contrária à proposta, foram obrigados a deixarem a área da saúde e migrarem para outros campos, como o esporte ou trabalhos de promoção de saúde destinados à terceira idade.

Muitos trabalhadores, após essa experiência de remanejamento de funções com o PAS, mudaram seus destinos de trabalho quando puderam voltar para a área da saúde, seja pela descoberta de uma nova preferência (no caso do trabalho com promoção e prevenção), seja pela impossibilidade de retornarem à mesma unidade em que trabalhavam antes.

Dessa forma, percebemos que ainda outros fatores estão implicados no processo de trabalho, como a ideologia das gestões políticas no exercício de governo e as conseqüentes mudanças nas propostas de funcionamento dos serviços de saúde, que alteram as prioridades de atenção e as condições de trabalho, gerando diferentes posicionamentos por parte dos trabalhadores.

Em paralelo às questões políticas que permeiam o trabalho, as escolhas de formação complementar indicam percursos pessoais de grande importância para os trabalhadores que caracterizam seu trabalho e suas funções.

Sobre esse aspecto, vale retomar alguns pontos discutidos na introdução deste trabalho, especificamente no que se refere à formação. Lá argumentamos que o trabalhador de saúde que não conte com razoável formação técnica será submetido a mais um fator de sofrimento, a angústia de 'nada saber' e segundo Onocko Campos

\footnotetext{
${ }^{9}$ Ver Elias PE. PAS: um perfil neoliberal de gestão de sistema público de saúde. Estud. av. [online]. 1999, vol.13, n.35.
} 
(2005), "quando a insegurança técnica é grande, toda demanda é amplificada, não é possível discernir em relação a riscos e urgências".

Ainda fazendo referência à introdução, lembramos das recomendações feitas pela política de atenção à saúde mental da infância e adolescência sobre a disponibilidade de recursos humanos com formação específica nesta área, tendo em vista garantir mecanismos de capacitação e qualificação dos profissionais que atuam no campo da infância e da adolescência, assim como criar uma política nacional de formação que inclua treinamento e supervisão dos profissionais da rede básica envolvidos no atendimento ao usuário. (São Paulo [Estado], 2002)

O que percebemos através da fala dos entrevistados são remanejamentos (como apontado anteriormente) que pouco dependem da qualificação do trabalhador para exercer tal função. Como ilustram as falas recortadas nos eixos de análise, alguns deles se queixam de que não se sentem aptos a coordenarem grupos terapêuticos ou realizarem diagnósticos psicopatológicos uma vez que não possuem formação para essas funções, mas estão inseridos em modelos de atenção que pressupõem uma divisão igualitária de tarefas ou onde não existem trabalhadores mais qualificados para tal.

Um exemplo é a formação de recursos humanos do CAPS infano-juvenil (que como o nome diz é um serviço especializado para atender crianças e adolescentes) que foi configurado a partir do desmembramento de um ambulatório de saúde mental. Nesse caso, nem todos os trabalhadores tinham preferência e/ou formação especifica nas questões de saúde mental infanto-juvenil, mas alguns optaram por permanecer com a mesma equipe ou na mesma região.

A qualificação específica se torna um diferencial na medida em que argumentamos que são os meios técnicos que um trabalhador possui para a eficácia de sua prática e para a estruturação subjetiva frente ao seu trabalho que possibilitam que ele esteja aberto às inúmeras possibilidades de queixas que possam surgir como demanda ao serviço em que trabalha. 
Ainda nos relatos sobre escolhas de formação complementar, alguns trabalhadores apontam necessidades encontradas no trabalho cotidiano, preferências teóricas que gostariam de aprofundar e limites que pretendem superar (quando frente à demanda dos usuários), mas muitas falas assinalam dificuldades e impedimentos como falta de tempo (e nesse aspecto vale ressaltar que alguns possuem dois vínculos empregatícios), de dinheiro ou de apoio do governo.

É importante ressaltar, ainda que não nos aprofundemos, que alguns aspectos referentes às escolhas feitas pelos trabalhadores como a mudança de local de trabalho ou mesmo os entraves à formação continuada esbarram na questão de gênero. A maioria dos trabalhadores entrevistados é de mulheres (quase 90\%) e grande parte delas se referiu a condições pessoais e familiares no processo de escolha pelo trabalho, seja pela carga horária reduzida, seja pela possibilidade de trabalhar perto da escola dos filhos, o que não se fez presente nas escolhas dos trabalhadores homens. Quanto à formação continuada, algumas mulheres apontam a gravidez ou o aumento nas despesas da família com a chegada de filhos como elementos de dificuldade para continuarem com a formação através de especializações ou outros investimentos.

Vale dizer que a questão da formação para o trabalho em saúde mental vem tomando proporções maiores atualmente ${ }^{10}$ tendo em vista que a maioria das universidades, como declaro em meu relato pessoal na apresentação do tema da pesquisa, não acompanharam as mudanças políticas e conseqüentemente não oferecem aos seus alunos uma formação para o trabalho nesse campo especifico (da saúde mental no campo da saúde pública).

Sobre esse aspecto da discussão, Tatiana Ramminger (2006) em sua dissertação de mestrado pela Universidade Federal do Rio Grande do Sul questiona:

"a reforma psiquiátrica, entendida como proposta de desinstitucionalização, só é possivel com trabalhdores-militantes? Como a Reforma Psiquiátrica, como um regime de verdades,

\footnotetext{
${ }^{10}$ Refiro-me a apresentações e rodas de conversa no I Congresso de Saúde Mental realizado recentemente, em dezembro de 2008, inaugurando a Associação Brasileira de Saúde Mental (ABRASME)
} 
acolhe aqueles trabalhadores formados prioritariamente fora deste campo e que não têm a disponibilidade de implicação que a reforma exige? Qual é a flexibilidade das equipes de saúde mental para formação daqueles que não fazem parte da cepa militante?" (p. 93)

Alguns, como apontado em análise, ainda se valem da prática como elemento de formação contínua, afirmando que aprendem com o trabalho do dia-a-dia e no contato com os pacientes, mas afirmam a necessidade de supervisão que eles assinalam como recurso de investimento pessoal, uma vez que não contam com apoio financeiro do governo. As saídas encontradas são o custeio 'do próprio bolso', a supervisão oferecida voluntariamente por trabalhadores da rede aposentados ou aqueles que se disponibilizam (por também trabalharem na rede) a cobrar valores simbólicos.

O objetivo desse tema de discussão é apontar para a influência dos acontecimentos históricos no processo de trabalho, assim como as condições em que ele ocorre, seja pelo suporte material (recursos, estrutura do serviço, salário), mas principalmente pelo suporte à formação, tendo em vista as importantes mudanças que vem ocorrendo no âmbito político, social, ideológico e assistencial que só serão verdadeiramente viabilizados através do processo de trabalho.

\section{REFLEXÕES SOBRE A PRÁTICA DO ACOLHIMENTO}

Partindo das reflexões sobre a formação e o trabalho em saúde mental e do processo de mudança dos modelos de atenção, a intenção é abordar a estratégia de acolhimento como aspecto do trabalho que ilustra a dificuldade de transpor para o campo da prática os novos paradigmas da saúde mental.

Como considerado anteriormente, o acolhimento se define enquanto estratégia que visa facilitar o acesso dos usuários aos serviços de saúde e para isso se 
fundamenta na proposta de que as portas estejam sempre abertas para receber aqueles que buscam o serviço, sem com isso desconsiderar suas limitações.

Em tese, acolher significa 'atender prontamente' aqueles que procuram o serviço de acordo com os princípios de acesso universal, equidade e integralidade da atenção preconizados pelo SUS, ou seja, resumidamente é garantir o direito à saúde como responsabilidade do Estado na medida da necessidade de cada individuo ou grupo a partir de um ponto de vista integral e não segmentado.

Silveira (2003), em sua dissertação de mestrado sobre o cuidado em saúde mental sintetiza a idéia de acolhimento como um conceito operacional que possibilita transformações no campo da experiência de encontro entre usuário e profissional:

Na verdade, a utilização de conceitos operacionais como o
acolhimento visa produzir novos sentidos nas negociações
estabelecidas entre a população que chega à unidade de saúde
demandando algum tipo de assistência e os profissionais que ali
atuam, pois entendido como conceito operativo, o acolhimento
pode ser capaz de tangenciar e agenciar transformaçóes no campo
das experiências de encontro entre o usuário e o profissional da
atenção básica, criando outras formas de produzir saúde. (p. 50)

Contudo, analisando dois aspectos do trabalho referenciados nas entrevistas com os trabalhadores ${ }^{11}$, percebemos outras concepções sobre essa estratégia.

Quanto à forma como eles são recebidos, destacam-se procedimentos como a abertura de vagas mensalmente para primeira consulta individual com o objetivo de avaliar as necessidades; grupos abertos (de acompanhamento) ou agendamento individual para identificação de prioridades e a possibilidade de atender a elas; recepção semanal com a disponibilidade de horários específicos para tal; agendamento para avaliação interdisciplinar (para casos encaminhados) e grade de acolhimento para pessoas que chegam espontaneamente ou situações de crise que são encaminhados para uma atividade que se propõe a avaliar e intervir imediatamente e ainda entrevistas individuais sem a necessidade de agendamento prévio com o intuito

\footnotetext{
11 Os aspectos analisados são: o processo de entrada de adolescentes na unidade (pp.75-98) e a caracterização de acolhimento (pp. 117-122).
} 
de formação de vínculo e contenção do sofrimento, antes da primeira consulta com profissional técnico (graduado).

Outras práticas são denominadas como triagem, individual ou em grupo, para uma primeira escuta breve ou ainda a recepção de casos pré-avaliados por outros serviços que já encaminham diretamente para tratamento.

Considerando o discurso teórico anteriormente descrito e mais aprofundado na introdução do trabalho, a única prática encontrada como forma de receber os usuários que se aproxima do conceito de acolhimento (embora alguns assim o denominem) é realizada em um serviço especifico que tem uma equipe cuja função principal é a prática de entrevistas sem agendamento prévio que são realizadas antes do encaminhamento para consultas específicas.

Esses trabalhadores, segundo a descrição fornecida, estariam disponíveis para receber qualquer pessoa que chegue ao serviço em busca de atendimento e nomeiam o seu trabalho como "continência", atribuindo a ele funções interventivas além da tarefa de receber, como a de alívio e catarse pela possibilidade de falar. Essa descrição se aproxima de uma concepção psicanalítica de escuta e utiliza o termo 'catarse' como 'descarga de afeto'.

No entanto, depois de descreverem o modo como está organizada a porta de entrada do serviço, os trabalhadores falam sobre concepções de entendimento do acolhimento e nesse momento aparecem definições como o atendimento aos que chegam sem agendamento prévio ou encaminhamento formal, utilizado para verificar a necessidade do usuário e a disponibilidade de atendê-la ou para dar conta de situações urgentes, escutando a queixa e entendendo o motivo da procura.

Também encontramos a idéia de que acolher é um modo de receber, com uma característica virtual (que não se materializa em um procedimento ou local delimitado), contínua (não só no momento de recepção) e que pode ser descrito como a qualidade de bem receber, de fazer com que a pessoa se sinta bem. 
Alguns discursos apontam ainda para a ansiedade relacionada ao acolhimento por sua característica imprevista que 'quebra' a rotina de atendimentos agendados, acarretando em encaminhamentos precoces.

A maioria distingue a prática de acolhimento da então nomeada triagem que por sua vez é descrita como uma prática que avalia, classifica e encaminha ou então como um procedimento técnico de entrevista que visa conhecer detalhadamente o usuário, coletando sua história (via anamnese) e descrevendo seus sintomas.

Essa distinção nos permite discutir o entendimento sobre as formas de escuta que distinguem tais concepções em sua origem.

Borges (2007), buscando diferenciar o método da clínica psicanalítica do método médico-psiquiátrico privilegia a escuta do 'novo', ou 'desconhecido' naquilo que o paciente diz. De um lado a autora aponta um procedimento que "visa dar ao médico a possibilidade de ver o que ele já aprendeu a ver" e de outro o psicanalista que "para poder permanecer no lugar de equívoco e de acolhimento, se visse obrigado a renunciar a querer aparecer como o que sabe mais sobre o outro que ele mesmo, o que é muitas vezes difícil e doloroso" (p. 205)

E sobre a ansiedade causada pela perspectiva do acolhimento ou a utilização, como descrito no caso da triagem, de métodos de coleta de dados podemos entender como ressalta a mesma autora no fragmento a seguir:

"O temor diante de algo não previsto, diante de uma intrusão perturbadora por parte do paciente, pode engendrar no médico (e em outros indivíduos) a busca de uma proteção e esta última pode ligar-se ilusoriamente ao contexto institucional que deveria reassegurá-la (as normas, a rotina, os manuais, etc)". (BORGES, 2007, p. 212)

Associando os documentos que definem a estratégia de acolhimento (no plano teórico e na proposta de implantação) com a caracterização encontrada no discurso dos trabalhadores, podemos traçar um paralelo que elucida as dificuldades e resistências ou mesmo a avaliação de sua eficiência. 
Sendo assim, podemos supor que enquanto conceito ou estratégia preconizada para garantir o acesso, os trabalhadores compreendem sua função e podem mesmo descrevê-la como de grande importância. No entanto, as práticas ainda se organizam de um modo distante ao proposto pela estratégia de acolher e podemos pensar, tendo em vista os últimos argumentos, que este funcionamento esteja apoiado em uma lógica que não suporta a imprevisibilidade da procura de fato espontânea, no momento em que é sentida como urgente pelo usuário, o que nos coloca frente ao próximo tópico de discussão, o que se debruça sobre as questões especificas da procura feita por adolescentes. 


\section{CONSIDERAÇÕES FINAIS}




\section{CONSIDERAÇÕES FINAIS}

Depois de discutir a formação para o trabalho como fonte de recursos para a prática que se encontra em transformação constante e a estratégia de acolhimento como privilegiada pra garantir o acesso, - enfrentando com isso as burocratizações que podem dificultar o contato com os serviços de saúde - pretendemos levantar a questão (a partir dos dados de análise ${ }^{12}$ e de reflexões teóricas) do uso que os adolescentes conseguem fazer dos serviços de saúde mental e pensar quais seriam ainda os principais entraves para que eles possam recorrer a essa alternativa no processo de seu desenvolvimento.

Percebemos, pelo discurso dos trabalhadores, que os critérios de inclusão no serviço, seja na recepção de adolescentes ou de qualquer outro que o procure, são complexos e na maior parte das vezes causam dúvida quanto a sua indicação precisa.

As questões mais referidas são as urgências (e seus maiores representantes são os casos de tentativa de suicídio), a relação com as instituições que fazem o encaminhamento, as características e condições do serviço, a gravidade do caso e a organização da rede de atenção.

As urgências são definidas como situações-limite, onde o serviço assume o papel de "apagar incêndio". Na maior parte das vezes essas situações já são encaminhadas por outros serviços como urgentes e com isso são recebidas com prioridade. Da mesma forma, outras situações ganham relevo pela relação de parceria estabelecida com outras instituições ou trabalhadores que as representam e são recebidas pela 'confiança' no encaminhamento de que se trata de um caso que

12 Para pensarmos os critérios de entrada, faremos referência aos eixos temáticos 'critérios de inclusão', 'caracterização do trabalho em equipe' e 'função das políticas que caracterizam o serviço. Quanto ao uso que os adolescentes conseguem fazer dos serviços de saúde mental e seus entraves, além dos itens já mencionados serão incluídas as 'reflexões sobre a ausência de adolescentes nos serviços de saúde'. 
"realmente necessita de atenção". Nesses dois casos o entendimento de urgência e prioridade é caracterizado por outros que não aquele que chega, o adolescente que fala, ou aquele que recebe, o trabalhador que o escuta. Trata-se de uma urgência 'objetivada' a fim de se transformar em critério de prioridade.

No caso das características do serviço, os trabalhadores colocam em xeque as condições que possuem para receber a demanda que chega, seja por limitações da estrutura do serviço, seja pela formação ou condição pessoal do trabalhador, restringindo a inclusão ao que está instituído no funcionamento do serviço ou aos instrumentos técnicos disponíveis para dar conta do caso. Também nessa perspectiva a demanda é limitada àquele que escuta e encontra pouca possibilidade de gerar espaço de criação a partir do que o demandante necessita ou deseja do serviço.

Quanto à gravidade, esta é relacionada aos prejuízos que o adolescente pode estar vivenciando em sua vida cotidiana, como não freqüentar a escola, não se relacionar com outros ou não circular pelo espaço social. Nesse aspecto, o conceito de saúde (mental) aparece como a possibilidade de circulação pelo espaço social e de manutenção das tarefas próprias ao adolescente, como freqüentar a escola e se relacionar com outros, o que não acontecendo indica uma ruptura com o estado saudável e leva ao trabalho de recuperá-lo.

No que se refere à rede de atenção, os critérios são enunciados como uma divisão de tarefas onde a cada serviço caberia certo tipo de demanda, relacionadas às questões acima descritas. Casos leves seriam direcionados e incluídos em serviços de atenção básica, casos complexos e de diagnóstico de gravidade caberiam aos serviços com maiores recursos. Urgências e emergências seriam recebidas, em um primeiro momento, pelo pronto socorro. Contudo, nessa divisão de tarefas são descritos "buracos" que acabam por gerar confusão e angústia no trabalhador que relata não saber o que fazer. Comumente nas entrevistas esse é o caso de questões intermediárias entre o "leve" e o "grave" que em outra configuração seriam destinados a serviços ambulatoriais, hoje praticamente inexistentes do ponto de vista formal. 
Esse "buraco", ou "não-lugar", identificado pelos trabalhadores na rede de serviços não seria próximo ao lugar subjetivo do adolescente na constituição social? Não seria o adolescente o representante comum da falta de lugar no instituído e dessa forma um "inaugurador" em potencial? No entanto, para isso seria necessária a possibilidade de criar, de escutar o novo.

No discurso da Saúde Pública, pautado no discurso da ciência, as prioridades e objetivos são comumente determinados previamente pelo estudo de necessidades e padrões que despontam no cenário social, o que dificultaria a abertura constante para demandas que estejam sempre em transformação. Colocando à disposição do adolescente meios aos quais ele possa recorrer, que levem em conta o seu desejo, a Saúde Pública estaria assumindo uma postura ética e "dessa forma, (...) poderia produzir um discurso que não seria o discurso da ordem, mas sim um discurso que daria alguma chance ao bem estar”. (REIS, 1993)

Não nos surpreende que, mesmo circunscrevendo as formas de chegada e as características especificas da procura de adolescentes, a maioria dos trabalhadores alegue que estes raramente chegam ao serviço e, nesse caso, o único que se diferencia é o programa PRÓ-ADOLESC, que tem a função de atender exclusivamente essa população.

Essa ausência dos adolescentes nos serviços de saúde (de saúde mental no caso) é elaborada por cada trabalhador de forma particular, mas que converge em temas semelhantes.

Muitos pensam que essa ausência se relaciona ao estigma que pode ser alcunhado aos usuários dos serviços de saúde mental ou mesmo à 'consulta' a profissionais que são diretamente relacionados a este campo como o médico psiquiatra e o psicólogo. Segundo esses profissionais, para os adolescentes, diferentemente dos adultos, freqüentar um equipamento de saúde mental é "depor contra", pois estes seriam apontados na escola ou na comunidade como "loucos" ou "problemáticos". 
Outra concepção passa pela distinção de características próprias dos adolescentes, nomeados como instáveis e refratários. Nesse caso, os adolescentes chegam ao serviço, mas não permanecem nele por dificuldades próprias de sua fase de vida. Também são denominados como contestadores das normas e com dificuldade de aprofundar suas questões, apontando para uma concepção de adolescência ainda predominantemente naturalizada, universal e patológica, distante de um olhar mais ampliado e contextualizado na construção social do discurso sobre este público.

Fonseca (2008), em sua recente pesquisa de doutorado que versa sobre a construção de sentidos sobre a adolescência por profissionais de saúde da Estratégia de Saúde da Família, aponta em suas conclusões que "muitos relatam que o adolescente não vem à unidade (não tem problemas de saúde) e não adere ao grupo. De certa forma, culpabilizam-no pelo fracasso de algumas tentativas de trabalho com este público". (FONSECA, 2008, p. 234)

Tais afirmações concordam com o discurso dos trabalhadores entrevistados, onde essas características mencionadas como próprias da adolescência são apontadas por alguns como as razões para que eles não busquem ou não permaneçam nos serviços de saúde, no entanto, para outros é fundamental que um serviço se adapte às necessidades de sua população, o que esbarra na dificuldade de delimitar quais seriam as necessidades dos adolescentes.

Como discutimos anteriormente, talvez as necessidades de saúde só possam ser dimensionadas quando se relacionam com a demanda, ou seja, através dos "pedidos" dirigidos à instituição. Apesar de podermos contar com recursos de pesquisas epidemiológicas ou questionários de morbidade, como sugere Campos (1969), partimos do pressuposto de que a demanda carrega em si algo da necessidade e que cabe ao 'espectador'13 observar as nuances dessa demanda antes de tentar responder a ela.

\footnotetext{
${ }^{13}$ Como denomina Bezerra Junior, citado no capítulo sobre 'necessidade e demanda' na introdução deste trabalho, se referindo "aquele que se encontra diante da procura e que se interessa em observar suas determinações históricas, sociais e ideológicas que escapariam à consciência do paciente".
} 
Marçola e Marques (2005) se propõem a refletir acerca da associação entre a demanda própria do adolescente frente a uma organização que se disponha a recebêlos de forma premente a sua procura e apontam:

"Necessitados, muitas vezes confusos em suas demandas e ainda distantes de seus desejos, encontram-se eles no Plantão-Recepção. $\dot{E}$ um desafio que nos provocou percorrer pelo instituído, o Plantão-Recepção, de onde vimos emergir o não-instituído, a demanda, propiciando ver a especificidade que pode assumir a relação terapêutica. Seria este procedimento já terapêtico?" (MARÇOLA e MARQUES, 2005, p. 3)

Sob o ponto de vista dessas autoras, a forma de recepção na qual se organiza o serviço seria da ordem do instituído enquanto a demanda trazida pelos usuários revelaria o não-instituído ou, como nomeado anteriormente, o novo, o desconhecido.

No entanto, partindo das reflexões que temos proposto até este momento, seria mesmo a demanda percebida como algo da ordem do não-instituído? Se pensarmos que os serviços funcionam em sua maioria na lógica da oferta, e não da demanda, não estaríamos próximos de concluir que os critérios de inclusão se fundamentam ainda no 'encaixe' de certas demandas ao que o serviço tem para oferecer?

Os adolescentes, do ponto de vista dos trabalhadores entrevistados, só buscam os serviços de saúde mental quando precisam pontualmente deles (para uma questão específica) e não a fim de prevenirem possíveis agravamentos de seus problemas circunstanciais, como pode ser o desejo de alguns. Nesse caso, a compreensão é de que eles, por um lado, encontram alternativas diferentes quando se trata da necessidade de informação (como os meios de comunicação), mas, por outro lado, de que fazem um uso 'descomprometido' do serviço por não conseguirem (ou não desejarem) aderir às normas que ele, o serviço, condiciona para incluir os usuários.

Fonseca (2008), também encontra na fala dos trabalhadores de saúde a dificuldade em, percebendo as necessidades do adolescente, transformá-las em potencialidades de trabalho, pois segundo eles (trabalhadores), faltam instrumentos 
para lidar com o adolescente que possui características e questões diferenciadas de outros públicos.

A questão levantada pelos profissionais escutados no trabalho de pesquisa referido, quanto à necessidade de uma formação especifica requerida para o trabalho com o adolescente, afirma ainda a apreensão das questões de saúde na adolescência pela via do patológico, necessitando de treinamento especifico como acontece com a diabete ou a hipertensão.

Voltando ainda à citação de Marçola e Marques, vemos que para além da diferenciação do instituído e não-instituído, o encontro com a demanda produz questionamentos a respeito da relação usuário-trabalhador e da possibilidade terapêutica que ele carrega como potencialidade. A partir desse ponto de vista, levanta-se a questão da participação do adolescente (sendo considerado como sujeito de direito e de desejo), da possibilidade de dar voz a suas necessidades e com isso transformar de forma democrática o serviço de saúde para poder usufruir dele. Este seria um ganho político, mas não seria também terapêutico?

Esse aspecto, colocado em relevância, nos faz retornar aos pressupostos da estratégia de acolhimento como forma de organização da porta de entrada que privilegia a escuta da demanda e reconhece nela uma possibilidade resolutiva.

Podemos concluir que adolescentes e serviços de saúde funcionam em lógicas diferentes e que esse desencontro muitas vezes impossibilita o reconhecimento dos serviços de saúde mental como recursos possíveis aos quais possam recorrer em caso de necessidade, o que pode causar, em movimento correspondente, a falta de planejamento de ações voltadas a eles com base no discurso de que eles não demandam nada dos serviços de saúde. Ou seja, o discurso dos trabalhadores sobre a escassez da procura de adolescentes corre o risco de rumar para uma correspondente diminuição de ofertas ao invés do questionamento sobre a peculiaridade das demandas dessa população e de formas alternativas de recebê-las. 


\section{REFERÊNCIAS BIBLIOGRÁFICAS}




\section{REFERÊNCIAS BIBLIOGRÁFICAS}

Alberti S. The Adolescent and it's Pathos. Psicol. USP, São Paulo, v. 13, n.2, 2002.

Amarante P. Saúde mental e atenção psicossocial. Rio de Janeiro: Editora Fiocruz, 2007.

Ayres JRCM. Sujeito, intersubjetividade e práticas de saúde. Ciênc. saúde coletiva [online]. 2001, v. 6, n. 1, pp. 63-72.

Bastos ABFR, Álvarez K, Ribeiro MMC. Porta de entrada para adolescentes autistas e psicóticos numa instituição de saúde mental. Psicologia Ciência e Profissão, v. 21, pp. 290-303, 2007.

Bernardes AG, Guareschi NMF. Identidade e diferenças: constituição de trabalhadores na saúde mental. Athena Digital, Espanha, v. 2, p. 01-17, 2002.

Bezerra Jr B. Considerações sobre terapêuticas ambulatoriais em Saúde Mental. In: Tundis AS, Costa NR. (orgs.) Cidadania e Loucura. Políticas de Saúde Mental no Brasil, Petrópolis, Vozes/ABRASCO, 8. ed. 2007.

Birman J. A physis da saúde coletiva. Physis: Rev. Saúde Coletiva, Rio de Janeiro, 15(Suplemento):11-16, 2005

Birman J. A psiquiatria como discurso da moralidade. Rio de Janeiro: Edições Graal, 1978.

Borges SMN. Por uma clínica que a psicanálise nos ensina. In: Tundis AS, Costa NR. (orgs.) Cidadania e Loucura. Políticas de Saúde Mental no Brasil, Petrópolis, Vozes/ABRASCO, 8. ed. 2007.

Brandão HN. Introdução à análise do discurso. $2^{\mathrm{a}}$ ed. rev. Campinas: Editora UNICAMP, 2004.

Brasil, Ministério da Saúde. SAS/DAPE/DAB. Coordenações de Saúde Mental e de Gestão da Atenção Básica. Saúde mental na atenção básica: o vínculo e o diálogo necessários. Brasília, 2003

Brasil. Ministério da Saúde. Secretaria de Atenção à Saúde. Área de Saúde do Adolescente e do Jovem. Marco legal: saúde, um direito de adolescentes. Brasília: Ministério da Saúde, 2005a. 
Brasil. Ministério da Saúde. Secretaria de Atenção à Saúde. Departamento de Ações Programáticas Estratégicas. Caminhos para uma política de saúde mental infantojuvenil. Série B - Textos Básicos em Saúde. Brasília, 2005b.

Brasil. Ministério da Saúde. Secretaria de Atenção à Saúde/DAPE-DAB. Saúde mental na atenção básica: o vínculo e o diálogo necessários [site na Internet]. [acessado 2009 maio 8]. Disponível em: http://portal.saude.gov.br/portal/arquivos/pdf/diretrizes.pdf

Calazans R, Bastos A. Urgência subjetiva e clínica psicanalítica. Rev. latinoam. psicopatol. fundam. [online], vol.11, n.4, pp. 640-652, 2008.

Calligaris C. A Adolescência. São Paulo; PubliFolha; 2000 (Folha Explica).

Campos CMS, Soares CB. A produção de serviços de saúde mental: a concepção de trabalhadores. Ciência e Saúde Coletiva. 2003; 8 (2): 621-628.

Campos O. O estudo da demanda e das necessidades e sua importância para planejamento de saúde. Rev. Saúde públ., São Paulo, v. 3, n. 1, pp. 79-81, jun. 1969.

Canguilhem G. O normal e o patológico. Rio de Janeiro: Editora ForenseUniversitária, 1978.

Carvalho SR, Campos GWS. Modelos de atenção à saúde: organização de equipes de referência na rede básica da Secretaria Municipal de Saúde de Betim, Minas Gerais. Cadernos de Saúde Pública, Rio de Janeiro, v. 16, n. 2, p. 507-515, 2000.

Cerqueira L. Psiquiatria social: problemas brasileiros de saúde mental. Rio de Janeiro: Livraria Atheneu, 1989.

Claro LBL et al. Adolescentes e suas relações com serviços de saúde: estudo transversal em escolares de Niterói, Rio de Janeiro, Brasil. Cad. Saúde Pública, Rio de Janeiro, 22(8):1565-1574, ago, 2006.

Costa JF. História da psiquiatria no Brasil: um corte ideológico. 5. ed. rev. Rio de Janeiro: Garamond, 2007.

Deslandes, SFA Construção do Projeto de Pesquisa. In: MINAYO, M. C. S. Pesquisa Social. Teoria Método e Criatividade. 17 ed. Petrópolis, RJ: Vozes, 2000.

Duarte LFD. A outra saúde: mental, psicossocial, físico, moral? In: Alves, PC. Saúde e doença: um olhar antropológico / org. Alves PC, Minayo MCS. Rio de Janeiro; Fiocruz, 1994.

Elias PE. PAS: um perfil neoliberal de gestão de sistema público de saúde. Estud. Av. [online]. 1999, vol. 13, n. 35, pp. 125-137.

Elias PE. PAS: um perfil neoliberal de gestão de sistema público de saúde. Estud. av. [online]. 1999, vol.13, n.35. 
Ferreira AAL. Da nau dos loucos ao grande exclausuramento: uma história das histórias foucaultianas sobre a loucura. Cadernos de Saúde Coletiva. Rio de Janeiro, 2001; 9 (1): 69-81.

Ferreira $\mathrm{AB}$ de H. Dicionário da Língua Portuguesa. Rio de Janeiro: Editora Nova Fronteira, 1980.

Fonseca DC. Os profissionais da Estratégia da Saúde da Família (ESF) e a construção de sentidos sobre a adolescência. São Paulo, 2008. [Tese de Doutorado em Psicologia Social - Pontifícia Universidade Católica de São Paulo - PUC-SP]

Franco TF, Merhy EE. A produção imaginária da demanda. In: Pinheiro R, Matos RA. Produção Social da Demanda, IMS/UERJ-ABRASCO-LAPPIS, Rio de Janeiro, 2005.

Freud S. O mal-estar na civilização (1929). Edição Standard Brasileira das Obras Completas de Sigmund Freud. Rio de Janeiro: Imago; 1969. v. XXI; p. 73-171.

Goffman E. Manicômios, prisões e conventos. São Paulo: Perspectiva, 1974.

Grossman E, Cardoso MHC. As bases conceituais dos documentos oficiais de atenção à saúde do adolescente. Revista Brasileira de Crescimento e Desenvolvimento Humano, São Paulo, 7(2), 1997.

Guagliardi, EC. Aonde levar as crianças - sobre um lugar para atendê-las. Jornal Brasileiro de Psiquiatria. 1990; 41 (3): 137-143.

Guerra AMC. A psicanálise no campo da saúde mental infanto-juvenil. Psyché, janjun, ano/vol. IX, número 15, Universidade São Marcos, São Paulo, 2005, pp. 139154.

Iunes RF. Demanda e demanda em saúde. In: Piola SF, Vianna SM. Economia da saúde: conceito e contribuição para a gestão da saúde. Brasília, Instituto de Pesquisa Econômica Aplicada - IPEA, 1995. P. 99-122, tab.

Lancetti A, Amarante P. Saúde mental e saúde coletiva. In: Campos GW de S et al. Tratado de saúde coletiva. São Paulo: Hucitec; Rio de Janeiro: Ed. Fiocruz, 2006.

Lescher AD, Grajcer B, Bedoian G, Azevedo LM, Silva LN da, Pernambuco MCA, Carneiro Júnior N. Crianças em situação de risco social: limites e necessidades da atuação do profissional da saúde. São Paulo; Secretaria Municipal da Saúde; set. 2004. 74 p. graf. Disponível em: http://www.projetoquixote.epm.br/publicacao.pdf

Lesourd S. A construção adolescente no laço social. Tradução de Lucy Magalhães. Rio de Janeiro: Vozes, 2004.

Levcovitz S, Oliveira R, Tenório FA. A importância estratégica dos dispositivos de recepção. Cad. IPUB, v.6, n.17, p. 7-14, 2000. 
Lopes RE. Cidadania, políticas públicas e terapia ocupacional no contexto das ações de saúde mental e saúde da pessoa portadora de deficiência no Município de São Paulo. Campinas, 1999. [Tese de doutorado - Faculdade de Educação da Universidade Estadual de Campinas].

Maingueneau D. Novas tendências em análise do discurso. Campinas: Pontes, 1993.

Mângia EF et al. Acolhimento: uma postura, uma estratégia. Revista de Terapia Ocupacional da Universidade de São Paulo. 2002; v. 13, n. 1, 15-21.

Marçola MA, Marques CS. A porta de entrada para o atendimento clínico na instituição pública: adolescentes repletos de querer, mas nem tanto assim.. In: Simpósio Internacional do Adolescente, 2., 2005, São Paulo.

Merhy EE, Onoko HT. Agir em saúde: um desafio para o público. 1. ed. São Paulo: HUCITEC, 1997. v. 1.

Minayo MCS. O desafio do conhecimento: pesquisa qualitativa em saúde. São Paulo: Hucitec, 2004.

Ministério da Saúde. Caminhos para uma política de saúde mental infanto-juvenil. Série B. Textos Básicos em Saúde. Brasília, 2005.

Miranda CAC. Da polícia médica à cidade higiênica. Caderno de Extensão da UFPE, Recife, v. 1, n. 1, p. 7-20, 1998.

Motta JIJ, Buss P, Nunes TCM. Novos desafios educacionais para a formação de recursos humanos em saúde. Olho Mágico, Londrina, v.8, n.3, p.4-8, set./dez.2001.

Onocko Campos R. O encontro trabalhador-usuário na atenção à saúde: uma contribuição da narrativa psicanalítica ao tema do sujeito na saúde coletiva. Ciência e Saúde Coletiva. 2005; 10 (3): 573-583.

Orlandi EP. A linguagem e seu funcionamento: as formas do discurso. Campinas: Pontes, 1987.

Orlandi EP. Análise do discurso: princípios e procedimentos. $7^{\mathrm{a}}$ edição, Campinas: Pontes, 2007.

Pacheco e Silva AC. Higiene mental: conceito, generalidades, tendências modernas e campo de aplicação. São Paulo: Universidade de São Paulo, 1952.

Pereira MEC. A saúde mental e a razão sanitária. Rev. Latinoam. Psicopat. Fund., São Paulo, v. 11, n. 3, p. 509-513, setembro 2008.

Peres F. Adolescência: em busca dos sujeitos sociais. São Paulo, 1995. [Tese de Doutorado - Faculdade de Saúde Pública da Universidade de São Paulo]. 
Ramminger T. Trabalhadores de saúde mental: reforma psiquiátrica, saúde do trabalhador e modos de subjetivação nos serviços de saúde mental. Porto Alegre, 2005. [Tese de Mestrado - Instituto de Psicologia - Universidade do Rio Grande do Sul].

Reis AOA. O discurso da saúde pública sobre a adolescente grávida: avatares. São Paulo, 1993. [Tese de Doutorado - Faculdade de Saúde Pública da Universidade de São Paulo].

Resende H. Política de saúde mental no Brasil: uma visão histórica. In: Tundis AS, Costa NR. (orgs.) Cidadania e Loucura. Políticas de Saúde Mental no Brasil, Petrópolis, Vozes/ABRASCO, 8. ed. 2007.

Ribeiro PRM. Saúde mental no Brasil. São Paulo: Arte \& Ciência, 1999.

Rocha D, Deusdará B. Análise de Conteúdo e Análise do Discurso: aproximações e afastamentos na (re)construção de uma trajetória. Alea. Estudos Neolatinos, v. 17, p. 305-322, 2005.

Rosa, MD. Adolescência: da cena familiar à cena social. Psicol. USP, São Paulo, v. 13, n. 2, 2002.

San Martín H, Pastor V. Economía de la salud. Madrid: Interamericana McGrawHill, 1989.

São Paulo [Estado]. Comissão de Cuidados à Saúde Mental de Crianças e Adolescentes. Política de atenção à saúde mental da infância e adolescência - uma proposta de organização da atenção. São Paulo, 2002.

São Paulo [Município]. Secretaria Municipal de Saúde de São Paulo. Área Técnica de Saúde da Criança e do Adolescente. PRO-ADOLESC: Programa de Atenção à Saúde do Adolescente. São Paulo: Secretaria Municipal de Saúde, 2006.

Scavone L. O trabalho das mulheres pela saúde: cuidar, curar, agir. In: Villela W; Monteiro S. (Org.). Gênero e Saúde - Programa Saúde da Família em Questão. 1 ed. São Paulo: ABRASCO/UNFPA/ Arbreit Factor, 2005, p. 99-109.

Schraiber LB. Pesquisa qualitativa em saúde: reflexões metodológicas do relato oral e produção de narrativas em estudo sobre a profissão médica. Rev. Saúde Pública, São Paulo, v. 29, n. 1, fev. 1995.

Silva ATMC, Barros S, Oliveira MAF de. Políticas de saúde e de saúde mental no Brasil: a exclusão/inclusão social como intenção e gesto. Revista da escola de Enfermagem da USP, v. 36, pp. 04-09, 2002.

Silveira DP. Sofrimento psíquico e serviços de saúde mental: uma cartografia da produção do cuidado de saúde mental na atenção básica de saúde. Rio de Janeiro, 2003. [Dissertação de Mestrado - Escola Nacional de Saúde Pública] 
Singer P et al. Prevenir e curar: o controle social através dos serviços de saúde. Rio de Janeiro: Editora Forense-Universitária, 1978.

Sonenreich C, Estevão G, Silva Filho LMA. Ensaios sobre modos de conceber a patologia mental. Temas: teoria e prática da psiquiatria. 2004; 66-67: 60-115.

Stamato MIC. Protagonismo juvenil: uma práxis sócio-histórica de ressignificação da juventude. São Paulo, 2008. [Tese de Doutorado em Psicologia Social - Pontifícia Universidade Católica de São Paulo - PUC-SP]

Telles HPRS. Infância e saúde mental: teoria, clínica e recomendações para políticas públicas. São Paulo, 2006. [Tese de Mestrado - Faculdade de Saúde pública da Universidade de São Paulo].

Vicentin MCG. Infância e adolescência: uma clínica necessariamente ampliada. Rev. Ter. Ocup. Univ. São Paulo, v. 17, n. 1, p. 10-17, jan./abr. 2006. 
ANEXOS 


\section{ANEXO 1 \\ TERMO DE CONSENTIMENTO LIVRE E ESCLARECIDO}

Título do Projeto: "Desvelando critérios utilizados por profissionais para a inclusão de adolescentes em serviços públicos de saúde mental"

Pesquisador Responsável: Natália Areias Gomes - Psicóloga (CRP 06/74251), mestranda da Faculdade de Saúde Pública da Universidade de São Paulo (FSP-USP), sob a orientação da Prof ${ }^{a}$ Dra. Néia Schor, titular do departamento de Saúde Materno-Infantil.

Este projeto tem o objetivo de caracterizar e analisar critérios que norteiam a inclusão de adolescentes em serviços públicos de atenção à saúde mental a partir do discurso dos profissionais que os recebem, identificando concepções acerca do sofrimento psíquico e caracterizando a prática de acolhimento que se estabelece na seleção de pacientes.

Para tanto serão realizadas entrevistas abertas, com aproximadamente uma hora de duração, durante as quais o profissional entrevistado será convidado a falar sobre o tema em questão, sempre visando alcançar os objetivos desta pesquisa.

A participação neste estudo permitirá que a pesquisadora utilize as informações dadas sem que haja identificação do nome do entrevistado e este tem a liberdade de se recusar a participar e ainda se recusar a continuar participando em qualquer fase da pesquisa, sem qualquer prejuízo no desenvolvimento de suas funções. Sempre que quiser poderá pedir mais informações sobre a pesquisa através do telefone da pesquisadora, do Comitê de Ética em Pesquisa da Faculdade de Saúde Pública da Universidade de São Paulo e/ou do Comitê de Ética em Pesquisas da Secretaria Municipal da Saúde de São Paulo.

De acordo com os seguintes princípios:

Autonomia: Considero preservada minha participação como voluntário(a), sem coerção pessoal ou institucional, dando minha permissão para ser entrevistado e para esta entrevista ser gravada e transcrita. Estou ciente de que sou livre para recusar a dar repostas a determinadas questões durante a entrevista, retirar meu consentimento e terminar minha participação a qualquer tempo, bem como terei a oportunidade para perguntar sobre qualquer questão que eu desejar, e que todas deverão ser respondidas pelo pesquisador a meu contento.

Beneficência: Estou ciente de que poderá não haver benefícios diretos ou imediatos para mim enquanto entrevistado deste estudo. Estou ciente de que também poderá não haver benefícios diretos e imediatos para minhas atividades profissionais ou para a instituição onde trabalho, mas sei que poderá haver alguma mudança positiva na abordagem de problemas de saúde mental após outros profissionais e outras instituições tomarem conhecimento das conclusões desta pesquisa.

Não-maleficência: Estou ciente de que estarão garantidas a não invasão de minha privacidade. Sei que, além do pesquisador, alguns outros colegas pesquisadores, especialistas da área, poderão conhecer trechos do conteúdo para discussão dos 
resultados, mas meu nome será omitido e estas pessoas estarão sempre submetidas às normas do sigilo profissional. A pesquisa estará disponível para todos quando estiver concluído o estudo, inclusive para apresentação em encontros científicos e publicação em revistas especializadas, podendo conter citações literais da entrevista, mas sempre de modo anônimo e evitando a identificação do informante. Finalmente, estou ciente de que serei respeitado (a) quanto a não ter tocados aspectos de foro íntimo, a não ser quando for de minha concordância em abordá-los.

Declaro estar ciente do exposto e desejar participar da pesquisa.

São Paulo, de de

Nome do sujeito:

Assinatura:

Eu, Natália Areias Gomes, declaro que forneci todas as informações referentes ao projeto ao participante.

Data:

\section{Telefones e Endereços:}

Pesquisadora: Natália Areias Gomes. Av. Dr. Arnaldo, $715-2^{\circ}$ Andar - Cerqueira César. São Paulo. Fone: 3061-7703 - e-mail: natalia.areias@usp.br

Comitê de Ética em Pesquisa da Faculdade de Saúde Pública da USP: Av. Dr. Arnaldo, 715 - Térreo - Cerqueira César. São Paulo. Fone: 3061-7779/7742 - e-mail: coep@fsp.usp.br

Comitê de Ética em Pesquisas da Secretaria Municipal da Saúde de São Paulo: Rua General Jardim, $36-2^{\circ}$ andar - Fone: 3218-4043 - e-mail: smscep@prefeitura.sp.gov.br 